
COLUMN ION EXCHANGE PROJECT

OCTOBER 2010

Savannah River National Laboratory

Savannah River Nuclear Solutions

Aiken, SC 29808

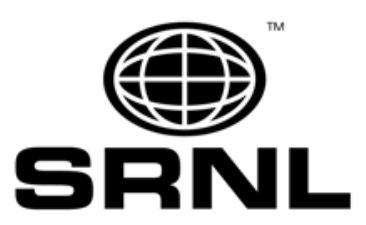


DISCLAIMER

This report has been authored by Savannah River Nuclear Solutions,
LLC under Contract No. DE-AC09-08SR22470 with the U.S.
Department of Energy. Specifically, the research was supported by a
Work for Others (WFO-08-014) with Washington Safety
Management Solutions LLC. The United States Government retains
and the publisher, by accepting this article for publication,
acknowledges that the United States Government retains a non-
exclusive, paid-up, irrevocable, worldwide license to publish or
reproduce the published form of this work, or allow others to do so, for
United States Government purposes.


Key Words:

Thermal Modeling Heat

Transfer Analysis Crystalline Silicotitanate IX Column

High Level Waste Tank

Retention:

Permanent

\title{
THERMAL MODELING ANALYSIS OF CST MEDIA IN THE SMALL COLUMN ION EXCHANGE PROJECT
}

\author{
Si Young Lee \\ William D. King
}

OCTOBER 2010

Savannah River National Laboratory

Savannah River Nuclear Solutions

Savannah River Site

Aiken, SC 29808 


\section{REVIEWS AND APPROVALS}

S. Y. Lee, Author, Applied Computational Engineering \& Statistics Group Date

W. D. King, Coauthor, Adv. Characterization \& Process Group Date

$\overline{\text { F. G. Smith, III, Reviewer, Process Modeling \& Computational Chemistry Group Date }}$

$\overline{\text { P. L. Lee, Manager, Applied Computational Engineering \& Statistics Group Date }}$

S. J. Hensel, Manager, Computational Engineering \& Sciences Section Date

F. M. Pennebaker, Manager, Adv. Characterization \& Process Group Date

T. H. Huff, Customer, SRR Engineering

Date 


\section{TABLE OF CONTENTS}

LIST OF FIGURES ............................................................................................. iv

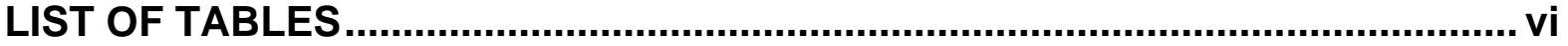

LIST OF ACRONYMS ...................................................................................... vii

1.0 EXECUTIVE SUMMARY .......................................................................... 1

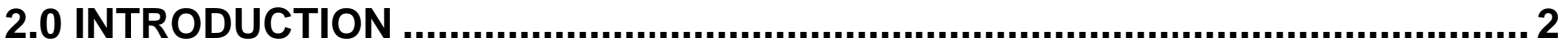

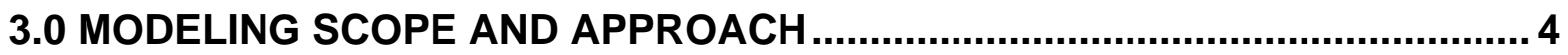

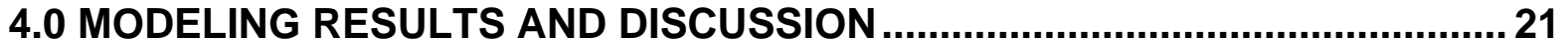

4.1 In-Column Thermal Modeling Results.................................................... 22

4.2 In-Tank Thermal Modeling Results..................................................... 32

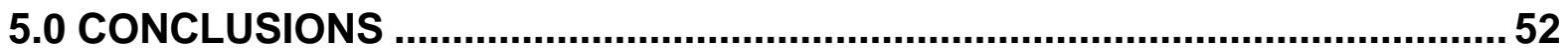

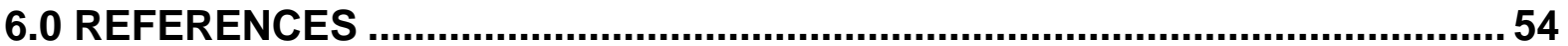




\section{LIST OF FIGURES}

Figure 1. Baseline modeling domain for the ion-exchange column with CST media. 3

Figure 2. Initial baseline three-dimensional modeling boundary for in-tank calculations in the Tank 41 facility.............................................................. 4

Figure 3. Two-dimensional computational mesh used for the in-column modeling

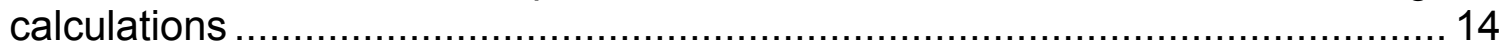

Figure 4. Natural convection heat transfer correlation available in the literature showing the conservatism imbedded in the present heat transfer analysis ....... 14

Figure 5. Forced convection correlation available in the literature demonstrating the range of convective heat transfer through the column water cooling system..... 15

Figure 6. Sensitivity results associated with numerical energy residual showing that approximately 8,100 meshes are sufficient for the present analysis ................ 15

Figure 7. In-tank column modeling geometry for Case 1 ................................... 19

Figure 8. In-tank column modeling geometry for Case 2 ................................. 19

Figure 9. Tank interior computational domain used for the in-tank modeling showing

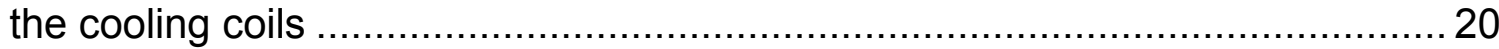

Figure 10. Tank interior computational meshes used for the in-tank modeling .......20 20

Figure 11. Computational domains for the hemispherical mound and the flat layer formed by CST accumulation on the tank floor ........................................... 21

Figure 12. Steady-state temperature distributions for the ion-exchange column with wet CST media under baseline conditions .............................................. 24

Figure 13. Steady-state column temperature profile along the radial line A-A' for stagnant wet CST media with active and inactive coolant systems ..................25

Figure 14. Transient maximum column temperatures for stagnant, wet CST media with active and inactive coolant systems ............................................... 26

Figure 15. Transient responses of maximum column temperatures to the inadvertent loss of process fluid with active internal and external cooling systems

Figure 16. Comparison of transient responses of maximum column temperatures with and without active cooling for the dry column case ............................... 27

Figure 17. Comparison of temperature distributions between dry and wet CST columns with inactive internal and external cooling ....................................28

Figure 18. Comparison of temperatures along the radial distance A-A' between the active and inactive coolant systems for the dry column case...........................29

Figure 19. Transient temperatures observed at two observation points located at the top and bottom surfaces of the hemispherical mound formed under Riser $\mathrm{G}$ of

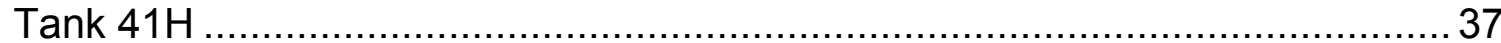

Figure 20. Transient snapshots for fluid flow patterns and temperature distributions

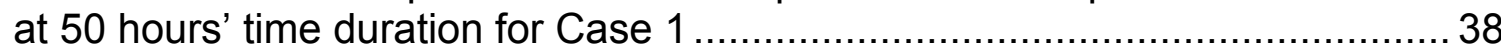

Figure 21. Steady-state flow patterns and temperature distributions for the dispersed CST layer with 1.7-in thickness ..................................................... 39

Figure 22. Transient temperatures for three different unground CST volumes at two observation points located at the top and bottom surfaces of a hemispherical mound formed under Riser $\mathrm{G}$ of Tank $41 \mathrm{H}$ 
Figure 23. Max. temperatures at the tank bottom surface of the unground CST mound formed under Riser $\mathrm{G}$ of Tank $41 \mathrm{H}$ for different CST mound heights .... 43

Figure 24. Tank bottom temperatures for 450 gallon cylindrical unground CST mound with 6-in height located under the Riser G

Figure 25. Tank bottom temperatures for 4200 gallon cylindrical unground CST mound with 6-in height located under the Riser G

Figure 26. Comparison of temperatures between the models with and without heat transfer through the tank bottom for 12-in cylindrical pancake mound .............. 47

Figure 27. Uniform and non-uniform ground CST packings .............................. 47

Figure 28. Maximum temperatures at the tank bottom surface of ground and unground cylindrical CST mounds formed under Riser G of Tank $41 \mathrm{H}$ with and without heat transfer through the tank bottom

Figure 29. Comparison of fluid flow patterns at the vertical plane surface crossing the hemispherical and cylindrical ground CST mounds under the same color scale

Figure 30. Comparison of temperature distributions at the vertical plane crossing the hemispherical and cylindrical ground CST mounds under the same color scale 51 


\section{LIST OF TABLES}

Table 1. Baseline modeling conditions used for the heat transfer analysis of the ion

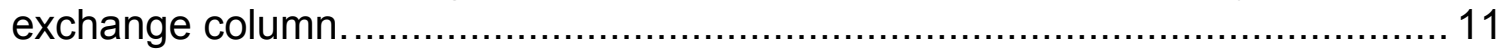

Table 2. Material and thermal properties for heat transfer calculations of the CST,

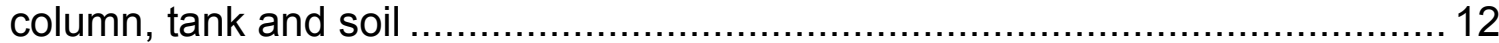

Table 3. Modeling cases used for the in-column analysis ................................... 13

Table 4. Heat source terms for the baseline column shown in Fig. 1................... 13

Table 5. Comparison of the two initial in-tank analysis cases with adiabatic floor

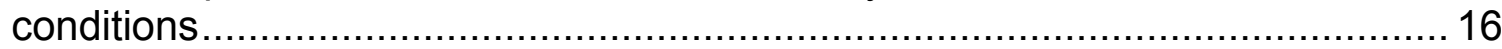

Table 6. Steady-state maximum column temperatures for various conditions for the

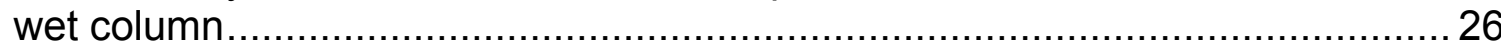

Table 7. Steady-state maximum column temperatures for various conditions ........ 30

Table 8. Additional steady-state maximum column temperatures for the dry column case with and without coolant air flow................................................... 30

Table 9. Steady-state maximum column temperatures for different ambient temperature and thermal loadings with active engineered cooling …..............31

Table 10. Steady-state maximum column temperatures for different ambient and coolant water temperatures with active engineered cooling.............................31

Table 11. Steady-state maximum column temperatures for various column operating conditions without engineered cooling ……................................ 32

Table 12. Summary results for the initial in-tank calculations ............................. 40

Table 13. Summary results for the in-tank calculations for Case 2 with varying liquid

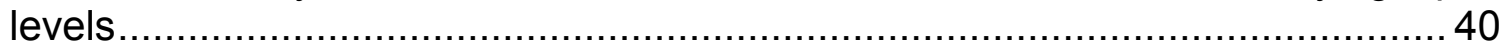

Table 14. In-tank calculational results for the hemispherical mound.....................42 42

Table 15. In-tank calculational results for different unground CST mound shapes . 42

Table 16. In-tank calculation results for 6 -in high cylindrical mounds with different

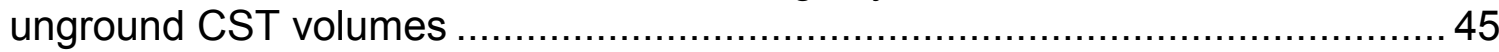

Table 17. Quantitative comparison of maximum tank bottom surface temperatures with and without heat transfer for different cylindrical, unground CST mound heights

Table 18. Quantitative comparison of maximum tank bottom surface temperatures with and without floor heat transfer for cylindrical mounds with original and ground CST particulates

Table 19. Quantitative comparison of maximum tank bottom surface temperatures with and without heat transfer for different ground, cylindrical CST mound heights

Table 20. Quantitative comparison of maximum tank wall temperatures for the hemispherical and cylindrical mounds for 450 gallon mounds of ground and

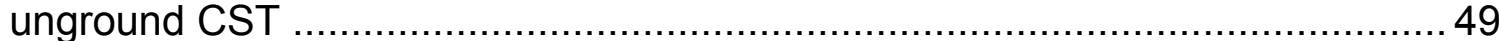

Table 21. Heat distribution from the ground CST mound ...................................52

Table 22. In tank results for the flat layer configuration consisting of mixtures of ground ground CST, unground MST, and sludge 


\section{LIST OF ACRONYMS}

\begin{tabular}{|c|c|}
\hline$A_{w}$ & Wall surface area of bed column \\
\hline${ }^{\circ} \mathrm{C}$ & Degree Centigrade (or Celsius) \\
\hline C & Constant \\
\hline CFD & Computational Fluid Dynamics \\
\hline $\mathrm{C}_{\mathrm{p}}$ & Specific heat $(\mathrm{J} / \mathrm{kg}-\mathrm{K})$ \\
\hline d & Wall thickness $(\mathrm{m})$ \\
\hline $\mathrm{D}$ & Column diameter $(\mathrm{m})$ \\
\hline$g$ & Gravity $\left(\mathrm{m} / \mathrm{sec}^{2}\right)$ \\
\hline $\mathrm{Gr}$ & Grashof number $\left(=\frac{g \rho^{2} \beta(\Delta T) L^{3}}{\mu^{2}}\right)$ \\
\hline HLW & High Level Waste \\
\hline $\mathrm{hr}$ & Hour \\
\hline $\mathrm{h}_{\mathrm{w}}$ & Wall heat transfer coefficient (watts $/ \mathrm{m}^{2}-\mathrm{K}$ ) \\
\hline$i$ & Enthalpy $(\mathrm{J} / \mathrm{kg})$ \\
\hline in & Inch $(=0.0254 \mathrm{~m})$ \\
\hline$k_{b, \text { eff }}$ & Effective thermal conductivity for column bed (W/m-K) \\
\hline$k_{w}$ & Thermal conductivity for the column wall $(\mathrm{W} / \mathrm{m}-\mathrm{K})$ \\
\hline $\mathrm{L}$ & Length (m) \\
\hline $\mathrm{m}$ & Meter \\
\hline $\min$ & Minute \\
\hline MST & Monosodium Titanate \\
\hline OD & Outer diameter \\
\hline q"” & Volumetric heat source for the bed column $\left(\mathrm{W} / \mathrm{m}^{3}\right)$ \\
\hline$q_{w} "$ & Wall heat flux $\left(\mathrm{W} / \mathrm{m}^{2}\right)$ \\
\hline$r$ & Geometrical radius $(\mathrm{m})$ \\
\hline $\mathrm{R}$ & Column inner radius $(\mathrm{m})$ \\
\hline $\mathrm{t}$ & Time (year or sec) \\
\hline$t_{\text {air }}$ & Air temperature $\left({ }^{\circ} \mathrm{C}\right)$ \\
\hline $\mathrm{T}$ & Temperature (K) \\
\hline$\Delta \mathrm{T}$ & Temperature difference $\left(\mathrm{K}\right.$ or $\left.{ }^{\circ} \mathrm{C}\right)$ \\
\hline $\mathrm{V}_{\mathrm{b}}$ & Bed volume $\left(\mathrm{m}^{3}\right)$ \\
\hline W or watts & Power wattage $(\mathrm{J} / \mathrm{sec})$ \\
\hline$x, y, z$ & Three coordinate system for the computational domain shown Fig. 1 \\
\hline$\rho$ & Density $\left(\mathrm{kg} / \mathrm{m}^{3}\right)$ \\
\hline$\beta$ & Volumetric coefficient of thermal expansion $\left(\mathrm{K}^{-1}\right)$ \\
\hline$\theta$ & Nondimensional temperature w.r.t ambient temperature \\
\hline$\mu$ & Dynamic viscosity $(\mathrm{kg} /(\mathrm{m}-\mathrm{sec}))$ \\
\hline$\varepsilon$ & Bed porosity \\
\hline s or sec & Second \\
\hline SCFM & Standard cubic feet per minute $\left(\mathrm{ft}^{3} / \mathrm{min}\right)$ \\
\hline SCIX & Small Column Ion Exchange \\
\hline SRNL & Savannah River National Laboratory \\
\hline SRS & Savannah River Site \\
\hline
\end{tabular}




\subsection{EXECUTIVE SUMMARY}

Models have been developed to simulate the thermal characteristics of Crystalline Silicotitanate (CST) ion exchange media fully loaded with radioactive cesium in a column configuration and distributed within a waste storage tank. This work was conducted to support the Small Column lon Exchange (SCIX) program which is focused on processing dissolved, high-sodium salt waste for the removal of specific radionuclides (including Cs-137, Sr-90, and actinides) within a High Level Waste (HLW) storage tank at the Savannah River Site. The SCIX design includes CST columns inserted and supported in the tank top risers for cesium removal. Temperature distributions and maximum temperatures across the column were calculated with a focus on process upset conditions. A two-dimensional computational modeling approach for the in-column ion-exchange domain was taken to include conservative, bounding estimates for key parameters such that the results would provide the maximum centerline temperatures achievable under the design configurations using a feed composition known to promote high cesium loading on CST. One salt processing scenario includes the transport of the loaded (and possibly ground) CST media to the treatment tank floor. Therefore, additional thermal modeling calculations were conducted using a three-dimensional approach to evaluate temperature distributions for the entire in-tank domain including distribution of the spent CST media either as a mound or a flat layer on the tank floor. These calculations included mixtures of CST with HLW sludge or loaded Monosodium Titanate (MST) media used for strontium/actinide sorption.

The current full-scale design for the CST column includes one central cooling pipe and four outer cooling tubes. Most calculations assumed that the fluid within the column was stagnant (i.e. no buoyancy-induced flow) for a conservative estimate. A primary objective of these calculations was to estimate temperature distributions across packed CST beds immersed in waste supernate or filled with dry air under various accident scenarios. Accident scenarios evaluated included loss of salt solution flow through the bed (a primary heat transfer mechanism), inadvertent column drainage, and loss of active cooling in the column.

The calculation results showed that for a wet CST column with active cooling through one central and four outer tubes and $35^{\circ} \mathrm{C}$ ambient external air, the peak temperature for the fully-loaded column is about $63^{\circ} \mathrm{C}$ under the loss of fluid flow accident, which is well below the supernate boiling point. The peak temperature for the naturally-cooled (no active, engineered cooling) wet column is $156{ }^{\circ} \mathrm{C}$ under fully-loaded conditions, exceeding the $130{ }^{\circ} \mathrm{C}$ boiling point. Under these conditions, supernate boiling would maintain the column temperature near $130{ }^{\circ} \mathrm{C}$ until all supernate was vaporized. Without active engineered cooling and assuming a dry column suspended in unventilated air at $35{ }^{\circ} \mathrm{C}$, the fully-loaded column is expected to rise to a maximum of about $258{ }^{\circ} \mathrm{C}$ due to the combined loss-of coolant and column drainage accidents.

The modeling results demonstrate that the baseline design using one central and four outer cooling tubes provides a highly efficient cooling mechanism for reducing the maximum column temperature. Results for the in-tank modeling calculations clearly indicate that when realistic heat transfer boundary conditions are imposed on the bottom surface of the tank wall, as much as 450 gallons of ground CST (a volume equivalent to two ion exchange processing cycles) in an ideal hemispherical shape (the most conservative geometry) can be placed in the tank without exceeding the $100{ }^{\circ} \mathrm{C}$ wall temperature limit. Furthermore, in the case of an evenly-distributed flat layer, the tank wall reaches the temperature limit after the ground CST material reaches a height of approximately 8 inches. 


\subsection{INTRODUCTION}

The Small Column Ion Exchange (SCIX) project is designed to accelerate closure of High Level Waste (HLW) tanks at the Savannah River Site (SRS). The SRS tanks store HLW in three forms: sludge, saltcake, and supernate. An in-tank ion exchange process is being designed to treat supernate and dissolved saltcake waste. Through this process, radioactive cesium from the salt solution is adsorbed into the ion exchange media (Crystalline Silicotitanate - CST) which is packed within a flow-through column. A packed column loaded with radioactive cesium generates significant heat from radiolytic decay. If engineering designs cannot handle this thermal load, hot spots may develop locally within the packed bed which could degrade the performance of the ion-exchange media. Performance degradation with regard to cesium removal has been observed between 50 and $80^{\circ} \mathrm{C}$ for CST [1]. In addition, the waste supernate solution will boil around $130^{\circ} \mathrm{C}$. If the columns boiled dry, the sorbent material could plug the column and lead to replacement of the entire column module.

The objective of the present work is to compute temperature distributions across a CSTpacked bed immersed in waste supernate and a dry, air-filled CST column under accident scenarios including loss of salt solution flow through the bed, complete loss of fluid inside the bed, and loss of coolant system flow. In addition, temperature distributions will be evaluated for a spent CST mound located on the tank floor and a layer of CST dispersed evenly across the tank floor. This is a potential fate of the spent CST after removal from the column. The spent CST will be ground prior to transfer to the tank in preparation for vitrification processing in the SRS Defense Waste Processing Facility (DWPF). Thermal evaluations were performed for the baseline design conditions of the ion-exchange column and the in-tank regions as shown in Figures 1 and 2 . The customer requested that calculations be conducted in such a manner as to ensure conservative and bounding results for the maximum temperatures achievable using the current baseline design. This effort expands on the work performed and documented previously [2-4].

Following the previous methodology [2-4], the current thermal modeling evaluations assumed the maximum bounding cesium loading considered possible based on current knowledge regarding CST media and assumed project controls with regard to feed qualification. Since this cesium loading was considerably higher than the nominal loading conditions in SRS waste, fractionally-decreased thermal loading cases were also evaluated. All other parameters were the same as those used previously unless otherwise indicated. The baseline design for the CST column was used for the initial calculations as shown in Figure 1. Detailed sensitivity analysis with respect to the initial baseline results were performed in order to identify key parameters that significantly impact the thermal performance. A temperature limit of $130{ }^{\circ} \mathrm{C}$ based on the salt solution boiling point was used as a measure for the evaluation of the in-column cases, although boiling cannot occur for the air-filled column case since no liquid is present.

For in-tank evaluations, the equipment configuration shown in Figure 2 involving a typical SRS Type-IIIA tank, Tank 41, as the baseline configuration. The location of the heat source region on the tank floor due to the accumulation of CST material was assumed to be just under the grinder. The shape of the CST heat source was assumed to be hemi-spherical for the most conservative evaluations. Selected alternative configurations involving other geometrical shapes for the CST mound were evaluated to 
ensure that the most conservative shape was used. In addition, evenly distributed layers of CST media were evaluated to simulate an ideally mixed tank. A tank wall temperature limit criterion of $100{ }^{\circ} \mathrm{C}$ was used for in-tank evaluations based on current SRS tank structural integrity temperature limits [5]. Sensitivity analysis for the in-tank region was performed for different amounts of CST and combinations of CST with loaded MST and sludge materials.

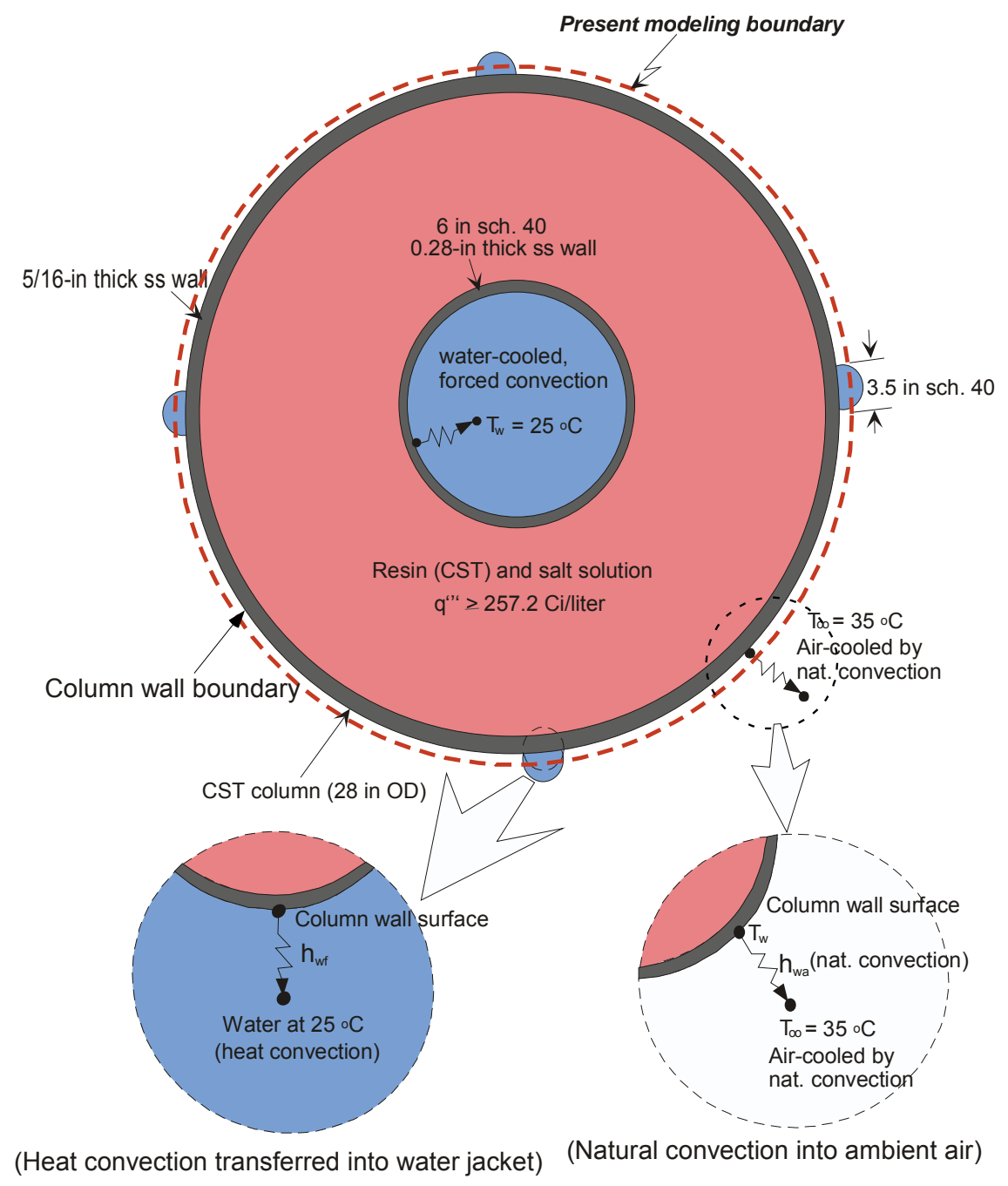

Figure 1. Baseline modeling domain for the ion-exchange column with CST media 


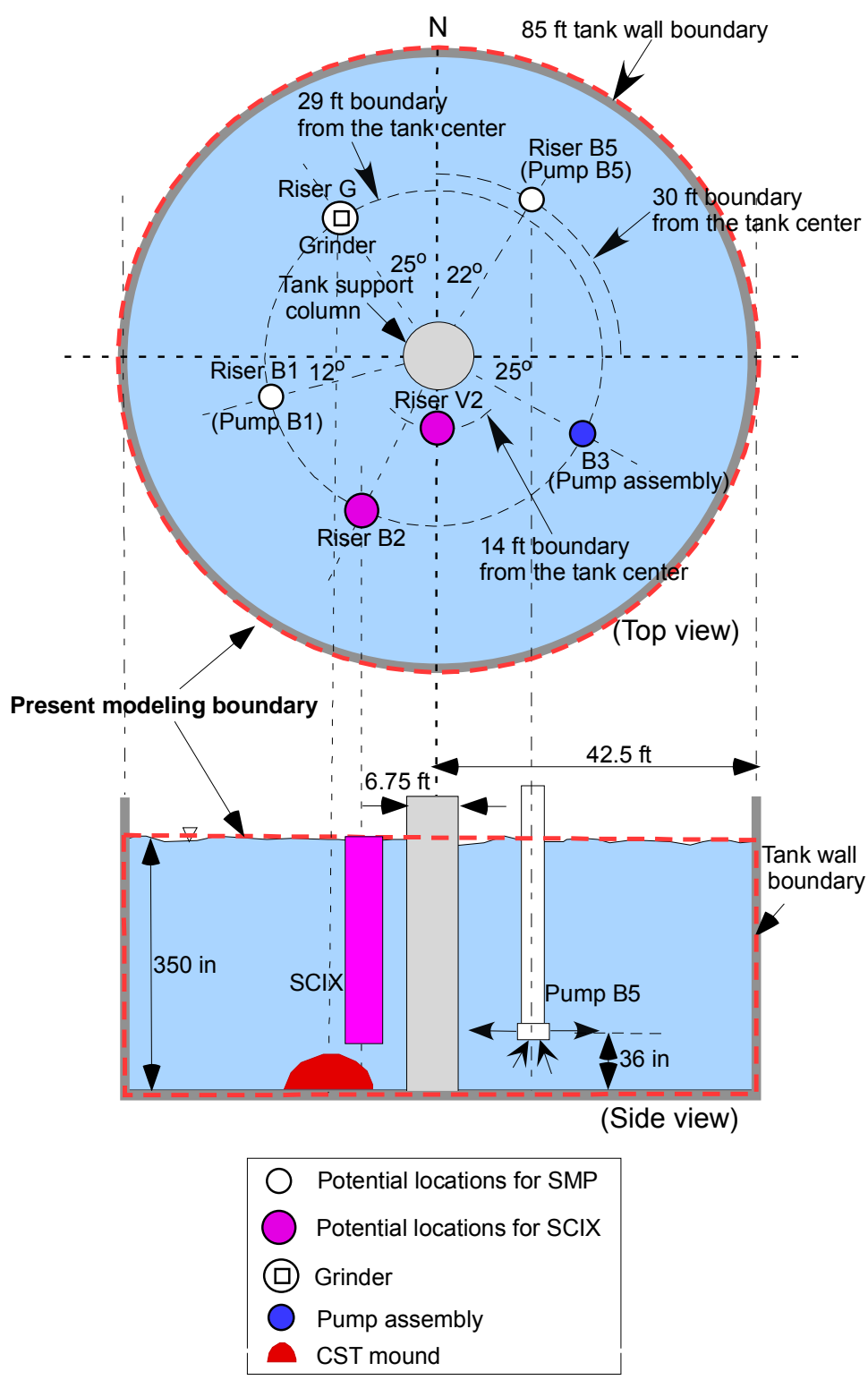

Figure 2. Initial baseline three-dimensional modeling boundary for in-tank calculations in the Tank 41 facility

\subsection{MODELING SCOPE AND APPROACH}

The SCIX modeling and analysis scope included two main domain areas. One involves the in-column heat transfer analysis for an ion exchange column containing CST and either salt solution or air. The other is an in-tank domain which includes the entire waste tank with accumulated spent CST materials on the floor. This work was conducted as prescribed in the "Task Plan For Thermal Modeling of lon Exchange Columns with Spherical RF Resin" [6]. 
The SCIX in-tank cesium-removal system contains two ion-exchange column modules and one IX media grinder inside an 85-ft diameter SRS Type-IIIA tank. The column module is designed for cesium removal from an SRS High-Level Waste (HLW) salt solution containing numerous radioactive species. The columns are packed with Crystalline Silicotitanate ion exchange media. The baseline design includes a 15 foot tall column with an annular design which contains 450 gallons of CST media. The supernate is an alkaline, concentrated sodium salt solution (nominally $6 \mathrm{M} \mathrm{Na}^{+}$). Through this process, radioactive cesium from the salt solution is adsorbed onto the ion exchange media, which is packed within the flow-through column. The packed ion exchange column loaded with radioactive cesium $\left(\sim 5 \times 10^{5} \mathrm{Ci}\right)$ generates significant heat from radiolytic decay. Under normal operating conditions, process fluid flow through the column can provide adequate heat removal from the system through a coupled conduction and convection heat transfer mechanism. However, in the case of loss of fluid flow or inadvertent solution leakage from the column, there are safety concerns about the thermal response rate of the fully-loaded column and the effectiveness of the column cooling system. If engineering designs cannot handle this thermal load, hot spots may develop locally within the bed which could degrade the performance of the ion-exchange media. The waste supernate solution will also boil around $130^{\circ} \mathrm{C}$. If the columns boiled dry, the resulting solid sodium salts could foul and plug the column. The baseline design for the column module shown in Figure 1 is used as the calculation domain. Detailed sensitivity analysis with respect to the baseline results were performed in order to identify the key parameters that significantly impacted the thermal performance inside the column. The baseline modeling conditions used for the incolumn analysis are provided in Table 1.

For computational modeling purposes, a conservative approach is taken by assuming that the primary cooling mechanisms inside and outside of the column are conduction and natural convection, respectively, and axial heat removal effects from the column are negligible compared to radial heat transfer. A two-dimensional transient heat conduction model was developed to assess the thermal performance of the CST column with loss of flow using the prototypic geometry. The model was created using the body-fitted coordinate system and structured multi-block grids in the Computational Fluid Dynamics (CFD) preprocessing environment. Heat transfer analysis of the CST column is performed for a given boundary condition by using a computational heat transfer approach on a Cartesian $x-y$ grid under the commercial CFD code, FLUENT environment. The corresponding computational domain presented in Figure 3 indicates that about 8,000 mesh nodes are established for the in-column thermal analysis.

The model considers two basic process scenarios with no fluid flow. One case involves a packed CST bed filled with salt solution, while the other involves a packed CST bed filled with air and no salt solution. The dry column could potentially result from processing accidents such as inadvertent fluid drainage resulting from incorrect valve operations or column overheating and solution boiling. Spherical CST particles are assumed to be homogeneously packed inside a stainless steel cylinder that is 28 inches in diameter with a 0.5 inch thick wall. Detailed material and thermal properties for the wet and dry CST columns are summarized in Table 2. The CST packed bed porosity was estimated to be about $43.2 \%$ based on ORNL measurements [7]. The void volume fraction of the packed bed has a substantial impact on estimations of the thermal conductivity of a composite mixture. In the ORNL work, the bulk density of the CST column filled with air was estimated to be about $1,168 \mathrm{~kg} / \mathrm{m}^{3}$ assuming that the density of CST solid is 2,056 $\mathrm{kg} / \mathrm{m}^{3}$. 
Modeling calculations for the in-column analysis were based on a two-dimensional approach involving the following assumptions (unless otherwise indicated) in order to ensure conservative results for the maximum temperatures.

- The column is filled with a fixed, packed bed of CST particles with homogeneous packing.

- The CST bed is immersed in salt solution or air with no active or convective fluid flow through the bed. One analysis case involved nominal fluid flow through the bed.

- The CST particle and salt solution (or air for the dry bed case) are in local thermal equilibrium so that an average effective thermal conductivity can be assumed for the packed bed.

- The column is suspended in unventilated dry air at $35^{\circ} \mathrm{C}$ rather than salt solution within the High Level Waste tank head space.

- The initial heat source term used of $257 \mathrm{Ci} / \mathrm{L}$ of packed bed is $115 \%$ of the maximum cesium loading of $223 \mathrm{Ci} / \mathrm{L}$ predicted for the various SRS waste compositions previously considered for SCIX processing [8]. The heat source was calculated assuming secular equilibrium involving ${ }^{137} \mathrm{Cs}$ and ${ }^{137 \mathrm{~m}} \mathrm{Ba}$ decay. The heat source is assumed to be uniformly distributed throughout the entire packed column as would be expected for cesium-saturated media. This Curie loading corresponds to $1.273 \mathrm{~kW} /$ liter.

- Outside the column there is no forced convective airflow, so natural convection is the primary heat transfer mechanism from the exterior column wall. Radiative cooling contributions at the outer wall surfaces of the column are also considered.

- A typical natural convective heat transfer coefficient $\left(h_{w}\right)$ of $1.5 \mathrm{~W} / \mathrm{m}^{2} \mathrm{~K}$ was used as an external wall boundary condition based on previous analysis [3].

When the column becomes dry as a result of accidental drainage or solution boiling, the following additional assumptions were used.

- The CST material is completely dry throughout the bed and remains homogeneously packed.

- The air-packed column volume remains fixed relative to the initial packed configuration.

- Chemical reactions of the dried CST media material that could lead to changes in the thermal or physical properties of the packed bed are neglected.

- Air convection inside the column is conservatively neglected and only conductive heat transfer is considered.

- Radiative cooling contributions to the heat transfer at the inner column wall surfaces are neglected.

Using the modeling boundary shown in Figure 1 and the computational mesh shown in Figure 3 , the in-column modeling calculations were performed for a range of conditions 
to estimate maximum temperatures in a conservative way. The in-column modeling conditions used for the present analysis are summarized in Table 3.

For the baseline in-column analysis, the column was assumed to be cooled by natural convection. The heat transfer coefficient at the outside wall of the column $\left(h_{w}\right)$ was obtained by using an empirical correlation available in the literature. In this situation, the natural convection flow regime for the air-cooled design should be estimated based on the non-dimensional Grashof number $\left(\mathrm{Gr}_{\mathrm{L}}\right)$, which is the parameter describing the ratio of buoyancy to viscous forces for a vertically-oriented cylinder with height L. The Grashof number performs much the same function for natural convection flow as the Reynolds $(\mathrm{Re})$ number does for forced convection. Under normal conditions one may expect that the laminar-to-turbulent transition will take place between $G r_{L} \approx 10^{9}$ and $10^{10}$ [9].

A typical natural convective heat transfer coefficient $\left(h_{w}\right)$ of $1.5 \mathrm{~W} / \mathrm{m}^{2} \mathrm{~K}$ was used as an external wall boundary condition from previous work $[2,10,11]$. The value of the heat transfer coefficient can be justified on the following basis.

For a conservative calculation, a low temperature gradient at the wall boundary layer was used to estimate the natural convection capability for the present geometrical configurations. The heat transfer coefficient $\left(h_{w}\right)$ for natural convective cooling under a turbulent flow regime $\left(\mathrm{Ra}_{f}=\mathrm{Gr}_{L} \mathrm{Pr}_{f}>10^{9}\right)$ is given in terms of non-dimensional numbers empirically.

$N u_{L}=\frac{h_{w} L}{k_{w}}=C\left(G r_{L} \operatorname{Pr}_{f}\right)^{m} \quad$ for $\operatorname{Gr}_{L} \operatorname{Pr}_{f}<10^{12}$

where $\mathrm{C}$ and $\mathrm{m}$ are the coefficients determined from literature data and $L$ is the characteristic length of the CST column.

For the present geometrical configuration, $\mathrm{C}=0.10$ and $\mathrm{m}=0.333$ are given by Warner and Arpaci using the experimental data [12]. From eq. (1), the heat transfer coefficient $\left(h_{w}\right)$ is about $1.5 \mathrm{~W} / \mathrm{m}^{2} \mathrm{~K}$ corresponding to $N u_{L} \approx 254$ conservatively under the present conditions. Figure 4 shows the quantified results for the literature correlation based on laminar natural convection, which was developed by Warner and Arpaci. The figure shows the conservatism imbedded in the present modeling conditions involving natural convection through the exterior wall surface of the CST column containing the decay heat source.

Heat transfer coefficients $\left(h_{\mathrm{wf}}\right)$ for forced convective heat transfer mechanisms through the column wall attached to the water jackets and through the inner surface of the coolant pipe at the column center were estimated by Dittus-Boelter's correlation [13]. That is,

$N u_{d}=\frac{h_{w f} d_{h}}{k_{w f}}=0.023\left(R e_{d}\right)^{0.8}\left(P r_{w f}\right)^{a}$ for $R e_{d}>2000$

Equation (2) is applicable to turbulent flow when the Reynolds number is larger than 2,000 in terms of the hydraulic diameter $d_{h}$, and the parameter $a$ in eq. (2) is 0.4 when the fluid is heated as modeled in the present work. The Reynolds number for the present study is about 7,000 when $6.25 \mathrm{gpm}$ flows through the 3.5 -in half-moon coolant tubes, which corresponds to $0.25 \mathrm{~m} / \mathrm{sec}$ flow velocity. In the present work, some 
modeling cases include active engineered cooling systems with a forced convection mechanism as shown in Table 3. Forced convection heat transfer coefficients at the water jackets $\left(h_{w f}\right)$ attached to the exterior of the column wall and at the inner surface of 6 -in water pipe were estimated by eq. (2). From the baseline modeling conditions, the wall heat transfer coefficient governed by a forced convection mechanism was estimated as $h_{w f}=238\left(\mathrm{~W} / \mathrm{m}^{2} \mathrm{~K}\right)$ for the wall surface of the 6 -in central coolant pipe and $h_{w f}=620$ $\left(\mathrm{W} / \mathrm{m}^{2} \mathrm{~K}\right)$ for the wall of 3.5-in water jacket. Figure 5 shows quantified results for the present modeling conditions in terms of Reynolds number.

The main design parameters involved for the heat transfer in a fixed bed SCIX column are as follows:

- Ambient air temperature around the column system

- Heat load of the CST column

- $\quad$ Bed thermal properties

- External and internal heat removal capability of the column such as coolant pipe size and flow conditions

Table 3 presents the modeling conditions for the baseline design of the 28-in cesiumsaturated CST column. Table 4 shows a range of total heat loads generated by the SCIX column. These heat loads were used as the volumetric heat source term q"' for the modeling calculations.

The solution methodology has been established to calculate steady-state and transient temperature responses of the column system to the heat load q"'. The transient calculations were continued until maximum temperatures for the components were reached. In this work, two temperature limits were used for the operation and safety criteria in the thermal evaluation of the SCIX system. One was an operating temperature limit to prevent overheating of tank supernate, which is the $55^{\circ} \mathrm{C}$ liquid temperature limit for the entire liquid domain of Tank 41 containing the CST column modules and spent CST mound. The other is used as a safety limit, which is the $100^{\circ} \mathrm{C}$ temperature limit for the corrosion control of the tank wall material [5].

Complete setup of the modeling calculations requires the input parameters such as thermal and material properties of the components, heat source term, and initial boundary conditions along with the established modeling domain. For the heat transfer analysis of the CST column, the governing equations are applied to the two-dimensional computation domain as shown in Figure 1, assuming that the axial heat transfer of the column is negligible. For conservative heat transfer calculations, the heat source was estimated for a fully-loaded and uniformly-distributed bed packed with CST solid material. The initial calculations used $257 \mathrm{Ci} /$ liter for CST, corresponding to 1.273 watts/liter, as volumetric heat source q"' as shown in Table 5 . The total power generated by the CST column was obtained by multiplying the volumetric source by the total net column volume for each of the three different heights $(10,15,25 \mathrm{ft})$. In addition, this region was included as a conduction zone and was assumed to have constant thermal conductivity instead of considering temperature-dependency for the steady-state energy equation. However, the transient model considered temperature-dependent thermal properties to predict transient thermal responses of the fixed bed region in the case of loss of solution flow. 
Two-dimensional steady-state and transient conduction models were performed to estimate the maximum column temperature of the CST fixed bed and to determine the transient thermal response of the bed region in case of loss of process fluid. For computational efficiency, an effective thermal conductivity for the composite column region was used. The effective thermal conductivity of the CST bed region was estimated by a literature correlation [7]. That is, the effective thermal conductivity of the bed $\left(k_{b, \text { eff }}\right)$ was developed as a function of the bed porosity, . $\varepsilon$, in $S I$ units $(\mathrm{W} / \mathrm{mK})$ using the literature experimental data.

$k_{b, \text { eff }}=k_{f}\left(\frac{k_{\text {peff }}}{k_{f}}\right)^{A+B \log \left(\frac{k_{\text {peff }}}{k_{f}}\right)}$

where

$$
\begin{aligned}
& A=0.280-0.757 \log \varepsilon \text { and } B=-0.057 . \\
& k_{\text {peff }}=\varepsilon_{p} k_{f}+\left(1-\varepsilon_{p}\right) k_{p}
\end{aligned}
$$

In eq. (3), $k_{\text {peff }}$ is the effective thermal conductivity of a CST particle considering particle porosity, $\varepsilon_{p} . k_{f}$ in eq. (3) is the thermal conductivity of the stagnant fluid trapped inside the porous CST particle. Coefficient $A$ is a function of the bed porosity, $\varepsilon$. The thermal conductivity of the CST particle $\left(k_{p}\right)$ is assumed to be constant for computational efficiency.

Effective material properties of the CST column are computed in terms of the bed porosity of the packed column, $\varepsilon$. Effective density, $\rho_{b, \text { eff, }}$ and specific heat, $C p_{b \text {,eff, of the }}$ bed column are based on a homogeneous assumption. That is,

$\rho_{b, \mathrm{eff}}=\varepsilon \rho_{f}+(1-\varepsilon) \rho_{\text {peff }}$

Effective particle density, $\rho_{\text {peff, }}$ is given by the particle porosity, $\varepsilon_{p}$.

$\rho_{\text {peff }}=\varepsilon_{p} \rho_{f}+\left(1-\varepsilon_{p}\right) \rho_{p}$

$C p_{b, \text { eff }}=\varepsilon C p_{f}+(1-\varepsilon) C p_{\text {peff }}$

Effective particle specific heat, $C p_{\text {peff, }}$ is given by the particle porosity, $\varepsilon_{p}$.

$C p_{\text {peff }}=\varepsilon_{p} C p_{f}+\left(1-\varepsilon_{p}\right) C p_{p}$

In eqs. (6) and (7), subscripts $f$ and $p$ refer to the fluid and particle materials within the packed bed, respectively. Computational time can be reduced by modeling a singlematerial region with the effective thermal conductivity instead of modeling a multimaterial region composed of two different materials. This leads to a significant reduction in effort with little impact on accuracy.

Based on the computational domain and meshes as shown in Figures 3 and 10, the thermal performance calculations were performed by employing two temperature limits. Safety criteria limits for the column solution and tank wall temperatures are assumed to be $130{ }^{\circ} \mathrm{C}$ and $100{ }^{\circ} \mathrm{C}$, respectively. These criteria were selected to prevent waste supernate boiling and to avoid structural damage to the tanks. A temperature limit of 55 ${ }^{\circ} \mathrm{C}$ for the in-tank solution outside the CST column is also assumed for operational control. Using these temperature criteria, various thermal calculations for the in-column 
module and the in-tank domain were made to quantify key design and operating parameters and evaluate performance with and without engineered cooling systems. For the case of the air-filled column, a series of transient modeling calculations were conducted to determine the maximum bed temperature as a function of time.

This analysis is conservative by nature and gives bounding temperature data. Only conductive heat transfer was considered and it was assumed that the thermal conductivity of the CST material was constant with temperature. Additional transient calculations were conducted under the wet and dry column conditions using a cesium loading of $300 \mathrm{Ci} /$ liter. The modeling results provide quantitative information associated with process heat control and management of the SCIX design.

The two-dimensional geometry was created using the multi-block preprocessor of the Fluent ${ }^{\mathrm{TM}}$ code [14] under the body-fitted coordinate system, which allows for the treatment of non-orthogonal geometries. The present model consists of 2 element blocks and 2 different material zones on the $x-y$ computational plane. Non-uniform twodimensional structured meshes of the computational domain were used to capture the smooth temperature gradient across the boundary zone of the two different material regions as shown in Figure 3. The governing equations defined by the computational grid were solved by an iterative solution method. The detailed solution methodology was described in the previous work [2].

The overall energy balance should be checked to demonstrate the adequacy of the grid fineness used. This was done by using eq. (10).

$$
R=-\int_{A_{W}} q_{w}^{\prime \prime} d A+q^{\prime \prime \prime} V_{b}
$$

The volumetric heat source term, q'", in eq. (10) is given by the code input. For all the cases considered here, the absolute value of the energy residual $(R)$ was maintained at a value less than 0.5 watts. For instance, the residual results for the wet column model with active central and external cooling systems are shown as function of the grid number in Figure 6 . For the present analysis, an optimum grid of about 8,100 cells for the 28-in column was established from the grid sensitivity analysis under the Linux high performance platform. Nonuniform two-dimensional meshes used for the computational analysis of the 28-in column are shown in Figure 3. 
Table 1. Baseline modeling conditions used for the heat transfer analysis of the ion exchange column.

\begin{tabular}{|c|c|}
\hline Models & Conditions for the baseline model \\
\hline Column heat load & 257.22 Ci/liter (1273.24 W/m³) [8] \\
\hline CST material porosity & $24.0 \%[7]$ \\
\hline Column hydraulic conditions & no flow, or $5 \mathrm{gpm}$ flow* \\
\hline Column media & wet or dry column* \\
\hline Granular bed conditions & fixed bed \\
\hline Initial temperature & $35^{\circ} \mathrm{C}$ for the entire computational domain \\
\hline Ambient temperature & $35^{\circ} \mathrm{C}\left(55^{\circ} \mathrm{C}\right)^{*}$ \\
\hline $\begin{array}{l}\text { Heat transfer coefficient at } \\
\text { wall, } h_{w}\left(\mathrm{~W} / \mathrm{m}^{2} \mathrm{sec}\right)\end{array}$ & $\begin{array}{l}238 \text { (for } 6 \text {-in water pipe wall), and } 620 \text { (for the column } \\
\text { wall surface attached to the water jacket), } 1.5 \mathrm{~W} / \mathrm{m}^{2} \mathrm{sec} \\
\text { (typical natural convection) }[10]^{\star *}\end{array}$ \\
\hline $\begin{array}{l}\text { Coolant water flowrate in } \\
\text { cooling jackets }\end{array}$ & $\begin{array}{c}6.25 \mathrm{gpm} \text { each side jacket, } 12.5 \text { for annular central } \\
\text { coolant pipe }\end{array}$ \\
\hline Coolant water temperature & $\begin{array}{c}\text { no forced circulation or } 25^{\circ} \mathrm{C}\left(35^{\circ} \mathrm{C}\right)^{*} \text { fixed by forced } \\
\text { circulation }\end{array}$ \\
\hline Bed porosity & $43.2 \%[7,10,11]$ \\
\hline
\end{tabular}

${ }^{\#}$ All Curies assumed converted to heat load wattage

${ }^{*}$ Conditions to be evaluated by sensitivity analysis

${ }^{* *}$ Heat transfer coefficient at the exterior wall of the CST column 
Table 2. Material and thermal properties for heat transfer calculations of the CST, column, tank and soil

\begin{tabular}{|c|c|c|c|}
\hline Material & $\begin{array}{c}\text { Thermal conductivity } \\
(\mathrm{W} / \mathrm{mK})\end{array}$ & $\begin{array}{c}\text { Density } \\
(\mathrm{kg} / \mathrm{m} 3)\end{array}$ & $\begin{array}{c}\text { Specific heat } \\
(\mathrm{J} / \mathrm{kgK})\end{array}$ \\
\hline CST [7] & 0.1617 & $2056.3^{* *}$ & 1052.3 \\
\hline Salt Solution [8] & 0.68 & 1232.0 & 3630.0 \\
\hline $\begin{array}{c}\text { CST-Salt Solution } \\
\text { Solution }\end{array}$ & $0.4125^{\#}$ & $\begin{array}{c}1587.8^{\#} \\
\text { (from eqn. } 8)\end{array}$ & $\begin{array}{c}2517.3^{\#} \\
\text { (from eqn. 9) }\end{array}$ \\
\hline $\begin{array}{c}\text { Ground CST-Salt } \\
\text { CST-Air }\end{array}$ & $0.3386^{\#}$ & $\begin{array}{c}1723.2^{\#} \\
\text { (from eqn. }\end{array}$ & $\begin{array}{c}2094.1^{\#} \\
\text { (from eqn. 9) }\end{array}$ \\
\hline Stainless steel [20] & $-1.0922 \times 10^{-2}+4.0960 \times 10^{-4} \mathrm{~T}^{*}$ & $1168.0^{* * *}$ & $1031.9^{* * *}$ \\
\hline Concrete & 17.30 & 7800.0 & 486.0 \\
\hline Ceramic & 1.5 & 2400 & 750 \\
\hline soil & 18.0 & 3690 & 880 \\
\hline
\end{tabular}

\# based on non-linear empirical correlation of Krupiczka at $25^{\circ} \mathrm{C}$ [15] considering particle porosities $\left(\varepsilon_{\mathrm{CST} \text {, particle }}=24 \%, \varepsilon_{\mathrm{RF} \text {, particle }}=65.79 \%\right.$ ) and the volume fractions of air or fluid in the packed beds $(0.432$ for CST bed), giving total bed porosities of 0.57 for CST (total porosity evaluated considering bead and bed porosity.). In case of ground CST for the in-tank modeling analysis, porosity is assumed to be reduced by $50 \%$ from the void filling with smaller ones.

${ }^{*} \mathrm{~T}$ is absolute temperature in $\mathrm{K}[16]$

${ }^{* *}$ based on material density (not bulk density)

*** based on the condition that volume fraction of fluid or air in packed bed is 0.432 at $25^{\circ} \mathrm{C}$ temperature

\#HLW-SDT-2000-00456, Rev. 0, October 30, 2000. 
Table 3. Modeling cases used for the in-column analysis

\begin{tabular}{|c|c|c|c|}
\hline \multirow{2}{*}{$\begin{array}{l}\text { CST loading } \\
\text { (Curie/liter) }\end{array}$} & \multirow{2}{*}{$\begin{array}{l}\text { Column Hydraulic } \\
\text { conditions }\end{array}$} & \multicolumn{2}{|c|}{ Engineered cooling system } \\
\hline & & $\begin{array}{c}\text { Central cooling } \\
\text { system }\end{array}$ & $\begin{array}{c}\text { External cooling } \\
\text { system }\end{array}$ \\
\hline \multirow{5}{*}{$\begin{array}{c}257 \\
\text { (Baseline loading) }\end{array}$} & $5 \mathrm{gpm}$ flow & Active & Active \\
\hline & Stagnant (Wet) & Active & Active \\
\hline & Stagnant (Wet) & Inactive & Inactive \\
\hline & Stagnant (Dry) & Active & Active \\
\hline & Stagnant (Dry) & Inactive & Inactive \\
\hline \multirow{4}{*}{300} & Stagnant (Wet) & Active & Active \\
\hline & Stagnant (Wet) & Inactive & Inactive \\
\hline & Stagnant (Dry) & Active & Active \\
\hline & Stagnant (Dry) & Inactive & Inactive \\
\hline
\end{tabular}

Table 4. Heat source terms for the baseline column shown in Fig. 1.

\begin{tabular}{|c|c|c|c|}
\hline \multirow{2}{*}{$\begin{array}{c}\text { Column height } \\
(\mathrm{ft})\end{array}$} & $\begin{array}{c}\text { Total column } \\
\text { volume } \\
\text { (liters) }\end{array}$ & $\begin{array}{c}\text { Volumetric heat load, } \\
\text { q"” } \\
\text { Ci/liter [watts/liter] }\end{array}$ & $\begin{array}{c}\text { Total heat sources } \\
\text { generated by column } \\
\text { loading (watts) }\end{array}$ \\
\hline \multirow{2}{*}{10} & 1154.7 & $257[1.273]^{* *}$ & 1470 \\
\cline { 3 - 4 } & \multirow{2}{*}{1732.0} & $300[1.485]$ & 1715 \\
\cline { 3 - 4 } & \multirow{2}{*}{2886.6} & $300[1.485]$ & 2205 \\
\cline { 3 - 4 } & & $257[1.273]^{* *}$ & 2572 \\
\hline \multirow{2}{*}{25} & $300[1.485]$ & 3675 \\
\hline
\end{tabular}

${ }^{*}$ Conversion factor for Cs-137 decay heat is 0.00495 watts/Ci.

${ }^{* *}$ Baseline loading. 


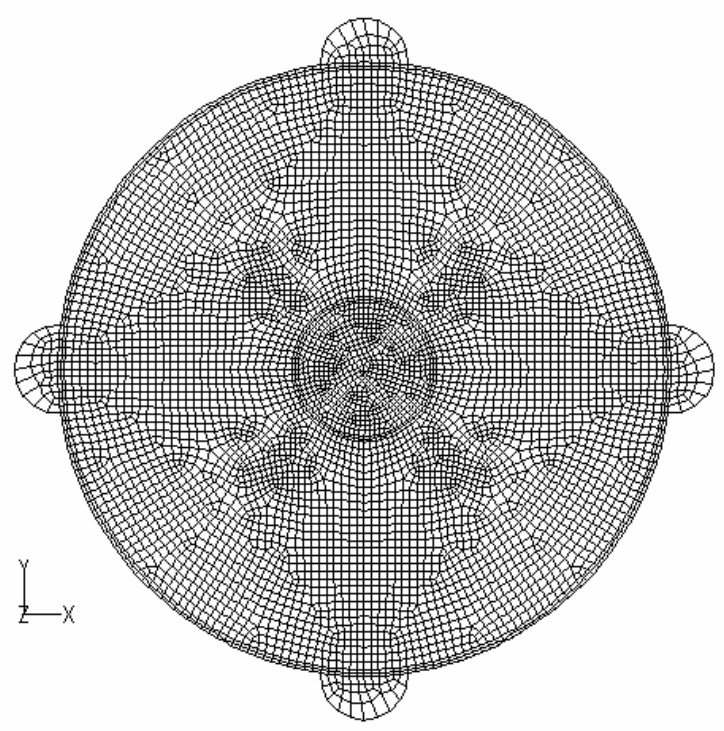

Figure 3. Two-dimensional computational mesh used for the in-column modeling calculations (about 10,000 mesh nodes)

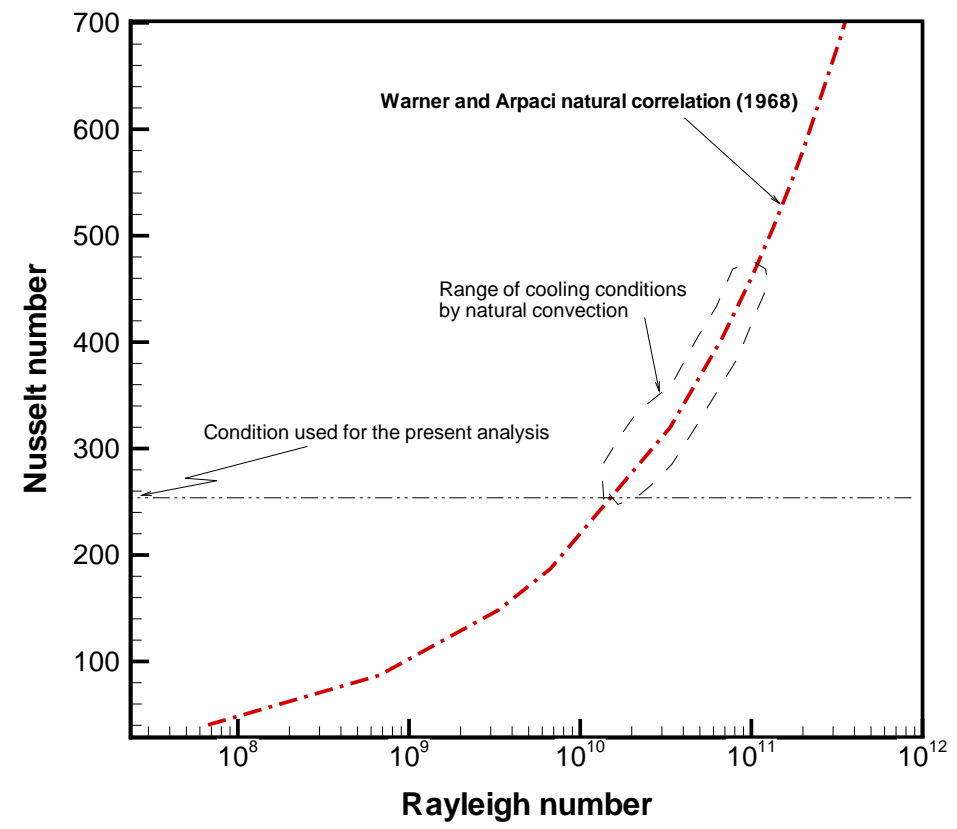

Figure 4. Natural convection heat transfer correlation available in the literature showing the conservatism imbedded in the present heat transfer analysis 


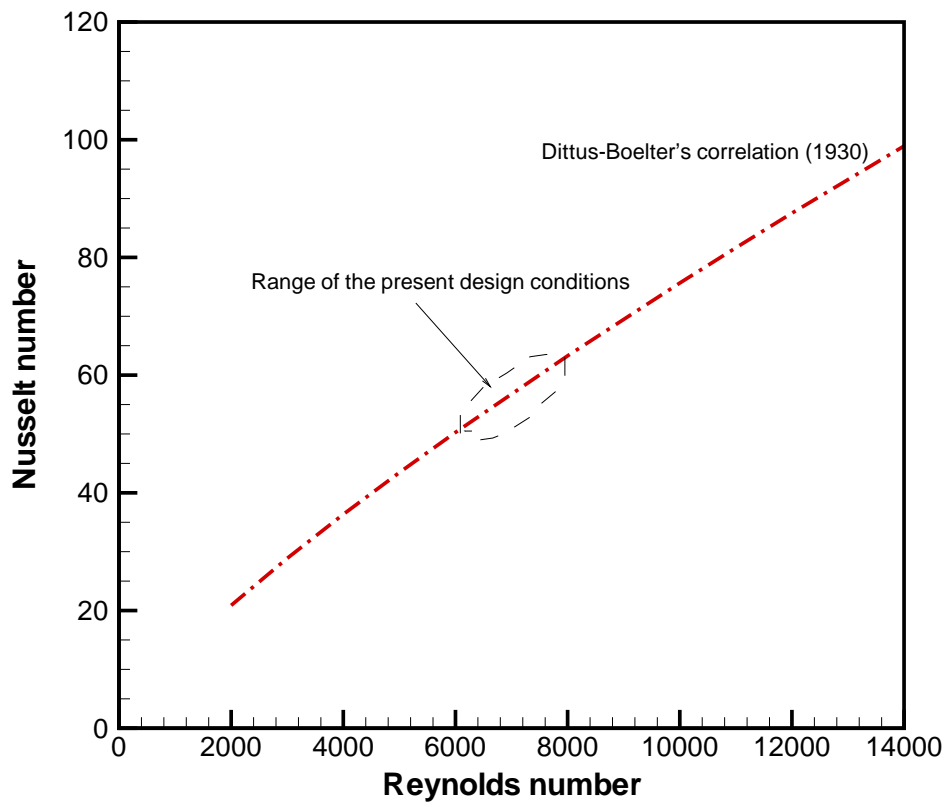

Figure 5. Forced convection correlation available in the literature demonstrating the range of convective heat transfer through the column water cooling system

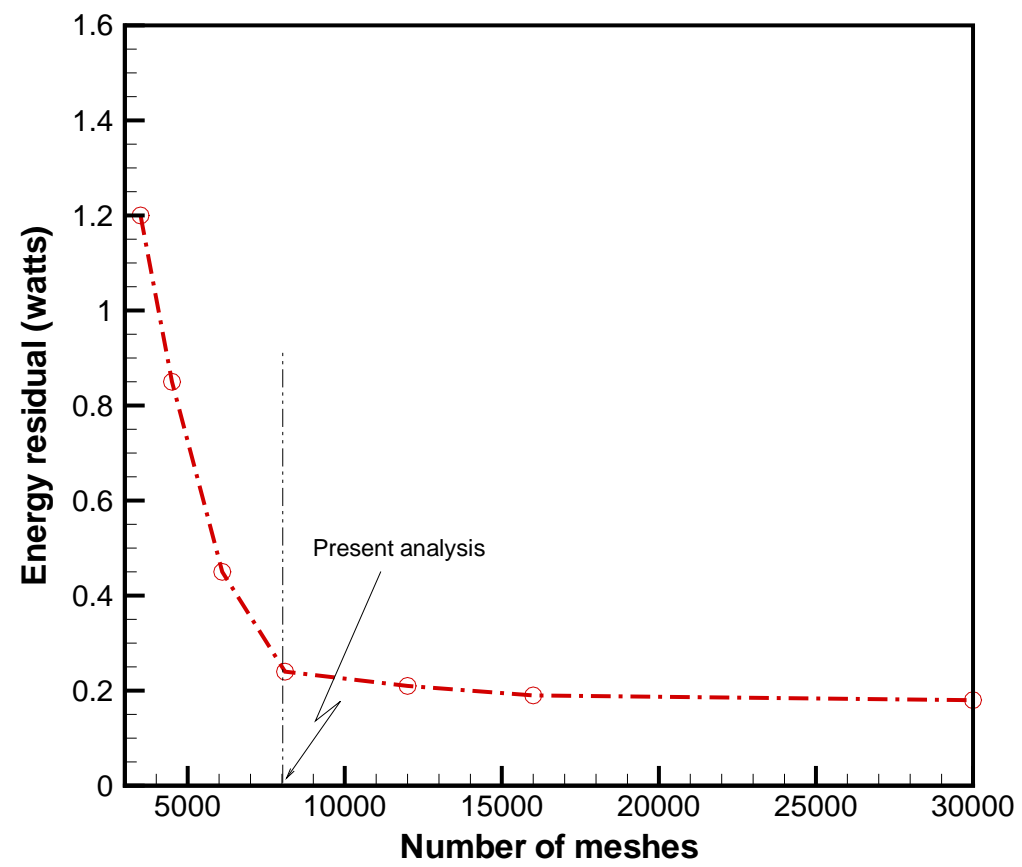

Figure 6. Sensitivity results associated with numerical energy residual showing that approximately 8,100 meshes are sufficient for the present analysis 
When the spent CST material is dropped to the treatment tank floor for interim storage, there are safety concerns about reaching the maximum allowable temperature at the tank wall region under the CST mound. The tank wall temperature cannot be higher than $100^{\circ} \mathrm{C}$. Figure 2 shows the equipment configuration inside the SRS tank, which serves as the baseline configuration for the in-tank thermal analysis. Figures 7 and 8 show the modeling geometries for the hemispherical mound and the flat CST layer, respectively. Note that although air cooling channels are shown in these drawings it not believed that significant cooling air flow passes beneath the tank since no direct forced air flow is applied to these channels. 23 cooling coils equivalent in surface area to the total heat transfer area of 548 cooling coils in Tank 41 are used as shown in Figure 9. Material and thermal properties assumed for the in-tank calculations are provided in Table 2. Three-dimensional in-tank heat transfer models were developed to estimate the maximum temperatures for the liquid and for hot spots on the tank floor under conservative and bounding assumptions. The initial thermal calculations for the entire in-tank domain considered two cases as shown in Table 5 involving 6,000 gallons of unground spent CST present on the tank floor as a hemispherical mound or as flat layer. A volume of 6,000 gallons was selected by the customer based on the maximum amount of spent CST that might accumulate on the tank floor during processing. The location of the CST mound for Case 1 is just under the grinder region while the flat layer for Case 2 covers the entire bottom tank surface.

Figure 11 presents three-dimensional modeling geometries for two geometrical shapes of the in-tank CST accumulations under the CFD computational platform. When the cooling capability is assumed to be uniform over the entire surface area of the 6000gallon CST mound with its adiabatic bottom surface, heat flow per unit surface area for the flat layer is about 17 times less than that of the hemispherical mound as compared in Table 5. As shown in Figure 10, about 2,000,000 computational nodes are established for the in-tank calculations.

Table 5. Comparison of the two initial in-tank analysis cases with adiabatic floor conditions

\begin{tabular}{|c|c|c|c|c|c|}
\hline Cases & $\begin{array}{c}\text { CST } \\
\text { volume } \\
\text { (gallons) }\end{array}$ & $\begin{array}{c}\text { Total } \\
\text { thermal } \\
\text { load }(\mathrm{kW})\end{array}$ & $\begin{array}{c}\text { Mound shape } \\
\text { and location } \\
\text { (See Fig. 8 }\end{array}$ & $\begin{array}{c}\text { Mound } \\
\text { height } \\
\text { (inches) }\end{array}$ & $\begin{array}{c}\text { Ratio* of cooling } \\
\text { surface area to } \\
\text { volume }(1 / \mathrm{m})\end{array}$ \\
\hline Case 1 & 6000 & 28.9 & $\begin{array}{c}\text { Hemisphere } \\
\text { under Riser G }\end{array}$ & $\begin{array}{c}87 \text { in } \\
\text { radius }\end{array}$ & 1.36 \\
\hline Case 2 & 6000 & 28.9 & $\begin{array}{c}\text { Evenly flat layer } \\
\text { on tank floor }\end{array}$ & $\begin{array}{c}1.7 \text { in } \\
\text { height }\end{array}$ & 23.22 \\
\hline
\end{tabular}

${ }^{*}$ based on adiabatic bottom surface of CST mound

Major modeling assumptions for the in-tank calculations are as follows.

- The spent CST media was unground for initial analysis cases while later evaluations considered ground material. 
- The waste tank was considered full (330 inches) of stagnant $6 \mathrm{M} \mathrm{Na}^{+}$supernate with the mixing pumps turned off so that the primary cooling mechanism was natural convection due to buoyancy effects in the tank fluid with the primary heat transfer to the tank cooling system. One modeling case considered a lower liquid level.

- The tank side wall boundary was cooled by ambient air via a free convectionconduction mechanism coupled with thermal radiation.

- The tank bottom wall boundary was assumed to be adiabatic for initial estimates such that heat transfer through the tank bottom was not allowed. Later evaluations included heat dissipation across the tank bottom to the 150-ft deep soil region [10].

- Water was maintained as a single phase for simplification and conservatism even if local water temperatures near the CST mound exceeded the supernate boiling point of $130^{\circ} \mathrm{C}$.

- Initial temperatures for water, CST, and ambient air were $35^{\circ} \mathrm{C}$.

- The tank wall thickness was assumed to be a constant value of 0.5 inches.

- 23 equivalent cooling coils corresponding to the total cooling surface area of the entire submerged cooling system (548 tubes, 2-in. diameter) in Tank 41 were evenly distributed across the tank fluid region.

- The cooling coil wall surface temperature was kept constant at $35^{\circ} \mathrm{C}$.

- The baseline CST heat loading was assumed to be $257 \mathrm{Ci} /$ liter of packed bed.

For calculations involving HLW sludge mixed with ground CST, the sludge thermal loading was conservatively estimated using a heat loading calculated for a $13 \mathrm{wt}$. \% sludge/supernate slurry containing 5 year old sludge and 15 year old supernate [21]. Five year old sludge would be expected to have a much higher heat loading than the aged sludge that is currently present in the SRS waste tanks. A sludge heat load of $0.421 \mathrm{~W} / \mathrm{gal}$ was calculated. Assuming that a $13 \mathrm{wt}$. \% slurry contains $30 \%$ sludge by volume, a sludge heat loading of $334 \mathrm{~W} / \mathrm{m}^{3}$ was calculated and used for the thermal modeling calculations.

For calculations involving spent MST mixed with ground CST, the MST thermal loading was estimated based on assumed loadings of Sr-90 and Pu-238. The strontium and plutonium contributions to the MST heat source were calculated based on the following assumptions:

- a phase ratio of $0.4 \mathrm{~g} \mathrm{MST/L}$ supernate

- $\quad 6.85 \mathrm{E}-5 \mathrm{M}$ total $\mathrm{Sr}$

- $100 \%$ strontium sorption onto MST

- $\quad 0.21$ wt. \% Pu loading on MST 
- supernate containing $10 \% \mathrm{Sr}-90$ and $50 \%$ Pu-238

- secular equilibrium between $\mathrm{Sr}-90$ and $\mathrm{Y}-90$ resulting in an effective heat source of $0.932 \mathrm{~W} / \mathrm{g} \mathrm{Sr}-90$

Based on these assumptions, individual elemental contributions to the heat source were 717.7 W/m $\mathrm{m}^{3}$ for strontium and $292.9 \mathrm{~W} / \mathrm{m}^{3}$ for plutonium, giving an overall MST heat source of $1010.7 \mathrm{~W} / \mathrm{m}^{3}$. Recent tests conducted at SRNL have shown that much higher plutonium loadings are possible on MST when very low MST:supernate ratios are used. As a result, calculations were also conducted using twice the calculated MST heat load $\left(2021.4 \mathrm{~W} / \mathrm{m}^{3}\right)$. 


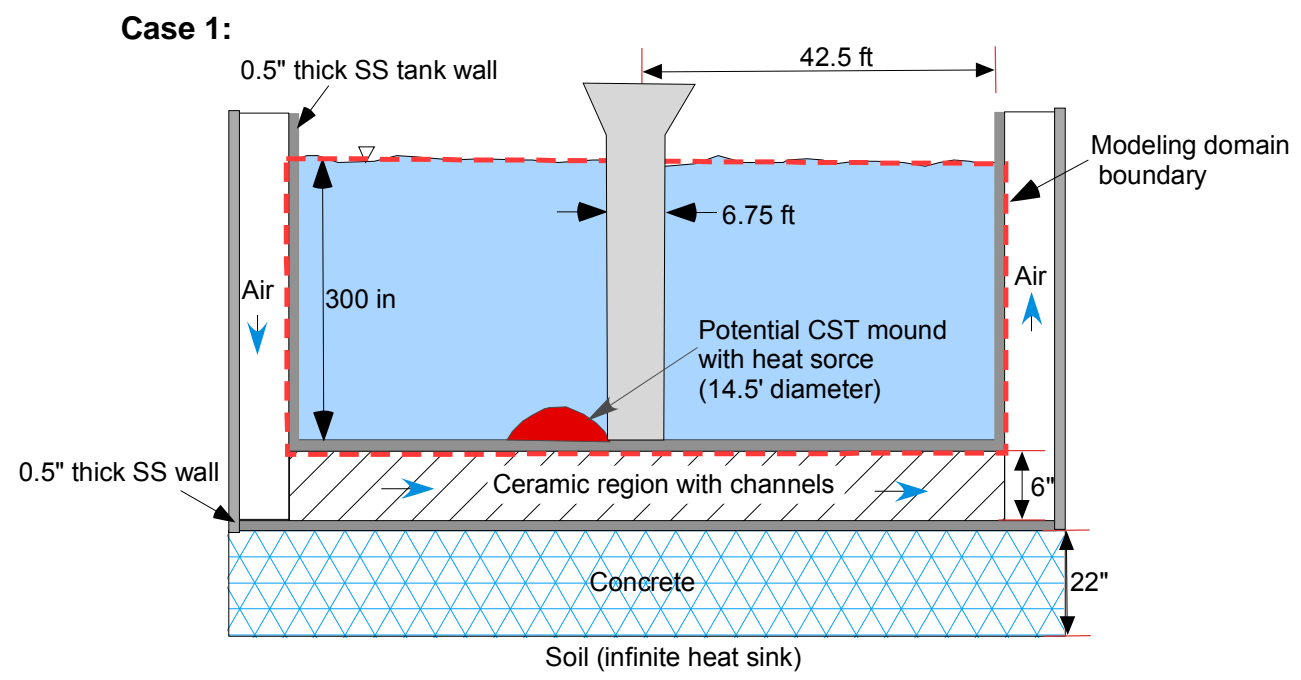

Thermal criteria: Tank wall temperature can not exceed $100^{\circ} \mathrm{C}$.

Figure 7. In-tank column modeling geometry for Case 1 (hemispherical CST mound)

Case 2:

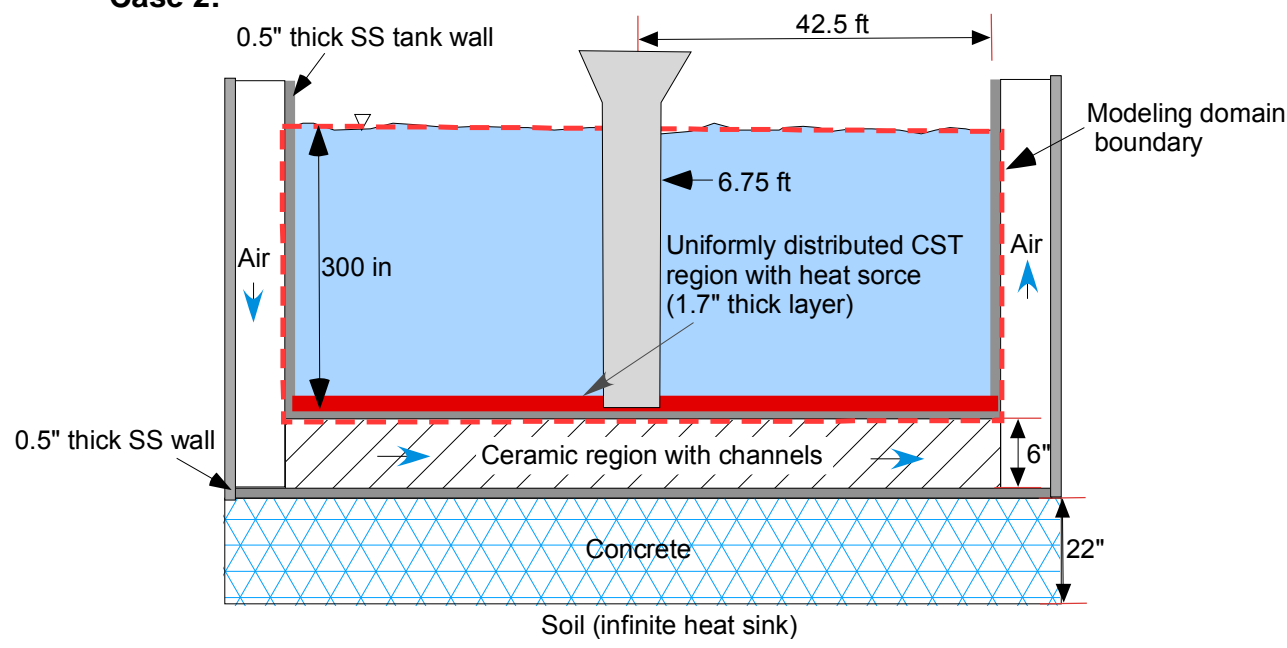

Thermal criteria: Tank wall temperature can not exceed $100^{\circ} \mathrm{C}$.

Figure 8. In-tank column modeling geometry for Case 2 (flat CST layer) 


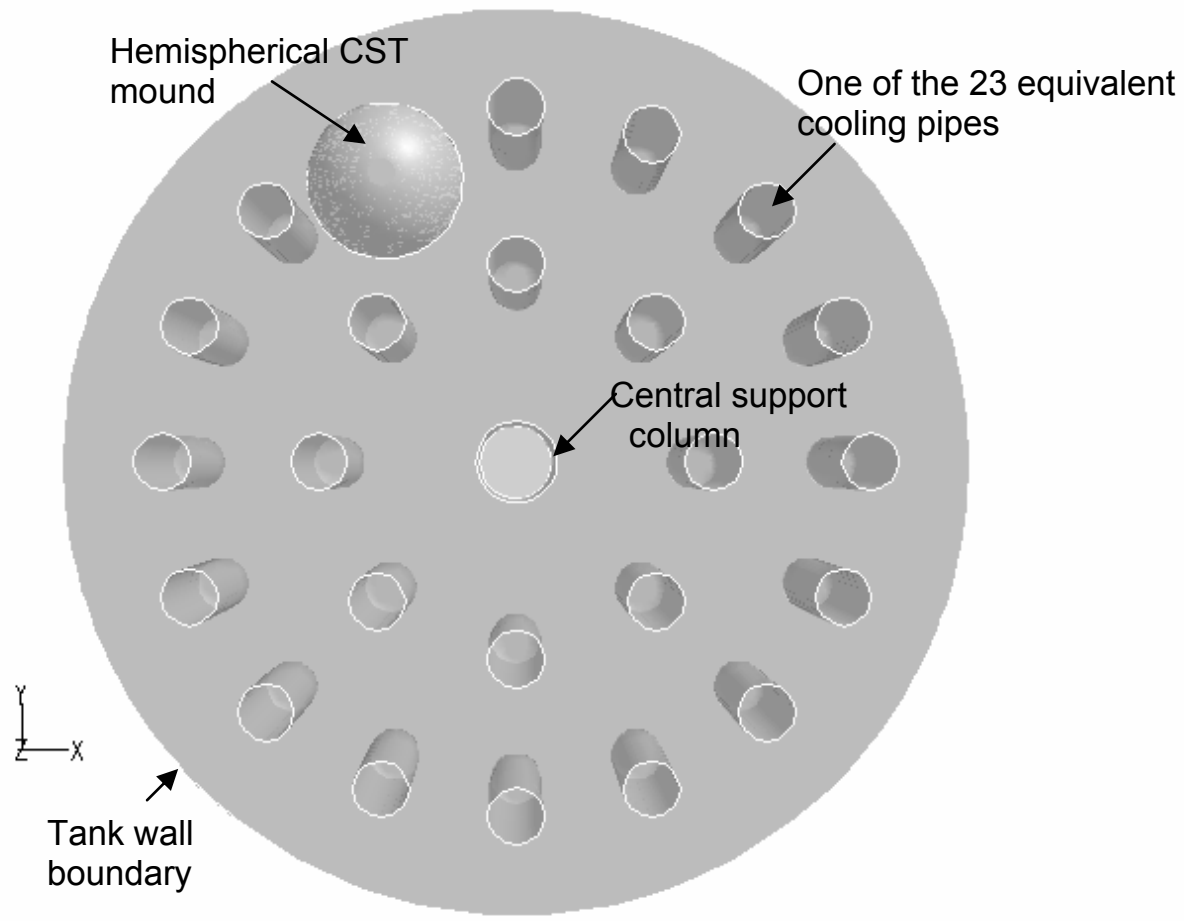

Figure 9. Tank interior computational domain used for the in-tank modeling showing the cooling coils

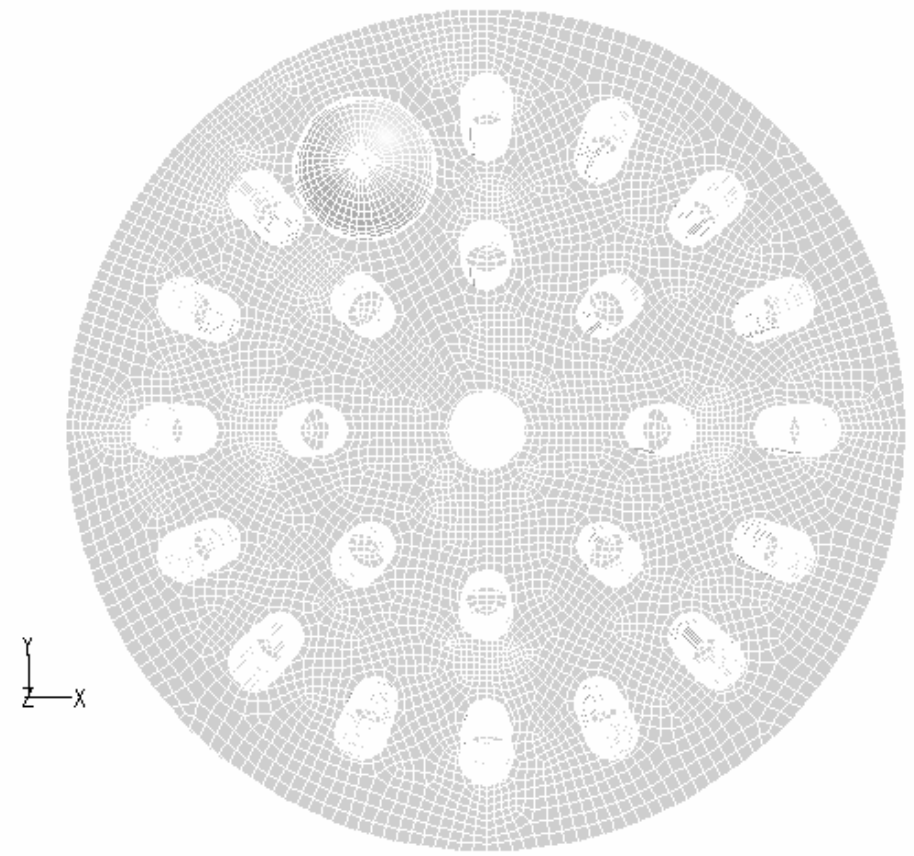

Figure 10. Tank interior computational meshes used for the in-tank modeling 


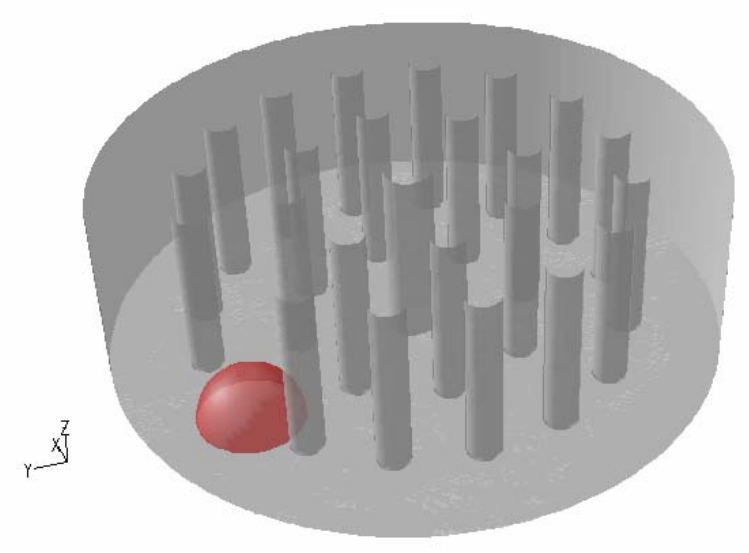

(Case 1)

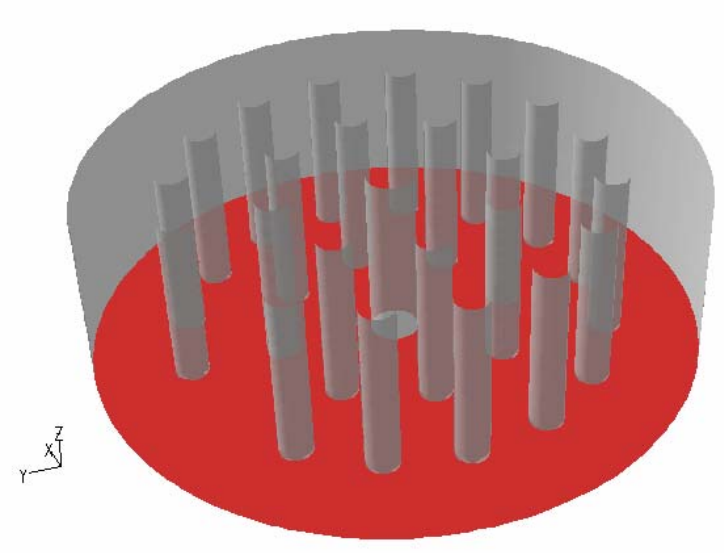

(Case 2)

Figure 11. Computational domains for the hemispherical mound (Case 1) and the flat layer (Case 2) formed by CST accumulation on the tank floor (red indicates CST media)

\subsection{MODELING RESULTS AND DISCUSSION}

The present thermal modeling calculations primarily consist of two modeling domains. One domain involves the in-column heat transfer analysis case shown in Figure 1. The other domain involves the in-tank analysis with CST media on the tank floor shown in Figures 2 and 6 . The established meshes for these corresponding computational domains are shown in Figures 3 and 10, respectively. Material and thermal properties used for the calculations are shown in Table 2. For in-column cases involving stagnant liquid, convective heat transfer mechanisms associated with movement of the mobile liquid phase within the column were assumed to be negligible as a conservative estimate 
of the maximum column temperature. The external wall surfaces of the wet and dry columns were cooled by natural convection coupled with radiation. For the baseline incolumn case, the column was assumed to be cooled by forced convective cooling through the central cooling tube and the four external cooling tubes with natural convection cooling of the remaining column wall portions. Detailed cases for the incolumn evaluations are shown in Table 3. A constant ambient temperature of $35^{\circ} \mathrm{C}$ was assumed for all modeling cases. For both in-column and in-tank modeling, cesium loading on CST was assumed to be $257 \mathrm{Ci} / \mathrm{L}\left(1273\right.$ watts $\left./ \mathrm{m}^{3}\right)$ based on previous analysis which indicated that this was the highest loading for the anticipated feeds. A project decision was then made to utilize a feed qualification program to control the cesium loading to $300 \mathrm{Ci} / \mathrm{L}$. All subsequent thermal modeling assumed this loading value.

The performance model was benchmarked against the theoretical results to verify the computational results against the previous work [3]. The verified model was used for the thermal calculations for the in-column and in-tank models. The thermal analysis and evaluation were made by applying two temperature limits to the modeling domain as safety criteria. The safety criteria for the column and tank wall temperatures are assumed to be 130 and $100^{\circ} \mathrm{C}$, respectively. A temperature limit of $55^{\circ} \mathrm{C}$ for the tank liquid containing the spent CST is also assumed for operational control.

\subsection{IN-COLUMN THERMAL MODELING RESULTS}

For computational modeling purposes, a conservative approach was taken by assuming that the primary cooling mechanisms inside and outside of the column were conduction and natural convection, respectively. Two-dimensional modeling calculations were conducted with the assumption that axial heat removal (end effects) from the column was negligible relative to radial heat transfer as previously discussed.

For the in-column thermal analysis of the 28 -in CST column, $100 \%$ cesium loading, one central cooling and four active external tubes, and $35^{\circ} \mathrm{C}$ ambient temperature were considered to be the baseline conditions. Figure 12 shows the modeling results for the steady-state temperature distributions of the fully-loaded CST column, which is filled with stagnant salt solution. Table 6 shows quantitative comparisons of steady-state maximum temperatures for a range of column conditions. The results indicate that when both the internal and external engineered cooling systems are active and the CST bed is filled with stagnant liquid, the maximum temperature will reach about $63{ }^{\circ} \mathrm{C}$. With inactive central cooling and four active external cooling tubes, the peak temperature is about $114{ }^{\circ} \mathrm{C}$. On the other hand, when only the central cooling system is active, the peak temperature is about $80^{\circ} \mathrm{C}$. When both of the engineered cooling systems are lost, the column temperature increases to about $156^{\circ} \mathrm{C}$. This temperature would not be observed in practice for the wet column until complete supernate volatilization occurs as a result of boiling at a temperature near $130{ }^{\circ} \mathrm{C}$. Radial steady-state temperature distributions for these cases are compared in Figure 13. It is noted that the central cooling tube is particularly effective at cooling the column and results in a decrease in the peak temperature of $76^{\circ} \mathrm{C}$ as compared to the case with no active cooling.

When the CST column loaded with $100 \%$ cesium has $5 \mathrm{gpm}$ solution flow without active cooling, the maximum column temperatures increase only by about 1 to $2{ }^{\circ} \mathrm{C}$ across the column length, depending on the column height (Table 6). Therefore, $5 \mathrm{gpm}$ process fluid flow through the column provides adequate heat removal from the column even with no active cooling. 
Figure 14 compares transient calculation results for the stagnant, wet CST columns with and without active cooling systems. With both internal and external engineered cooling systems inactive, the maximum column temperature increases to above $75^{\circ} \mathrm{C}$ within two days after cooling system loss. The steady-state boiling temperature of $130{ }^{\circ} \mathrm{C}$ is reached in about 6 days. The calculation results are meaningless beyond the supernate boiling temperature. With active cooling the maximum column temperature approaches $60{ }^{\circ} \mathrm{C}$ within 48 hours and the maximum steady-state temperature only reaches $63^{\circ} \mathrm{C}$, as discussed above.

In the case of inadvertent solution leakage from the CST column or bed dryout due to insufficient cooling, there are safety concerns about the rate of transient thermal response of the fully-loaded column and the effectiveness of the cooling system at maintaining the temperature of the dry column. Transient results for the dry column are compared for two different thermal loadings in Figure 15. With a dry column containing a loading of $257 \mathrm{Ci} /$ liter at an initial temperature of $35^{\circ} \mathrm{C}$ and active engineered cooling, a steady-state maximum temperature of $122{ }^{\circ} \mathrm{C}$ is reached in about 3 days. The results show that when the thermal loading is increased by about $17 \%$ (from 257 to $300 \mathrm{Ci} /$ liter), the maximum column temperature increases by about $12 \%$. It is noted that the transient thermal response time of the dry column is much more rapid than that of the wet column (Figure 14), as expected.

Figure 16 compares transient thermal responses with and without the engineered cooling systems for the dry, air-filled column. When the dry column has inactive internal and external cooling systems, the temperature reaches $130^{\circ} \mathrm{C}$ in about 24 hours under $300 \mathrm{Ci} /$ liter thermal loading. The maximum steady-state column temperature for the case with an inactive cooling system of $286^{\circ} \mathrm{C}$ is $150^{\circ} \mathrm{C}$ higher than that for the actively cooled case $\left(136^{\circ} \mathrm{C}\right)$. Figure 17 compares steady-state temperature distributions for the dry and wet columns under the same color scale without active internal or external cooling. The peak temperature for the wet column is about $110^{\circ} \mathrm{C}$ lower that that of the dry column. Figure 18 compares the steady-state temperature distributions along the radial direction for the dry column with and without active cooling. It is noted that the internal cooling system provides a particularly effective cooling mechanism under the dry CST column condition, as was the case for the wet column. Quantitative comparisons for a range of different cases evaluated for the wet and dry columns are provided in Table 7. The results demonstrate that the dry CST column temperature will be no higher than $286{ }^{\circ} \mathrm{C}$ under the worst case conditions with no active cooling.

For the case where forced air flow through the dry bed is used to cool the column, the results show that air flow through the bed has a large impact on the maximum bed temperature. Table 8 shows steady-state maximum column temperatures for various operating conditions of the dry CST column with and without air flow. The maximum bed temperature is estimated to be less than $100{ }^{\circ} \mathrm{C}$ with 80 cubic feet per minute air flow (4 inch/sec velocity) through the column.

Sensitivity analysis was performed for different operating conditions. Table 9 shows the steady-state maximum temperatures for different ambient temperatures and thermal loadings with active engineered cooling for the dry column case. With active cooling, when the column heat load was increased by about $17 \%$ from the $257 \mathrm{Ci} /$ liter baseline value, the maximum column temperature increased by about $14{ }^{\circ} \mathrm{C}$. Increasing the ambient temperature from 35 to $55{ }^{\circ} \mathrm{C}$ resulted in small increases in the maximum column temperature of $<4{ }^{\circ} \mathrm{C}$. Maximum column temperatures were also estimated for 
different coolant water temperatures with active engineered cooling. Table 10 compares the steady-state maximum column temperatures for two different coolant temperatures, 25 and $35^{\circ} \mathrm{C}$. The calculation results show that when the coolant temperature increases by $10^{\circ} \mathrm{C}$, maximum column temperature changes by about $6{ }^{\circ} \mathrm{C}$. Table 11 shows the steady-state maximum temperatures for the dry column case with different ambient and heat loading conditions without active engineered cooling. As shown in the table, a 20 ${ }^{\circ} \mathrm{C}$ increase from the baseline ambient temperature of $35{ }^{\circ} \mathrm{C}$, results in a maximum column temperature increase of only about $8^{\circ} \mathrm{C}$. The sensitivity analysis indicates that varying these parameters within the expected range of possible conditions does not greatly impact the calculated maximum column temperatures.

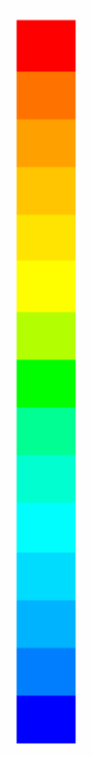
$6.27 e+\square 1$
$6.02 e+01$
$5.77 e+01$
$5.52 e+01$
$5.28 \mathrm{e}+01$
$5.03 \mathrm{e}+01$
$4.78 e+01$
$4.53 e+01$
$4.29 e+01$
$4.04 e+[1$
$3.79 \mathrm{e}+\square 1$
$3.54 \mathrm{e}+01$
$3.30 e+01$
$3.05 \mathrm{e}+01$
$2.80 e+01$
$2.55 \mathrm{e}+\square 1$

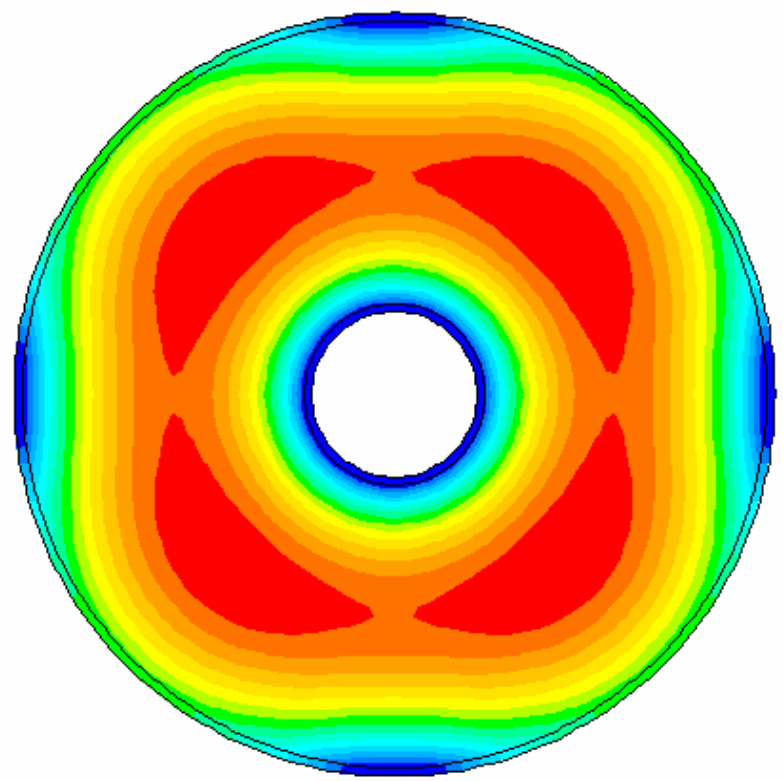

Figure 12. Steady-state temperature distributions for the ion-exchange column with wet CST media under baseline conditions (257 C/L) 

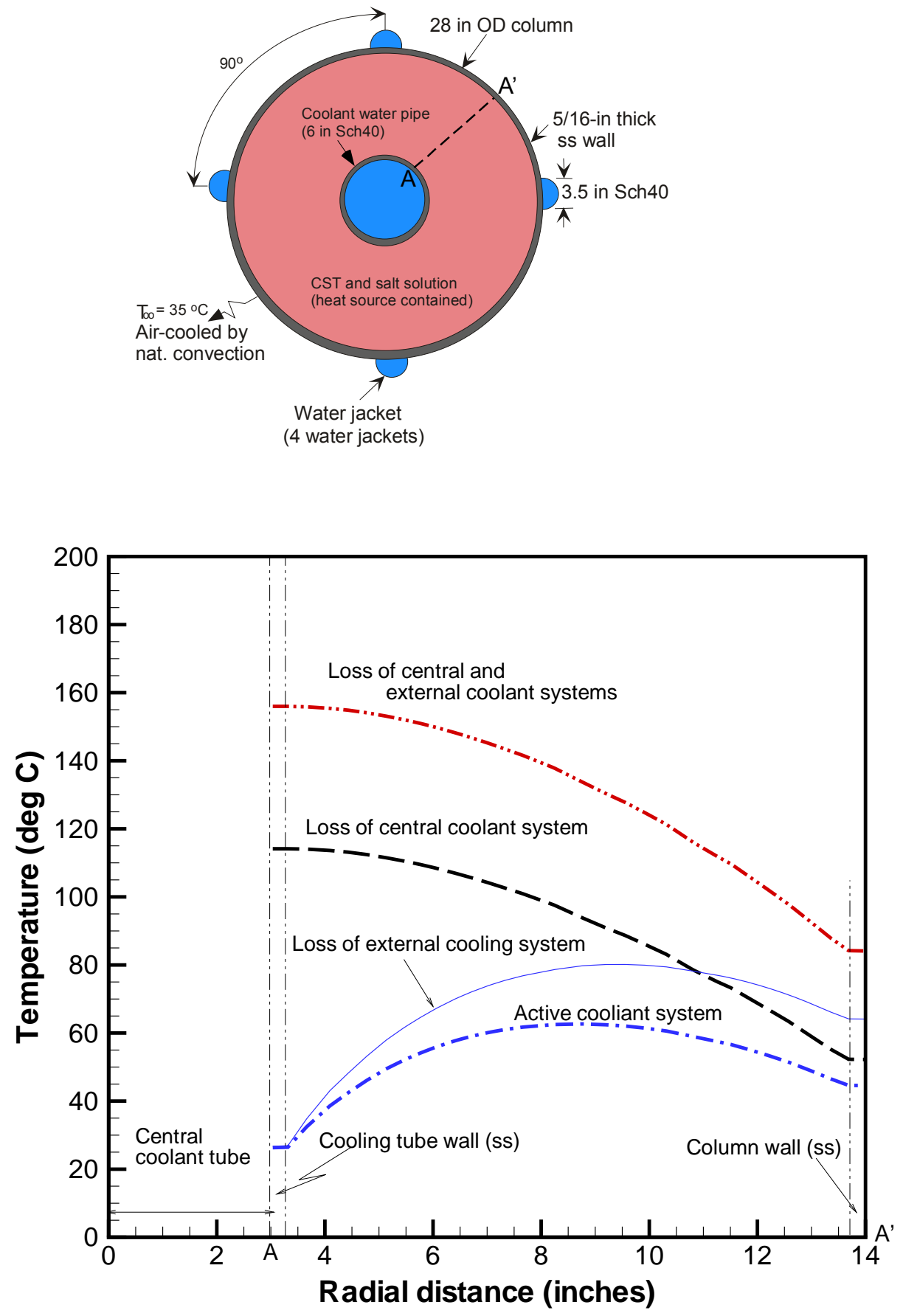

Figure 13. Steady-state column temperature profile along the radial line A-A' for stagnant wet CST media with active and inactive coolant systems $(257 \mathrm{Ci} / \mathrm{L})$ 
Table 6. Steady-state maximum column temperatures for various conditions for the wet column

\begin{tabular}{|c|c|c|c|c|}
\hline $\begin{array}{l}\text { Column } \\
\text { Hydraulic } \\
\text { conditions }\end{array}$ & $\begin{array}{c}\text { Central cooling } \\
\text { system }\end{array}$ & $\begin{array}{c}\text { External } \\
\text { cooling system }\end{array}$ & $\begin{array}{c}100 \% \text { CST loading } \\
\text { (Curie/liter) }\end{array}$ & $\begin{array}{c}\text { Max. column } \\
\text { temperature }\left({ }^{\circ} \mathrm{C}\right)^{*}\end{array}$ \\
\hline \multirow{3}{*}{$5 \mathrm{gpm}$ flow } & Inactive & Inactive & 257 & 36.1 for $10 \mathrm{ft} \mathrm{high} \mathrm{col}$. \\
\hline & Inactive & Inactive & 257 & 36.7 for $15 \mathrm{ft} \mathrm{high} \mathrm{col.}$ \\
\hline & Inactive & Inactive & 257 & $37.8 \mathrm{for} 25 \mathrm{ft}$ high col. \\
\hline Stagnant & Active & Active & 257 & 62.7 \\
\hline Stagnant & Active & Inactive & 257 & 80.2 \\
\hline Stagnant & Inactive & Active & 257 & 114.1 \\
\hline Stagnant & Inactive & Inactive & 257 & 156.0 \\
\hline
\end{tabular}

${ }^{*}$ based on $35^{\circ} \mathrm{C}$ inlet temperature

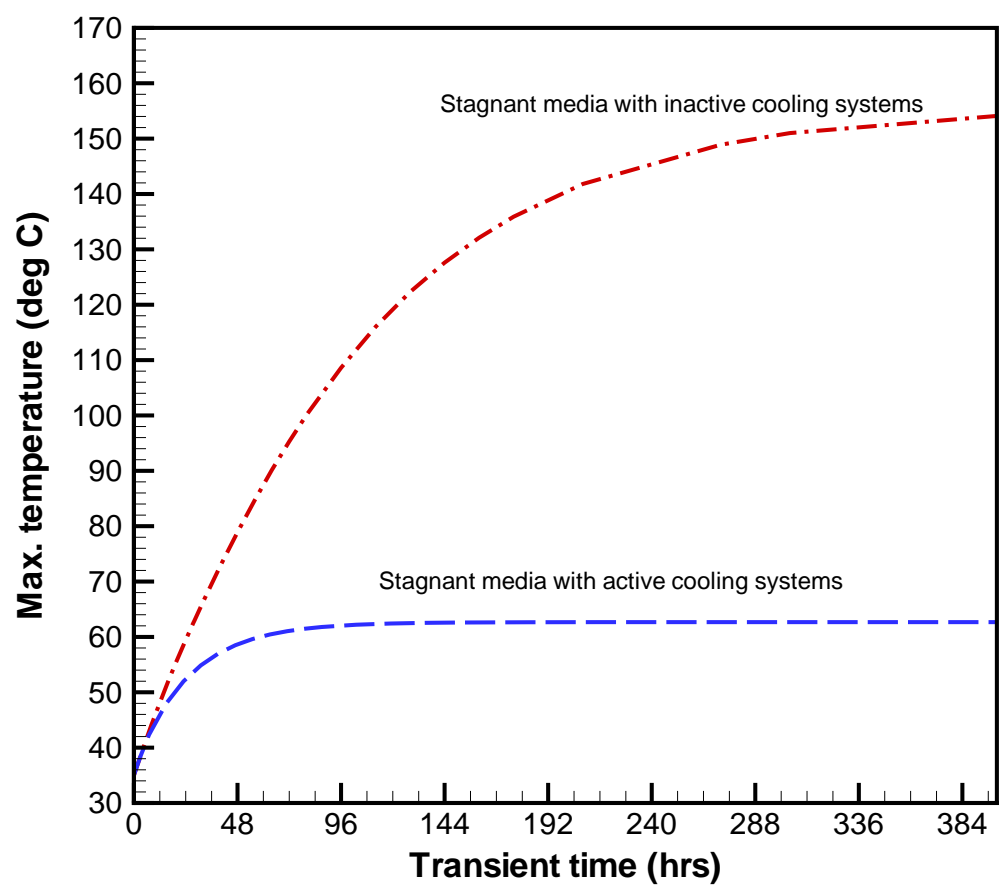

Figure 14. Transient maximum column temperatures for stagnant, wet CST media with active and inactive coolant systems 


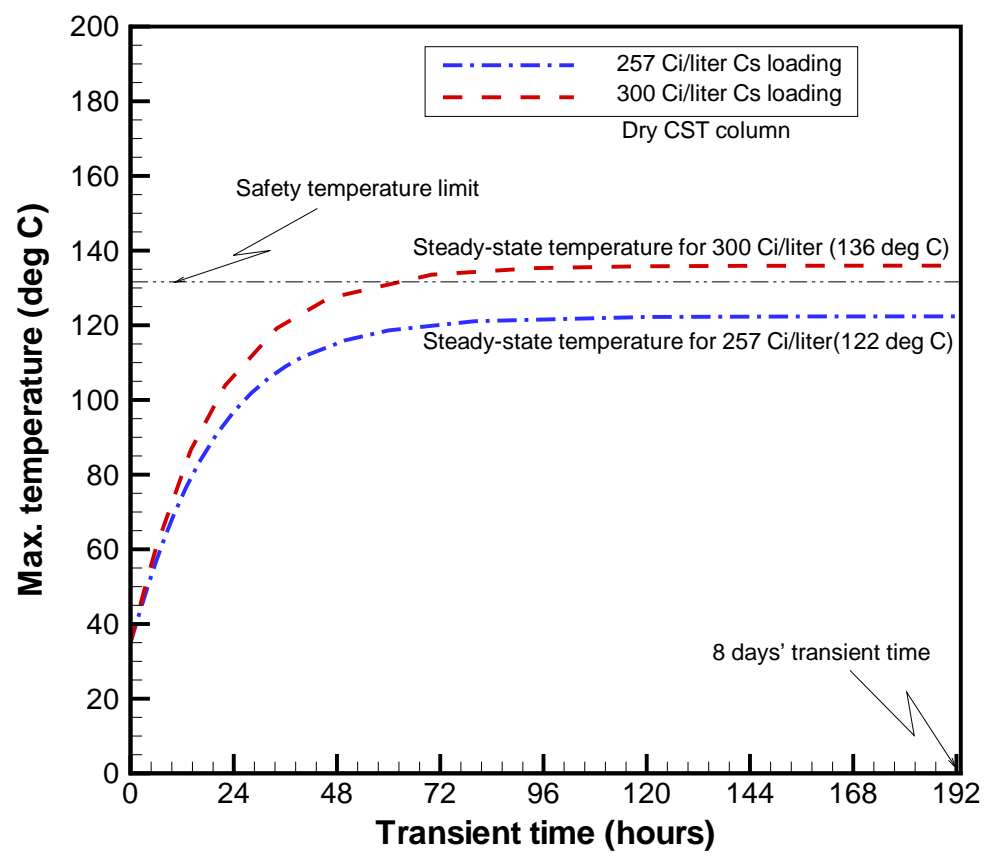

Figure 15. Transient responses of maximum column temperatures to the inadvertent loss of process fluid (dry column case) with active internal and external cooling systems (257 vs. $300 \mathrm{Ci} / \mathrm{L}$ )

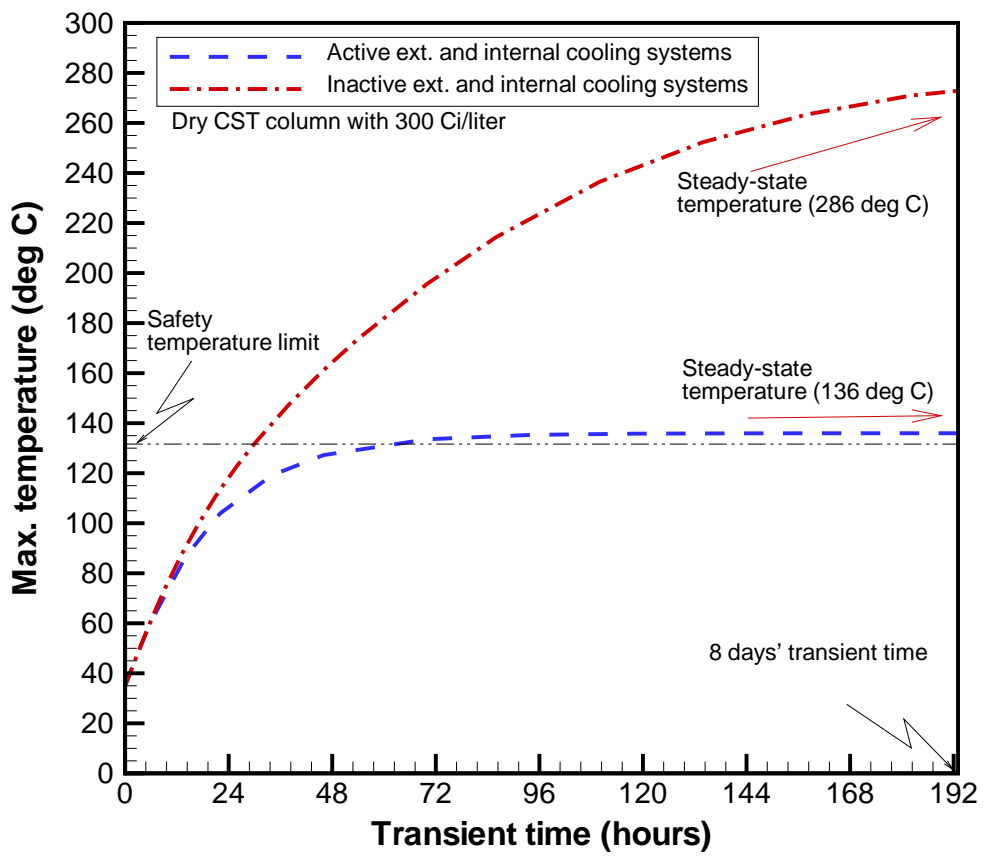

Figure 16. Comparison of transient responses of maximum column temperatures with and without active cooling for the dry column case $(300 \mathrm{Ci} / \mathrm{L})$ 


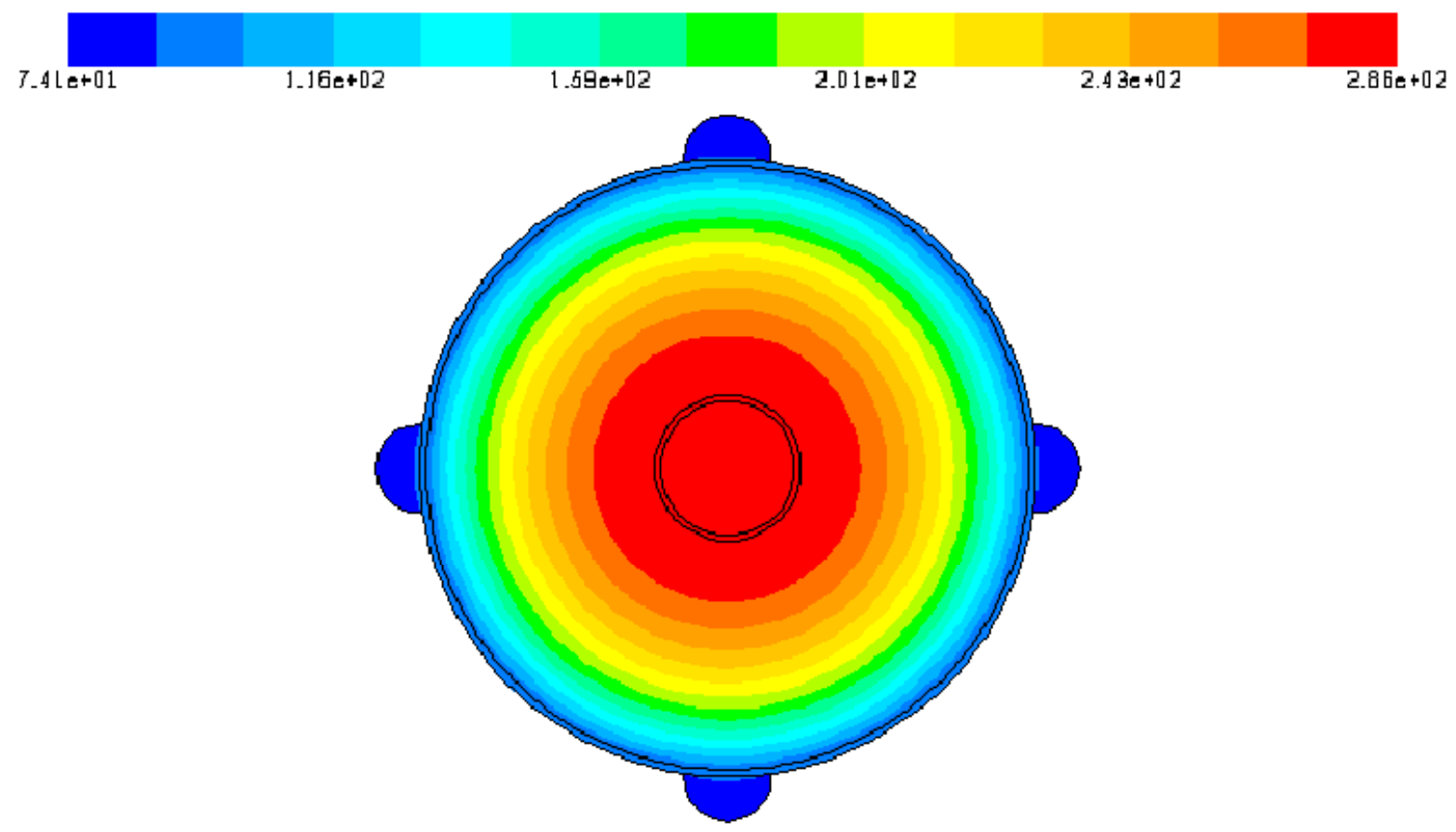

(Dry column)

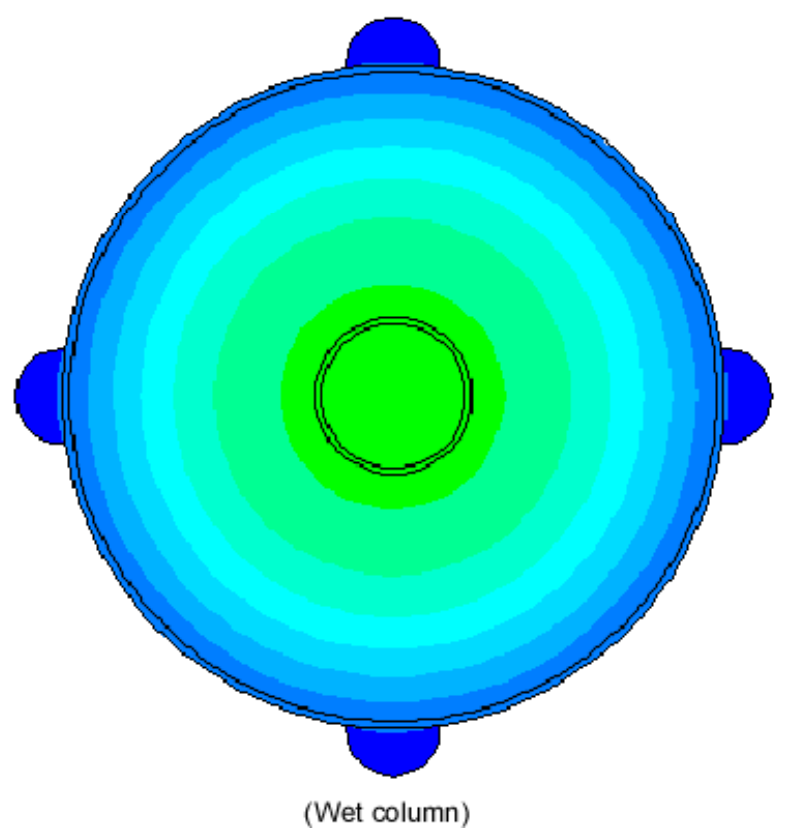

Figure 17. Comparison of temperature distributions between dry and wet CST columns with inactive internal and external cooling (Red color indicates $286^{\circ} \mathrm{C}$; Loading: 300 $\mathrm{Ci} / \mathrm{L})$. 

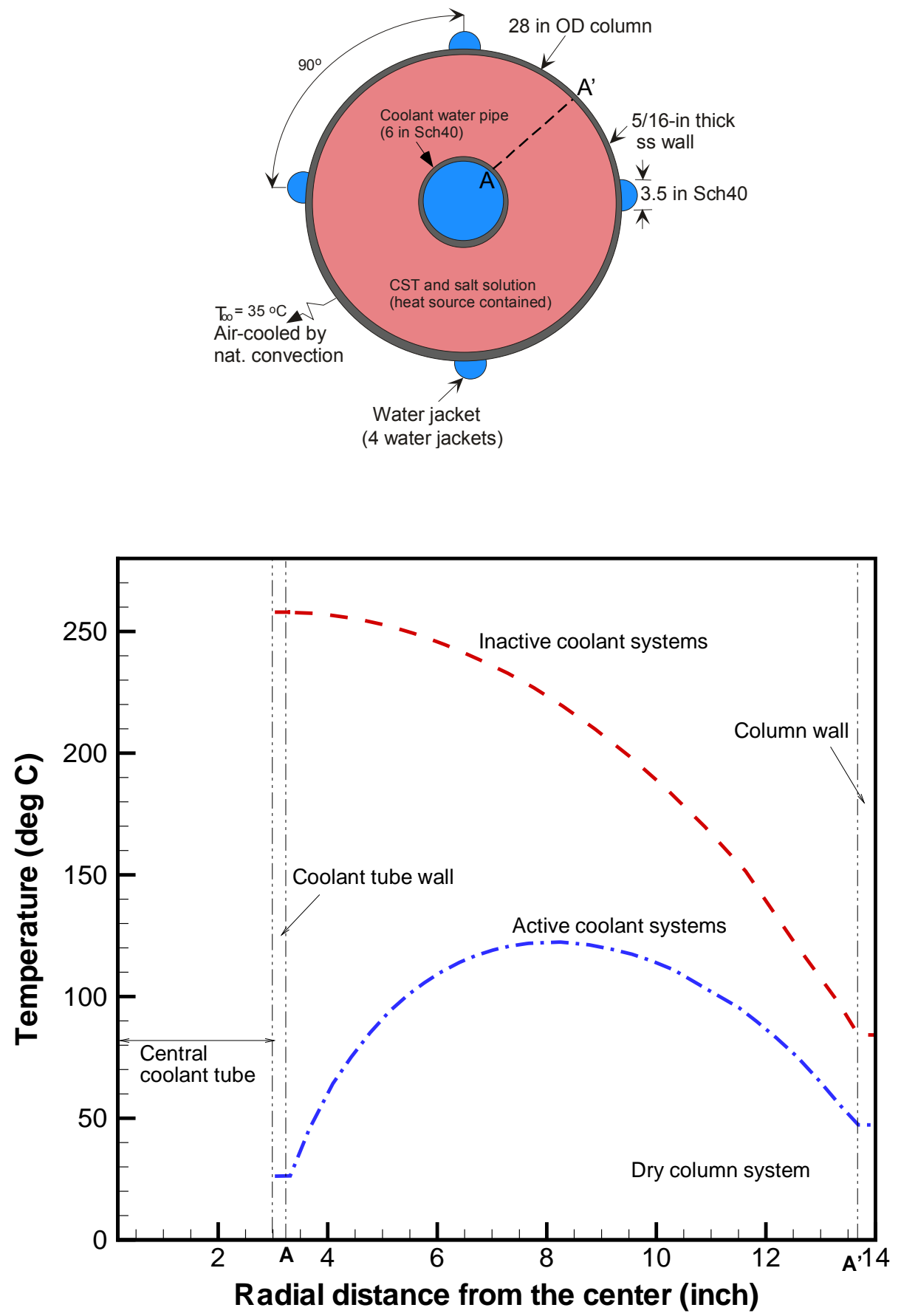

Figure 18. Comparison of temperatures along the radial distance A-A' between the active and inactive coolant systems for the dry column case $(300 \mathrm{Ci} / \mathrm{L})$ 
Table 7. Steady-state maximum column temperatures for various conditions

\begin{tabular}{|c|c|c|c|c|}
\hline $\begin{array}{c}\text { Column } \\
\text { Hydraulic } \\
\text { conditions }\end{array}$ & $\begin{array}{c}\text { Central cooling } \\
\text { system }\end{array}$ & $\begin{array}{c}\text { External } \\
\text { cooling system }\end{array}$ & $\begin{array}{c}100 \% \text { CST loading } \\
\text { (Curie/liter) }\end{array}$ & $\begin{array}{c}\text { Max. column } \\
\text { temperature }\left({ }^{\circ} \mathrm{C}\right)^{*}\end{array}$ \\
\hline $\begin{array}{c}\text { Stagnant } \\
\text { (Wet) }\end{array}$ & Active & Active & 257 & 62.7 \\
\hline $\begin{array}{c}\text { Stagnant } \\
\text { (Wet) }\end{array}$ & Inactive & Inactive & 257 & 156.0 \\
\hline $\begin{array}{c}\text { Stagnant } \\
\text { (Dry) }\end{array}$ & Active & Active & 257 & 257.9 \\
\hline $\begin{array}{c}\text { Stagnant } \\
\text { (Dry) }\end{array}$ & Inactive & Inactive & 257 & 68.6 \\
\hline $\begin{array}{c}\text { Stagnant } \\
\text { (Wet) }\end{array}$ & Active & Active & 300 & 175.0 \\
\hline $\begin{array}{c}\text { Stagnant } \\
\text { (Wet) }\end{array}$ & Inactive & Inactive & 300 & 136.0 \\
\hline $\begin{array}{c}\text { Stagnant } \\
\text { (Dry) }\end{array}$ & Active & Active & 300 & 285.8 \\
\hline $\begin{array}{c}\text { Stagnant } \\
\text { (Dry) }\end{array}$ & Inactive & Inactive & 300 & \\
\hline \multirow{2}{*}{${ }^{\text {(Wrive }}$} & on 35 ${ }^{\circ} \mathrm{C}$ ambient temperature & \\
\hline
\end{tabular}

Table 8. Additional steady-state maximum column temperatures for the dry column case with and without coolant air flow

\begin{tabular}{|c|c|c|c|c|}
\hline $\begin{array}{c}\text { Column Hydraulic } \\
\text { conditions }\end{array}$ & $\begin{array}{c}\text { Central cooling } \\
\text { system }\end{array}$ & $\begin{array}{c}\text { External } \\
\text { cooling system }\end{array}$ & $\begin{array}{c}100 \% \text { CST loading } \\
\text { (Curie/liter) }\end{array}$ & $\begin{array}{c}\text { Max. column } \\
\text { temperature }\left({ }^{\circ} \mathrm{C}\right)^{*}\end{array}$ \\
\hline $\begin{array}{c}2 \text { inch/sec air } \\
\text { (40 SCFM air flow) }\end{array}$ & Inactive & Inactive & 257 & 151.4 \\
\hline $\begin{array}{c}4 \text { inch/sec air } \\
(80 \text { SCFM air flow) }\end{array}$ & Inactive & Inactive & 257 & 93.2 \\
\hline Stagnant (Dry) & Inactive & Inactive & 257 & 257.9 \\
\hline
\end{tabular}

${ }^{*}$ based on $35^{\circ} \mathrm{C}$ inlet and ambient temperatures 
Table 9. Steady-state maximum column temperatures for different ambient temperature and thermal loadings with active engineered cooling (sensitivity studies)

\begin{tabular}{|c|c|c|c|c|}
\hline $\begin{array}{c}\text { Column } \\
\text { Hydraulic } \\
\text { conditions }\end{array}$ & $\begin{array}{c}\text { Central/Ext. } \\
\text { cooling } \\
\text { systems }\end{array}$ & $\begin{array}{c}\text { Ambient } \\
\text { temperature } \\
\left({ }^{\circ} \mathrm{C}\right)\end{array}$ & $\begin{array}{c}100 \% \text { CST loading } \\
\text { (Curie/liter) }\end{array}$ & $\begin{array}{c}\text { Max. column } \\
\text { temperature }\left({ }^{\circ} \mathrm{C}\right)\end{array}$ \\
\hline $\begin{array}{c}\text { Stagnant } \\
\text { (Dry) }\end{array}$ & Active & 35 & 257 & 122.4 \\
\hline $\begin{array}{c}\text { Stagnant } \\
\text { (Dry) }\end{array}$ & Active & 55 & 257 & 125.5 \\
\hline $\begin{array}{c}\text { Stagnant } \\
\text { (Dry) }\end{array}$ & Active & 35 & 300 & 136.0 \\
\hline $\begin{array}{c}\text { Stagnant } \\
\text { (Dry) }\end{array}$ & Active & 55 & 300 & 139.0 \\
\hline
\end{tabular}

Table 10. Steady-state maximum column temperatures for different ambient and coolant water temperatures with active engineered cooling (sensitivity studies)

\begin{tabular}{|c|c|c|c|c|c|}
\hline $\begin{array}{c}\text { Column } \\
\text { Hydraulic } \\
\text { conditions }\end{array}$ & $\begin{array}{c}\text { Central/Ext. } \\
\text { cooling } \\
\text { systems }\end{array}$ & $\begin{array}{c}\text { Ambient } \\
\text { temperature } \\
\left({ }^{\circ} \mathrm{C}\right)\end{array}$ & $\begin{array}{c}\text { Coolant } \\
\text { temperature } \\
\left({ }^{\circ} \mathrm{C}\right)\end{array}$ & $\begin{array}{c}100 \% \text { CST } \\
\text { loading } \\
(\text { Curie/liter })\end{array}$ & $\begin{array}{c}\text { Max. column } \\
\text { temperature }\left({ }^{\circ} \mathrm{C}\right)\end{array}$ \\
\hline $\begin{array}{c}\text { Stagnant } \\
\text { (Dry) }\end{array}$ & Active & 55 & 25 & 257 & 125.5 \\
\hline $\begin{array}{c}\text { Stagnant } \\
\text { (Dry) }\end{array}$ & Active & 55 & 35 & 257 & 131.6 \\
\hline
\end{tabular}


Table 11. Steady-state maximum column temperatures for various column operating conditions without engineered cooling (sensitivity studies)

\begin{tabular}{|c|c|c|c|c|}
\hline $\begin{array}{c}\text { Column } \\
\text { Hydraulic } \\
\text { conditions }\end{array}$ & $\begin{array}{c}\text { Central/Ext. } \\
\text { cooling } \\
\text { systems }\end{array}$ & $\begin{array}{c}\text { Ambient } \\
\text { temperature } \\
\left({ }^{\circ} \mathrm{C}\right)\end{array}$ & $\begin{array}{c}100 \% \text { CST loading } \\
\text { (Curie/liter) }\end{array}$ & $\begin{array}{c}\text { Max. column } \\
\text { temperature }\left({ }^{\circ} \mathrm{C}\right)\end{array}$ \\
\hline $\begin{array}{c}\text { Stagnant } \\
\text { (Dry) }\end{array}$ & Inactive & 35 & 257 & 257.9 \\
\hline $\begin{array}{c}\text { Stagnant } \\
\text { (Dry) }\end{array}$ & Inactive & 55 & 300 & 287.1 \\
\hline $\begin{array}{c}\text { Stagnant } \\
\text { (Dry) }\end{array}$ & Inactive & 35 & 300 & 293.4 \\
\hline $\begin{array}{c}\text { Stagnant } \\
\text { (Dry) }\end{array}$ & Inactive & 55 & 305.8 \\
\hline
\end{tabular}

\subsection{IN-TANK THERMAL MODELING RESULTS}

For the in-tank evaluations, the modeling approach changed as the work progressed based on the results. Initial modeling efforts involved an adiabatic tank floor with no heat transfer into the soil region and unground CST media with a loading of $257 \mathrm{Ci} / \mathrm{L}$. Due to the high temperatures observed for various modeling cases assuming an adiabatic floor, a new modeling domain was developed which included the soil region below the tank. Subsequent analysis revealed that a significant amount of heat transfer occurred through the floor, which impacted the calculated maximum floor temperatures. Assuming ground versus unground CST media was also found to significantly impact the results since grinding is believed to result in an increase in the volumetric heat load of approximately $100 \%$ (i.e. a 1 inch layer of ground CST on the tank floor contains twice as much cesium as a 1 inch layer of unground material). Later calculations therefore focused on ground material. Finally, initial calculations assumed the same cesium loading $(257 \mathrm{Ci} / \mathrm{L})$ used in previous evaluations. However, during this work the SCIX project selected a higher loading of $300 \mathrm{Ci} / \mathrm{L}$, which is based on the implementation of a feed qualification program to limit the CST loading level. Latter calculations used the $300 \mathrm{Ci} / \mathrm{L}$ limit. Not surprisingly, this modest increase in loading did not result in large increases in the maximum column temperatures. Therefore, all modeling cases were not repeated with the higher loading. Rather selected comparative cases were conducted.

For the in-tank thermal modeling analysis, a spent CST mound with $100 \%$ cesium loading with active cooling through the cooling tubes inside Tank 41 was considered to be the baseline condition. In all cases, forced convection mixing effects that would be expected as a result of operation of the submersible jet mixer pumps in the tank were assumed to be negligible for conservatism. The external wall surfaces of the $85-\mathrm{ft}$ diameter tank boundary were cooled by natural convection coupled with radiation, neglecting air ventilation effects around the tank. A constant ambient temperature of 35 ${ }^{\circ} \mathrm{C}$ was assumed. Calculations generally involved the determination of steady-state 
temperatures except for selected cases where transient calculations were conducted. Table 12 shows the two initial cases for the in-tank model involving a hemispherical mound and a pancake layer of unground CST media on the tank floor. These two geometries represent the media distribution extremes, with the hemispherical mound being the worst distribution and the layer being the idealized and best distribution. When the cooling capability is assumed to be uniform over the entire surface area of the 6000gallon CST mound with an adiabatic bottom surface, heat flux for the flat layer (Case 2) is 55 watts $/ \mathrm{m}^{2}$, which is about 17 times less than that of the hemispherical mound (Case 1) as compared in Table 12. This indicates that the hemispherical mound shape provides a conservative estimate of the maximum temperature.

Figure 19 shows transient maximum temperatures observed at two observation points located at the top and bottom surfaces of a hemispherical 6000-gallon mound of unground CST formed under Riser G of Tank $41 \mathrm{H}$. Point A is located at the top surface of the mound and Point $B$ is the located on the tank floor just below the bottom surface of the mound. For these initial calculations, it was assumed the bottom tank surface was adiabatic as a conservative estimate. The results show that the maximum surface temperature of the hemispherical mound reaches about $350{ }^{\circ} \mathrm{C}$ after 12 days, which exceeds the $100{ }^{\circ} \mathrm{C}$ wall temperature limit as well as the solution boiling point. In reality, solution boiling would not allow the system to exceed a temperature of about $130{ }^{\circ} \mathrm{C}$, as discussed earlier. However, as discussed in previous sections, the model assumes a single phase solution. Despite this limitation, the results indicate that a 6,000 gallon hemispherical mound of spent CST would cause significant problems with regard to tank temperature control. Transient snapshots for flow patterns and temperature distributions at 50 hours for this modeling case are presented in Figure 20. The figure shows that the maximum mound surface temperature and the maximum upward fluid velocity driven by buoyancy effects are about $61^{\circ} \mathrm{C}$ and 0.6 inches/sec, respectively.

As discussed earlier, the cooling surface area per unit volume for the flat layer (Case 2) was found to be about 17 times larger than that of hemispherical mound. Figure 21 shows steady-state results for flow patterns and temperature distributions for Case 2 (unground CST), showing that the maximum tank wall surface temperature reaches about $40^{\circ} \mathrm{C}$ for a dispersed 6000 gallon CST layer with a height of 1.7-in. In this case the maximum wall surface temperature is far less than the $100^{\circ} \mathrm{C}$ tank temperature limit. This result emphasizes the dramatic impact that effective mixing and dispersion of the spent CST have on the maximum system temperatures. Table 12 summarizes the transient calculation results for these two basic initial cases for the in-tank domain. The modeling results for Case 1 indicate that the bottom surface temperature reaches the $100{ }^{\circ} \mathrm{C}$ wall temperature limit after 62 hours and the local fluid temperature reaches the $55^{\circ} \mathrm{C}$ fluid temperature after 83 hours. The calculated Case 1 steady-state temperature of $\sim 1800{ }^{\circ} \mathrm{C}$ is not meaningful or expected because supernate boiling will limit the solution temperature to near $130{ }^{\circ} \mathrm{C}$ [19]. As shown in the table, the maximum wall temperature for the 6000-gallon flat layer (Case 2) never reaches either temperature limit.

For the 6,000 gallon flat layer case involving unground CST, which corresponds to 1.7 inch of material, additional calculations were conducted to evaluate the impact of the tank liquid level on the results. Decreasing the tank liquid level from 300 to 9 inches corresponds to a supernate volume change from approximately one million to 32,000 gallons. Calculation results for the reduced supernate volume case are included in Table 13. The results reveal that the tank bottom temperature is not sensitive to this large volume change because 32,000 gallons of liquid still serves as a large heat sink for 6000 gallons of CST. In addition, at this liquid height adequate contact still remains between the liquid and the cooling coils, which serve as the primary heat transfer 
mechanism for the system. Based on these results, no additional calculations were conducted with low tank liquid levels.

Additional transient modeling calculations were conducted for the hemispherical mound using lower total spent unground CST volumes of 900 and 450 gallons. Figure 22 shows the transient temperature results for these cases along with the 6,000 gallon case at two observation points located at the top and bottom mound surfaces. As shown in the figure, the temperature results during the first five days indicate that when the bottom surface of the hemispherical CST mound is assumed to be adiabatic, the $100{ }^{\circ} \mathrm{C}$ wall temperature limit is reached in 2.5 to 3 days for all cases. Table 14 summarizes the transient results for the three different CST mound volumes evaluated. A hemispherical mound is likely the worst geometrical shape possible because it involves the smallest ratio of cooling surface area to mound volume. A hemispherical shape is also an idealized shape that might be expected to form from the transport of the CST material to the tank floor. A flatter geometrical shape is probably more likely to be observed. Therefore, other geometrical shapes with larger aspect ratios were considered for intank modeling. Specifically, cylindrical shapes with various aspect ratios were evaluated. The cylindrical shape may be more representative of the mound shape formed on the tank floor, although the actual shape will likely be between the various idealized geometries considered.

Changing the CST mound shape from a hemispherical geometry with a 37 -in radius to a cylindrical shape with a 6-in height and the same mound volume (450 gallons), decreases the maximum steady-state temperature to $81^{\circ} \mathrm{C}$, which is dramatically lower than the maximum value observed for the hemispherical mound and below the tank wall temperature limit. Table 15 compares the transient results for the CST mound shapes in a quantitative way. When the aspect ratio of the cylindrical mound becomes larger and the cylinder height approaches that of the hemispherical mound, the maximum wall surface temperature also approaches that observed for the hemispherical shape. Comparisons of the maximum steady-state wall temperatures observed for the hemispherical mound and the various cylindrical mounds are provided graphically in Figure 23.

Thermal calculations were also performed for two different cylindrical mound volumes of the same height (6-in). The temperature distributions for the tank wall region for the two cylindrical mounds with volumes of 450 and 4200 gallons with the same 6 inch height are shown in Figures 24 and 25, respectively, and quantitative results are provided in Table 16. The results show that the maximum temperature for the bottom surface of the cylindrical CST mound increases by only about $1{ }^{\circ} \mathrm{C}$ for the larger volume mound. This comparison for two mounds with dramatically different volumes reveals that heat transfer from the mound is primarily vertical for high aspect ratio mound geometries. As a result, the maximum wall temperatures are primarily determined by the mound height, with minimal impacts from the mound width and total volume. This result emphasizes the importance of thoroughly distributing the CST on the tank floor with minimal mounds or piles of material.

The previous in-tank modeling efforts assumed no heat transfer across the tank bottom surface (adiabatic) as an initial conservative estimate. However, based on the results it was believed that the adiabatic heat transfer assumption for the tank bottom surface resulted in unrealistically conservative estimates of the maximum tank floor temperatures. The 0.5 -in thick carbon steel tank bottom wall with multiple lower layers of ceramic and concrete were expected to provide significant heat transfer to the soil region which behaves as in infinite heat sink. Floor heat transfer was also expected to significantly impact the results because this heat transfer mechanism is operative in the 
exact location of interest as far as the maximum tank temperatures are concerned. Based on previous work [4], a 150-foot deep soil region below the tank bottom was expected to provide sufficient depth and heat transfer volume to reach thermal equilibrium at an assumed soil temperature of $20{ }^{\circ} \mathrm{C}$. A schematic of the modified calculation domain including the various known material layers and a 150 foot soil region below the tank is shown along with results in Table 17 . When heat transfer across the tank floor is allowed, significantly reduced maximum floor temperatures are observed. A quantitative comparison of maximum tank bottom surface temperatures is provided in Table 17 between the cases with and without floor heat transfer for three different cylindrical CST mound heights. With the floor heat transfer mechanism included, the temperature limit of $100{ }^{\circ} \mathrm{C}$ is not exceeded even for a 12 inch high cylindrical mound (900 gallon volume). As discussed above, it is expected that the total volume has little impact on the maximum temperature and the key parameter is the height of the mound. Therefore, larger mound volumes of this same height would also be expected to result in acceptable maximum temperatures. Figure 26 shows a comparison of vertical temperature profiles between the two models with and without heat transfer through the tank bottom for a 12-in high cylindrical mound located on the tank floor. This result graphically demonstrates the dramatic impact of floor heat transfer on the maximum wall temperature. It is also noted that when the heat transfer across the tank bottom is considered, the location of the maximum temperature within the mound changes from near the bottom of the mound to the center of the mound.

The previous in-tank calculations were conducted assuming that the spent CST particles were uniform in size with typical diameter and packing characteristics for unground, asreceived CST media. However, the spent CST media may be ground prior to transfer to the tank floor. It is expected that grinding of the material will result in a volume reduction and a change in porosity resulting from the generation of non-uniform particle size and shape distributions during the grinding process. Broadening of the particle distribution is expected to result in reduced porosity resulting from space filling of smaller particles within the voids between the larger particles as illustrated in Figure 27. Based on estimations from the literature [17,18, and 20], the void volume of the CST mound was estimated to be reduced by $50 \%$ after grinding. Thermal modeling calculations were conducted using porosity and loading values believed to be representative of the ground material. For these cases, the volumetric heat load was twice the value used for the unground material. It was therefore expected that the maximum floor temperatures observed with the ground material would be higher than were calculated for comparable geometries of unground media. Table 18 quantitatively compares the maximum tank bottom surface temperatures calculated for 6- and 9-inch high cylindrical mounds of ground and unground CST media using both in-tank models. Given the above assumptions, 450 gallons of ground CST corresponds to a volume equivalent to two SCIX processing cycles with a nominal column size of 450 gallons of unground CST (900 gallons unground CST total). The maximum floor temperatures anticipated for cylindrical CST mounds are compared in Figure 28 for the case involving unground media with no floor heat transfer and the case involving ground media with floor heat transfer. The case with ground CST media and floor heat transfer is probably the most representative of $\mathrm{SCIX}$ processing conditions. For this case, mound heights of $\leq 8$ inches maintain the maximum floor temperature below the $100{ }^{\circ} \mathrm{C}$ limit.

Additional calculated results for hemispherical and cylindrical ground CST mounds of various sizes with and without floor heat transfer are provided in Table 19. The modeling results show that inclusion of floor heat transfer results in acceptable maximum floor temperatures even for the $\mathbf{4 5 0}$ gallon hemispherical mound (maximum temp. $=98$ $\left.{ }^{\circ} \mathrm{C}\right)$. Quantitative comparison of the maximum mound and tank wall temperatures for the hemispherical and cylindrical mounds are made for the same mound volume (450 
gallons) in Table 20. Comparisons of flow patterns at the vertical plane surface crossing the 450 gallon hemispherical and cylindrical ground CST mounds under the same color scale are provided in Figure 29. Comparisons of temperature distributions at the vertical plane surface crossing the 450 gallon hemispherical and cylindrical ground CST mounds under the same color scale are provided in Figure 30. Table 21 shows the quantified results for the coolability of the 4.3-kW CST mound through the tank bottom wall. The calculation results demonstrate that more than one third of the total thermal loading generated by the spent CST materials accumulated on the tank floor is dissipated through the tank bottom.

Thermal analysis was also performed for mixtures of ground CST, MST, and sludge distributed as a flat layer on the tank floor. Generation of such mixtures is considered likely during SCIX processing. The impact of additional heat sources from MST and sludge materials containing strontium, plutonium, and other elements that could potentially serve as heat sources from radiolytic decay needed to be evaluated. The basis for estimated heat loads from the MST and sludge and the assumed physical and thermal properties of the materials are provided in Section 3.0. All component materials were homogeneously mixed and distributed over the entire tank floor as a uniform layer. Five different cases were considered assuming the following volumes of each material: 6,000 gallons of ground CST, 1,000 gallons of loaded MST, and 10,000 gallons of sludge. The modeling results are summarized in Table 22. The calculation results indicate that the maximum tank wall temperatures for all the cases are lower than $50{ }^{\circ} \mathrm{C}$. Based on these results and the fact that the MST and sludge heat sources are comparable to or lower than ground CST on a volumetric basis, it is expected that the presence of these additional heat sources does not greatly impact the conclusions from this work based on ground CST alone. 


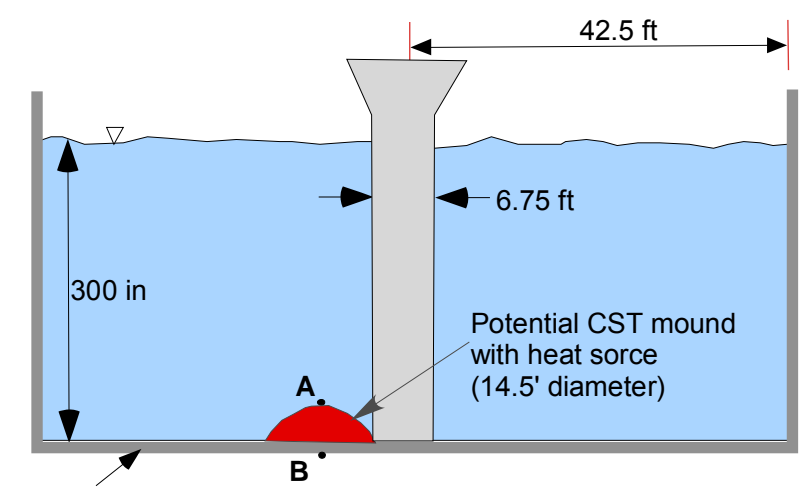

0.5 " thick SS tank wall

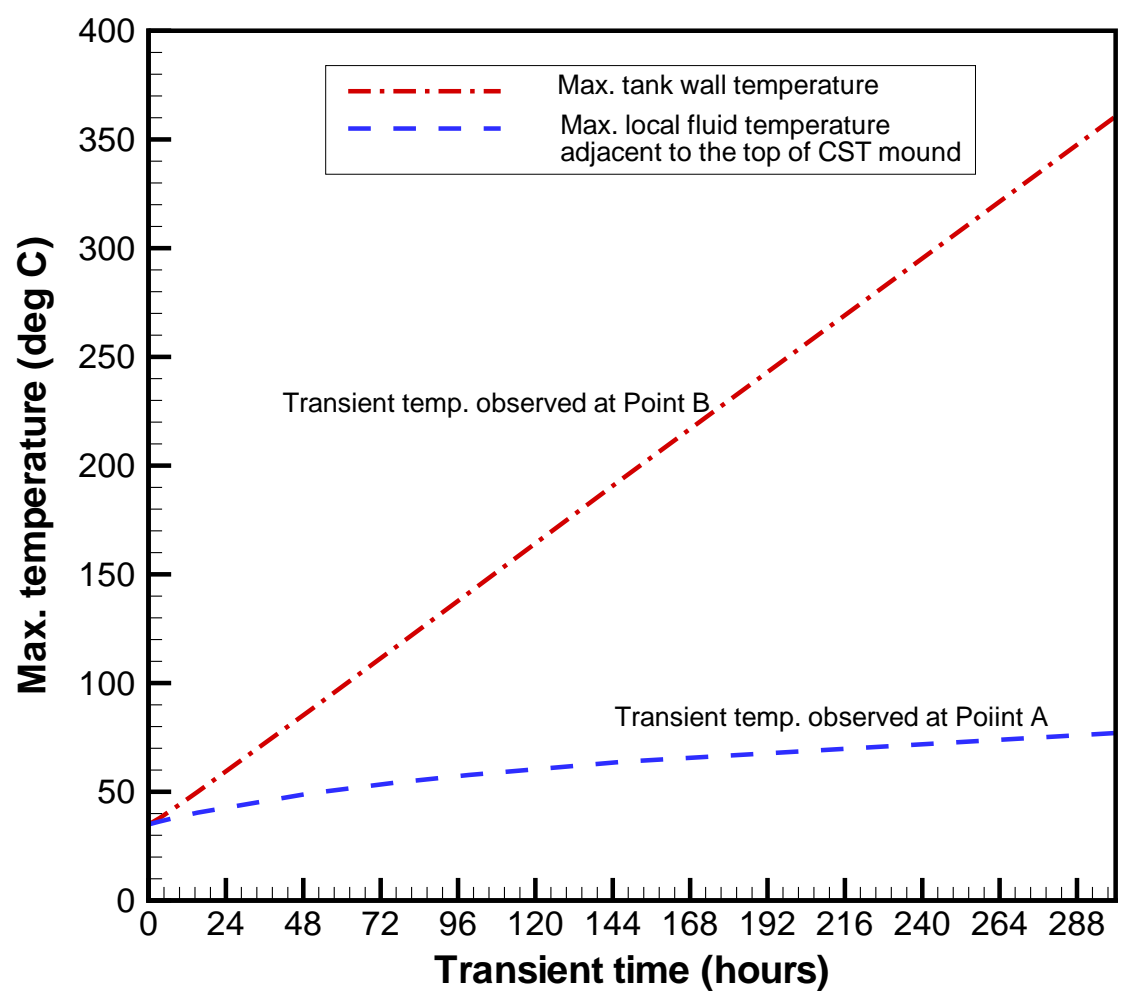

Figure 19. Transient temperatures observed at two observation points located at the top and bottom surfaces of the hemispherical mound formed under Riser $G$ of Tank $41 \mathrm{H}$ (Case 1, unground CST, adiabatic floor). 

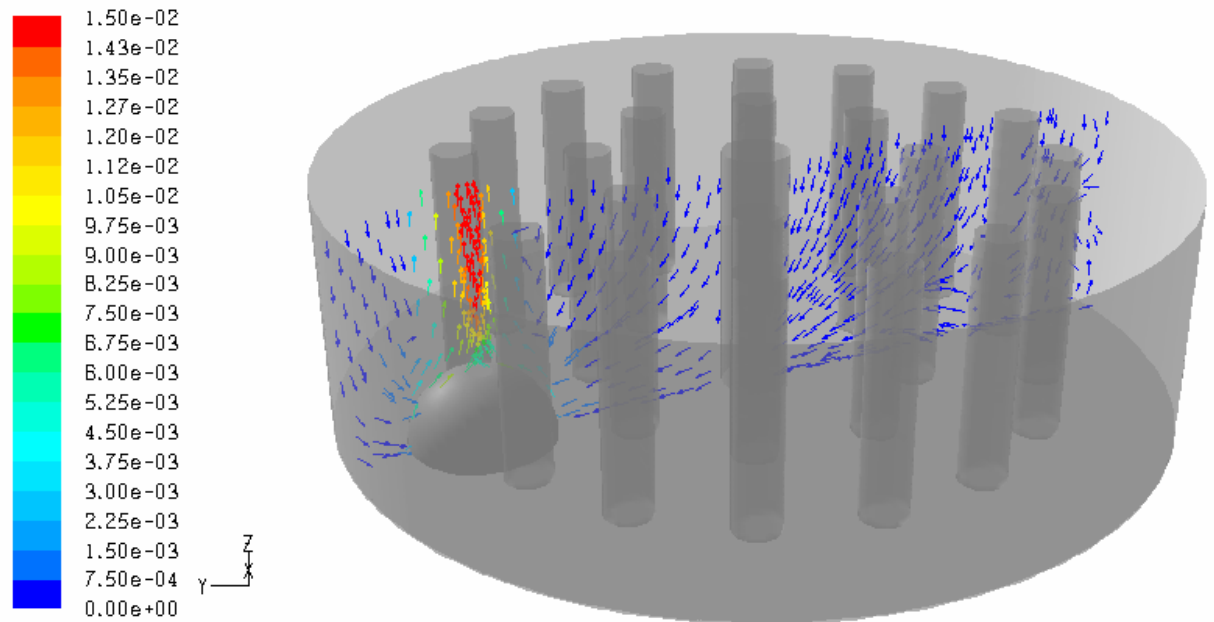

Velocity Vectors Colored By Velocity Magnitude (m/s) (Time=1.8002e+05)
FLUENT 6.3 (3d, dp, pbns, lam, unst eady)

B. $10 e+01$

$5.97 e+01$

5. $84 \mathrm{e}+01$

$5.71 e+01$

$5.5 \mathrm{Be}+01$

$5.45 \mathrm{e}+01$

$5.32 \mathrm{e}+01$

$5.19 \mathrm{e}+01$

$5.0 \mathrm{Be}+01$

$4.93 e+01$

$4.80 e+01$

$4.67 e+01$

$4.54 \mathrm{e}+01$

$4.41 e+01$

4. $2 \mathrm{Be}+01$

$4.15 e+01$

$4.02 \mathrm{e}+01$

3. $89 e+01$

$3.7 \mathrm{Be}+01$

$3.63 e+01$

$3.50 \mathrm{e}+01$
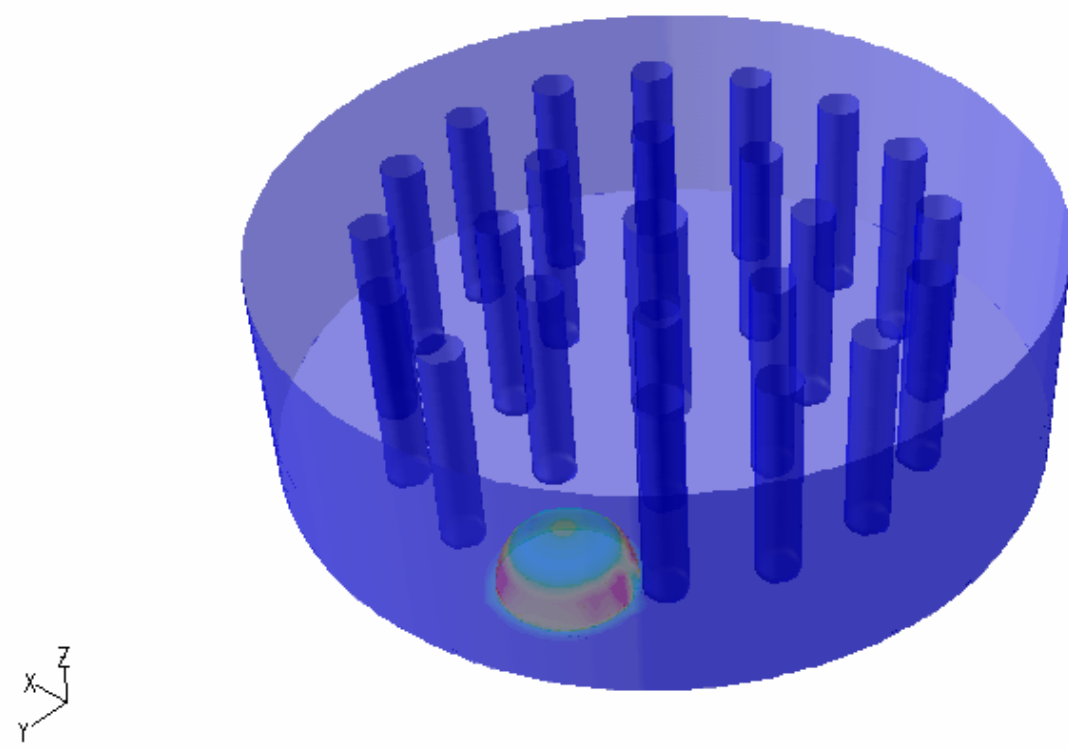

Contours of deg_c (Time=1.8002e+05)

May 12,2010

FLUENT 6.3 [3d, dp, pbns, lam, unsteady)

Figure 20. Transient snapshots for fluid flow patterns and temperature distributions at 50 hours' time duration for Case 1 (6,000 gallons unground CST, adiabatic floor). 
9. $00 e-03$

B. $55 \mathrm{e}-03$

B. $10 e-03$

$7.65 \mathrm{e}-03$

$7.20 \mathrm{e}-03$

E. $75 \mathrm{e}-03$

B. $30 e-03$

5. $85 e-03$

$5.40 \mathrm{e}-03$

$4.95 \mathrm{e}-03$

$4.50 e-03$

$4.05 e-03$

3. $\mathrm{E} 0 \mathrm{e}-03$

$3.15 \mathrm{e}-03$

2. $70 e-03$

$2.25 \mathrm{e}-03$

$1 . \mathrm{B} 0 \mathrm{e}-03$

$1.35 \mathrm{e}-03$

$9.00 e-04$

$4.50 e-04$

$0.00 e+00$

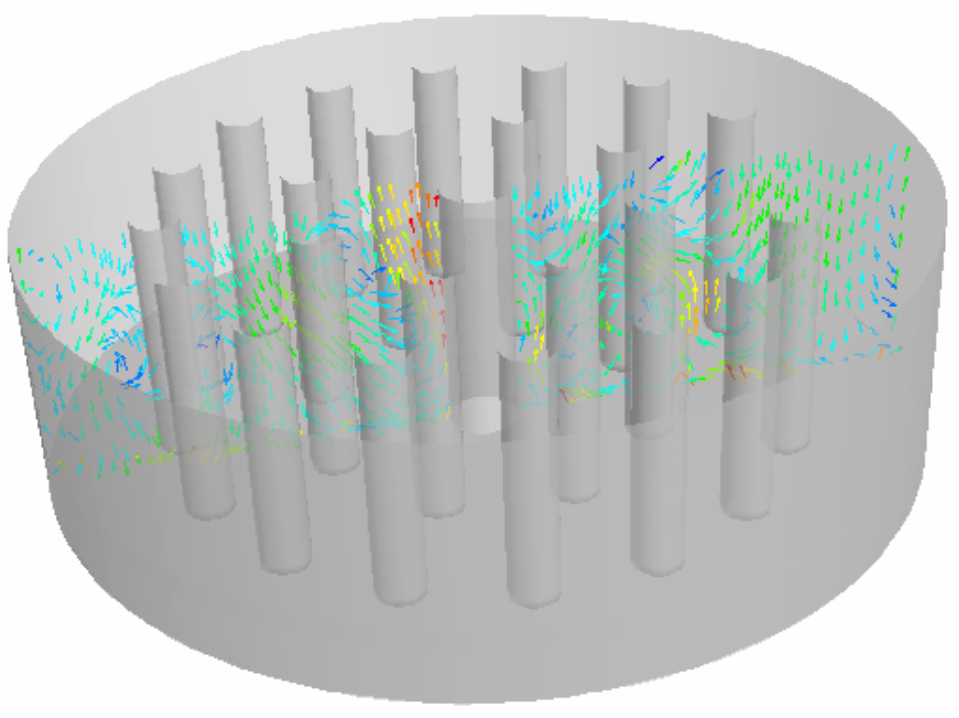

Velocity Vectors Colored By Velocity Magnitude $(\mathrm{m} / \mathrm{s})$

May 12,2010

FLUENT 6.3 (3d, dp, pbns, lam)

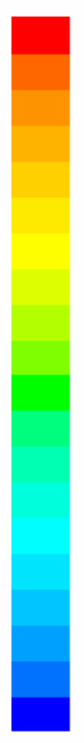

$3.99 e+01$

$3.97 e+01$

$3.94 e+01$

$3.92 e+01$

3. $89 e+01$

3. $87 e+01$

3. $84 \mathrm{e}+01$

3. $82 e+01$

$3.79 e+01$

$3.77 e+01$

$3.75 \mathrm{e}+01$

$3.72 e+01$

$3.70 e+01$

3. $67 e+01$

$3.65 e+01$

3. $62 \mathrm{e}+01$

3. $60 \mathrm{e}+01$

$3.57 e+01$

$3.55 \mathrm{e}+01$

$3.52 e+01$

$3.50 \mathrm{e}+01$

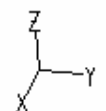

Figure 21. Steady-state flow patterns and temperature distributions for the dispersed CST layer with 1.7-in thickness (Case 2 - 6,000 gallons unground CST, adiabatic floor). 
Table 12. Summary results for the initial in-tank calculations $(6,000$ gallons unground CST, adiabatic floor)

\begin{tabular}{|c|c|c|}
\hline Parameters & Case 1 & Case 2 \\
\hline $\begin{array}{c}\text { Time duration to reach } 100^{\circ} \mathrm{C} \\
\text { max. wall temp. }\end{array}$ & 62 hours & Never reached \\
\hline $\begin{array}{c}\text { Time duration to reach } 55^{\circ} \mathrm{C} \\
\text { max. local fluid temp. }\end{array}$ & 82.5 hours & $40^{\circ} \mathrm{C}$ \\
\hline $\begin{array}{c}\text { Max. steady-state temperature } \\
\text { for SS tank wall }\end{array}$ & $1843.6^{\circ} \mathrm{C}$ & $35^{\circ} \mathrm{C}$ \\
\hline $\begin{array}{c}\text { Steady-state temperature for } \\
\text { fluid bulk temp. }\end{array}$ & $35.3^{\circ} \mathrm{C}$ & \\
\hline
\end{tabular}

Table 13. Summary results for the in-tank calculations for Case 2 with varying liquid levels (6,000 gallons unground CST, adiabatic floor)

\begin{tabular}{|c|c|c|}
\hline Parameters & 300 -in tank level & 9 -in tank level \\
\hline Total fluid volume inside tank & $1.1 \times 10^{6}$ gallons & $3.2 \times 10^{4}$ gallons \\
\hline $\begin{array}{c}\text { Max. steady-state temperature } \\
\text { for SS tank wall }\end{array}$ & $39.92^{\circ} \mathrm{C}$ & $39.89^{\circ} \mathrm{C}$ \\
\hline $\begin{array}{c}\text { Steady-state temperature for } \\
\text { max. local fluid temp. }\end{array}$ & $37.02^{\circ} \mathrm{C}$ & $37.03^{\circ} \mathrm{C}$ \\
\hline
\end{tabular}




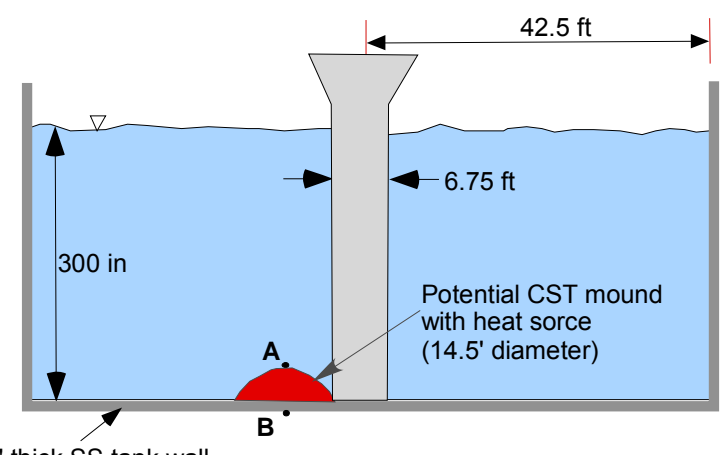

$0.5^{\prime \prime}$ thick SS tank wall

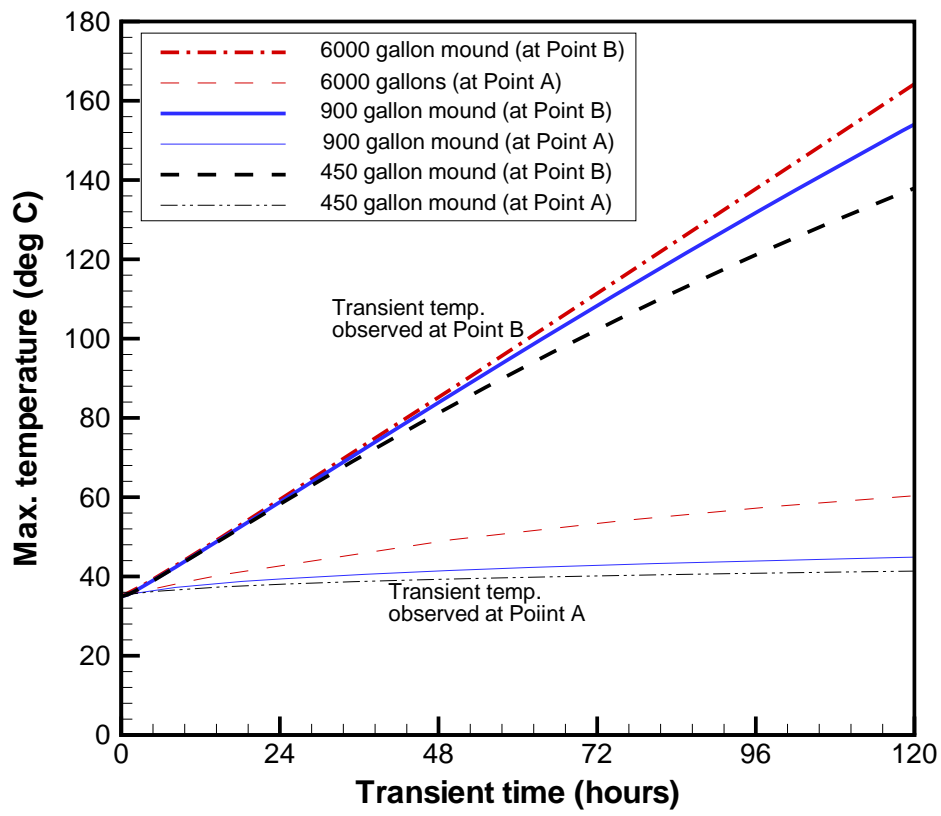

Figure 22. Transient temperatures for three different unground CST volumes at two observation points located at the top and bottom surfaces of a hemispherical mound formed under Riser $\mathrm{G}$ of Tank $41 \mathrm{H}$ (adiabatic floor). 
Table 14. In-tank calculation results for the hemispherical mound (Case 1, unground CST, adiabatic floor)

\begin{tabular}{|c|c|c|c|}
\hline $\begin{array}{c}\text { Volume of hemispherical } \\
\text { mound located at tank floor } \\
\text { (Radius) }\end{array}$ & $\begin{array}{c}\text { Time duration } \\
\text { to reach } \\
100^{\circ} \mathrm{C} \text { max. } \\
\text { wall temp }\end{array}$ & $\begin{array}{c}\text { Time duration to } \\
\text { reach } 55^{\circ} \mathrm{C} \text { max. } \\
\text { local fluid temp. }\end{array}$ & $\begin{array}{c}\text { Max. steady-state } \\
\text { temperature for SS } \\
\text { tank wall }\end{array}$ \\
\hline 6000 gallon mound $(87 \mathrm{in})$ & 62 hours & 82.5 hours & $1843.6^{\circ} \mathrm{C}$ \\
\hline 900 gallon mound (46 in) & 64 hours & $\begin{array}{c}\text { Never reached } \\
\left.\text { (max. } 54.2^{\circ} \mathrm{C}\right)\end{array}$ & $448.3^{\circ} \mathrm{C}$ \\
\hline 450 gallon mound (37 in) & 70 hours & $\begin{array}{c}\text { Never reached } \\
\left.\text { (max. } 44.7^{\circ} \mathrm{C}\right)\end{array}$ & $251.5^{\circ} \mathrm{C}$ \\
\hline
\end{tabular}

Table 15. In-tank calculation results for different unground CST mound shapes (adiabatic floor)

\begin{tabular}{|c|c|c|c|}
\hline $\begin{array}{c}\text { Mound shape located at } \\
\text { tank floor }\end{array}$ & $\begin{array}{c}\text { Time duration to } \\
\text { reach } 100^{\circ} \mathrm{C} \text { max. } \\
\text { wall temp }\end{array}$ & $\begin{array}{c}\text { Time duration to } \\
\text { reach } 55^{\circ} \mathrm{C} \text { max. } \\
\text { local fluid temp. }\end{array}$ & $\begin{array}{c}\text { Max. steady-state } \\
\text { temperature for SS } \\
\text { tank wall }\left({ }^{\circ} \mathrm{C}\right)\end{array}$ \\
\hline $\begin{array}{c}\text { Hemispherical shape } \\
\text { (37 in radius: } 450 \text { gallons) }\end{array}$ & 70 hours & $\begin{array}{c}\text { Never reached } \\
\left.\text { (max. } 44.7^{\circ} \mathrm{C}\right)\end{array}$ & 251.5 \\
\hline $\begin{array}{c}\text { Cylindrical shape } \\
(24 \text { in high: } 450 \text { gallons) }\end{array}$ & 70 hours & $\begin{array}{c}75 \text { hours } \\
\left(\text { max. } 81.9^{\circ} \mathrm{C}\right)\end{array}$ & 244.6 \\
\hline $\begin{array}{c}\text { Cylindrical shape } \\
\text { (12 in high: } 450 \text { gallons })\end{array}$ & 71 hours & $\begin{array}{c}140 \text { hours } \\
\left(\max .60 .5^{\circ} \mathrm{C}\right)\end{array}$ & 170.3 \\
\hline $\begin{array}{c}\text { Cylindrical shape } \\
(6 \text { in high: } 450 \text { gallons })\end{array}$ & -- & $\begin{array}{c}\text { Never reached } \\
\left.\text { (max. } 45.9^{\circ} \mathrm{C}\right)\end{array}$ & 81.2 \\
\hline
\end{tabular}




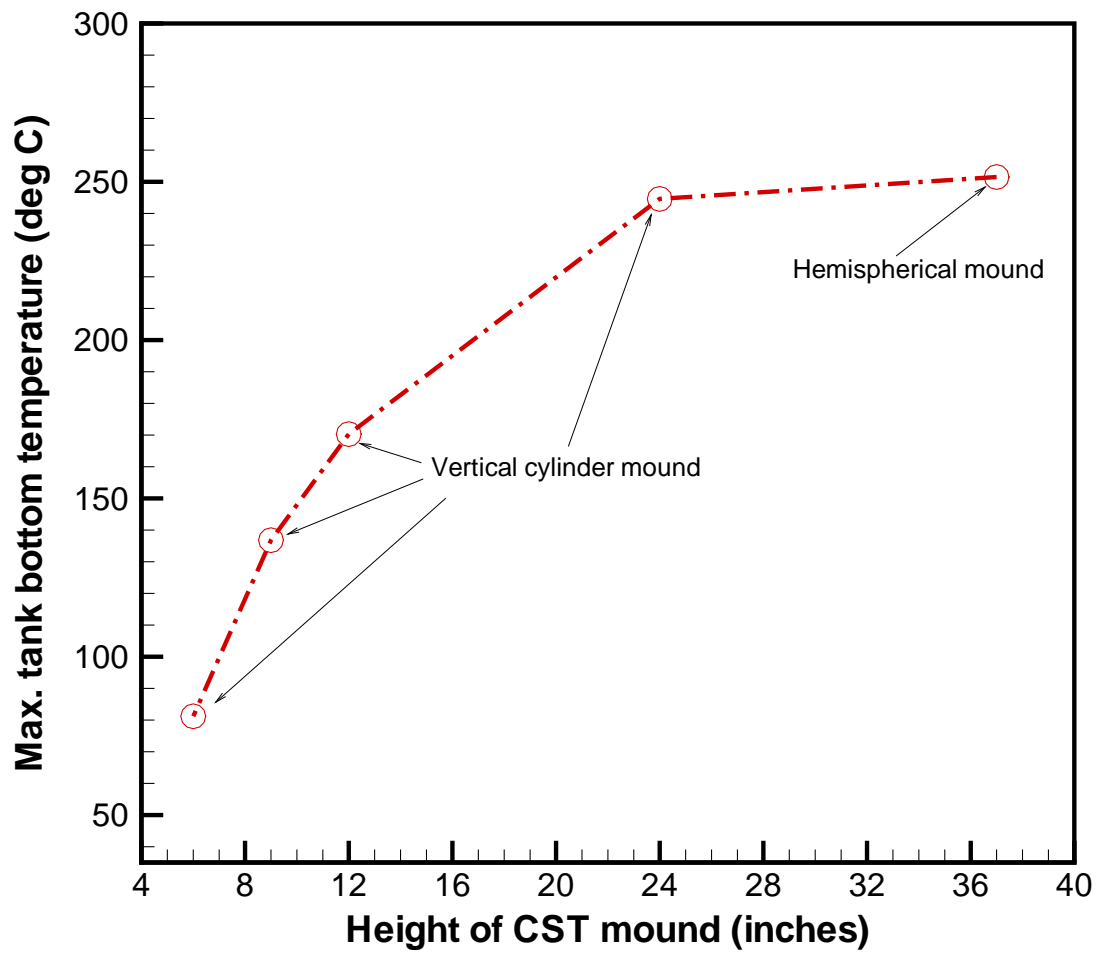

Figure 23. Max. temperatures at the tank bottom surface of the unground CST mound formed under Riser $\mathrm{G}$ of Tank $41 \mathrm{H}$ for different CST mound heights (adiabatic floor). 
B. $12 e+01$

7. $\mathrm{Bge}+01$

$7.65 e+01$

$7.42 \mathrm{e}+01$

$7.19 e+01$

B. $9 \mathrm{Be}+01$

B. $73 e+01$

B. $50 \mathrm{e}+01$

B. $27 e+01$

B. $04 e+01$

$5 . \mathrm{Bl} \mathrm{e}+01$

5. $5 \mathrm{Be}+01$

$5.35 e+01$

$5.12 \mathrm{e}+01$

4. $\mathrm{BBe}+01$

$4.65 e+01$

$4.4 \mathrm{Ze}+01$

$4.19 e+01$

3. $9 \mathrm{Ee}+01$

$3.73 e+01$

$3.50 e+01$

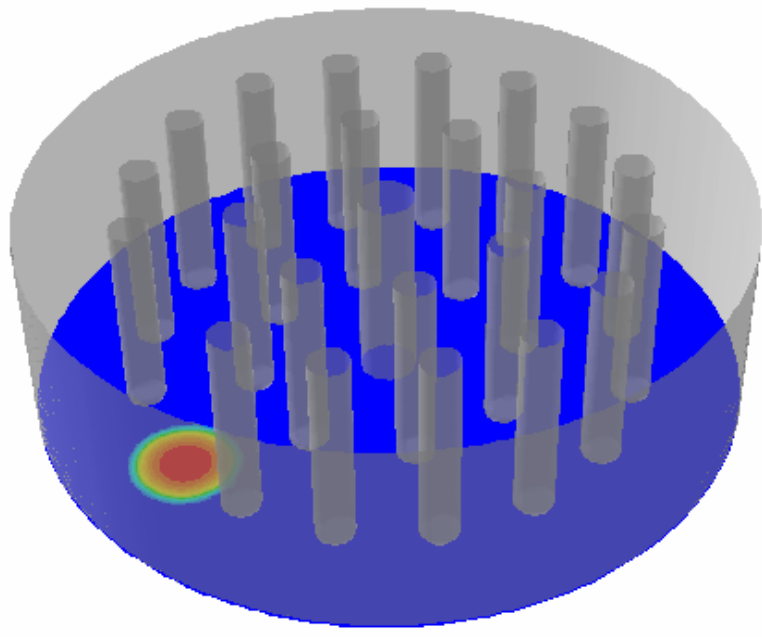

Contours of deg_c

Juก 07, 2010

FLUENT 6.3 [3d, dp, pbns, lam)

Figure 24. Tank bottom temperatures for 450 gallon cylindrical unground CST mound with 6 -in height located under the Riser G (adiabatic floor).
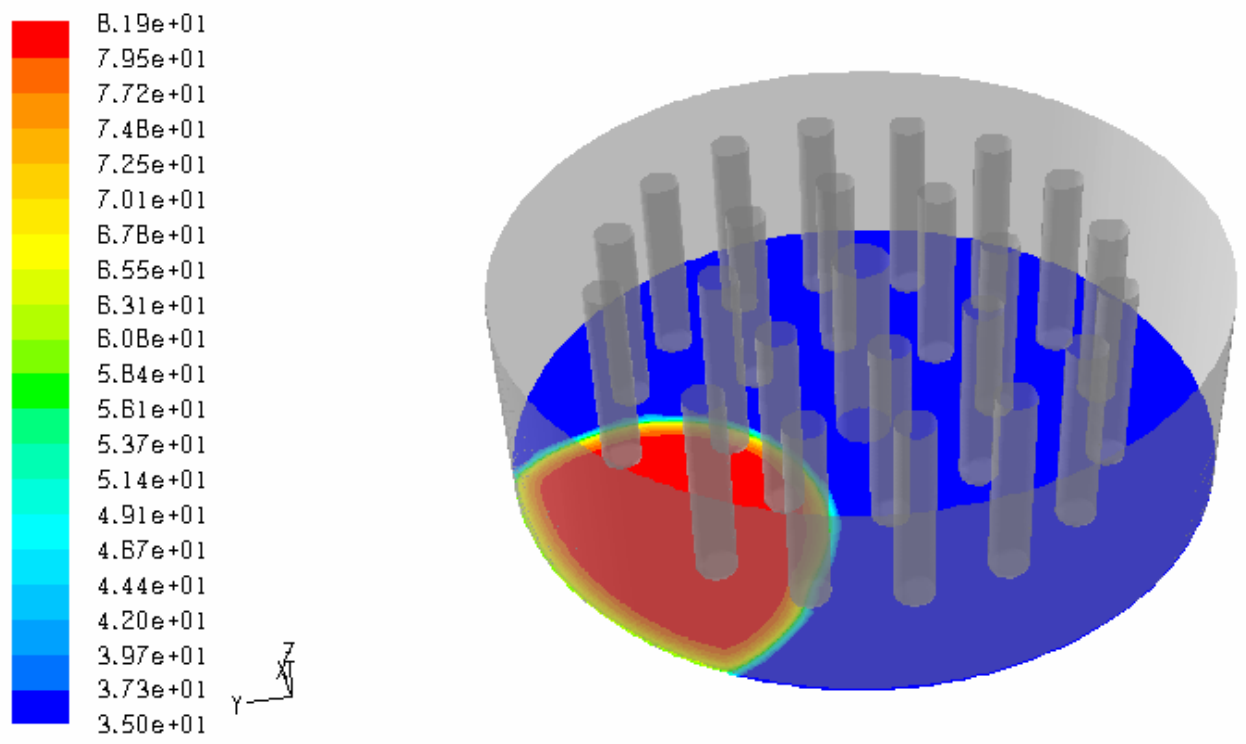

Contours of deg_c

Jun 07,2010

FLUENT 6.3 (3d, dp, pbns, lam)

Figure 25. Tank bottom temperatures for 4200 gallon cylindrical unground CST mound with 6 -in height located under the Riser G (adiabatic floor). 
Table 16. In-tank calculation results for 6-in high cylindrical mounds with different unground CST volumes (adiabatic floor)

\begin{tabular}{|c|c|c|c|}
\hline $\begin{array}{c}\text { Volume of the CST mound } \\
\text { located at tank floor }\end{array}$ & $\begin{array}{c}\text { Ratio of cooling } \\
\text { surface area to } \\
\text { volume }\end{array}$ & $\begin{array}{c}\text { Max. steady-state } \\
\text { local fluid temp. } \\
\text { at top of CST } \\
\text { mound }\end{array}$ & $\begin{array}{c}\text { Max. steady-state } \\
\text { temperature for SS } \\
\text { tank wall }\end{array}$ \\
\hline $\begin{array}{c}4200 \text { gallon mound } \\
(6 \text { in height })\end{array}$ & 7.0 & $46.0^{\circ} \mathrm{C}$ & $81.9^{\circ} \mathrm{C}$ \\
\hline $\begin{array}{c}450 \text { gallon mound } \\
(6 \text { in height })\end{array}$ & 7.6 & $45.9^{\circ} \mathrm{C}$ & $81.2^{\circ} \mathrm{C}$ \\
\hline
\end{tabular}


Table 17. Quantitative comparison of maximum tank bottom surface temperatures with and without heat transfer for different cylindrical, unground CST mound heights

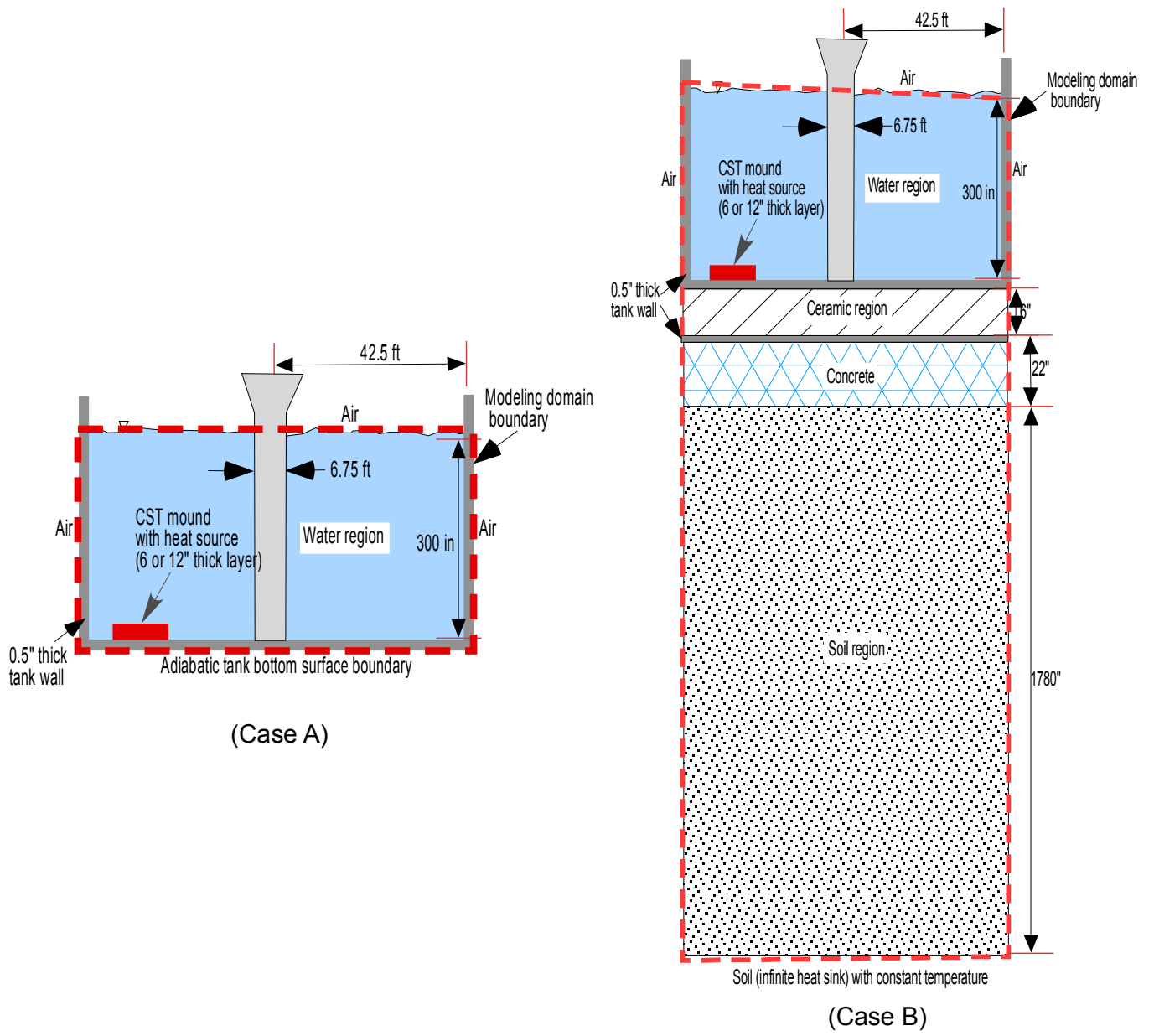

\begin{tabular}{|c|c|c|c|}
\hline $\begin{array}{c}\text { Volume of the } \\
\text { CST mound } \\
\text { located at tank } \\
\text { floor }\end{array}$ & $\begin{array}{c}\text { CST loading } \\
(257 \mathrm{Ci} / \text { liter })^{*}\end{array}$ & $\begin{array}{c}\text { No heat transfer allowed at } \\
\text { tank bottom } \\
\text { (Case A: Baseline model) }\end{array}$ & $\begin{array}{c}\text { Heat transfer } \\
\text { allowed at tank } \\
\text { bottom (Case B) }\end{array}$ \\
\hline $\begin{array}{c}\text { 12-in high } \\
\text { cylindrical (900 } \\
\text { gallons) }\end{array}$ & $100 \%$ & $170.3^{\circ} \mathrm{C}$ & $81.2^{\circ} \mathrm{C}$ \\
\hline $\begin{array}{c}\text { 9-in high } \\
\text { cylindrical (675 } \\
\text { gallons) }\end{array}$ & $100 \%$ & $136.8^{\circ} \mathrm{C}$ & $68.8^{\circ} \mathrm{C}$ \\
\hline $\begin{array}{c}\text { 6-in high } \\
\text { cylindrical (450 } \\
\text { gallons) }\end{array}$ & $100 \%$ & $81.2^{\circ} \mathrm{C}$ & $54.8^{\circ} \mathrm{C}$ \\
\hline
\end{tabular}

* based on unground CST particulate 


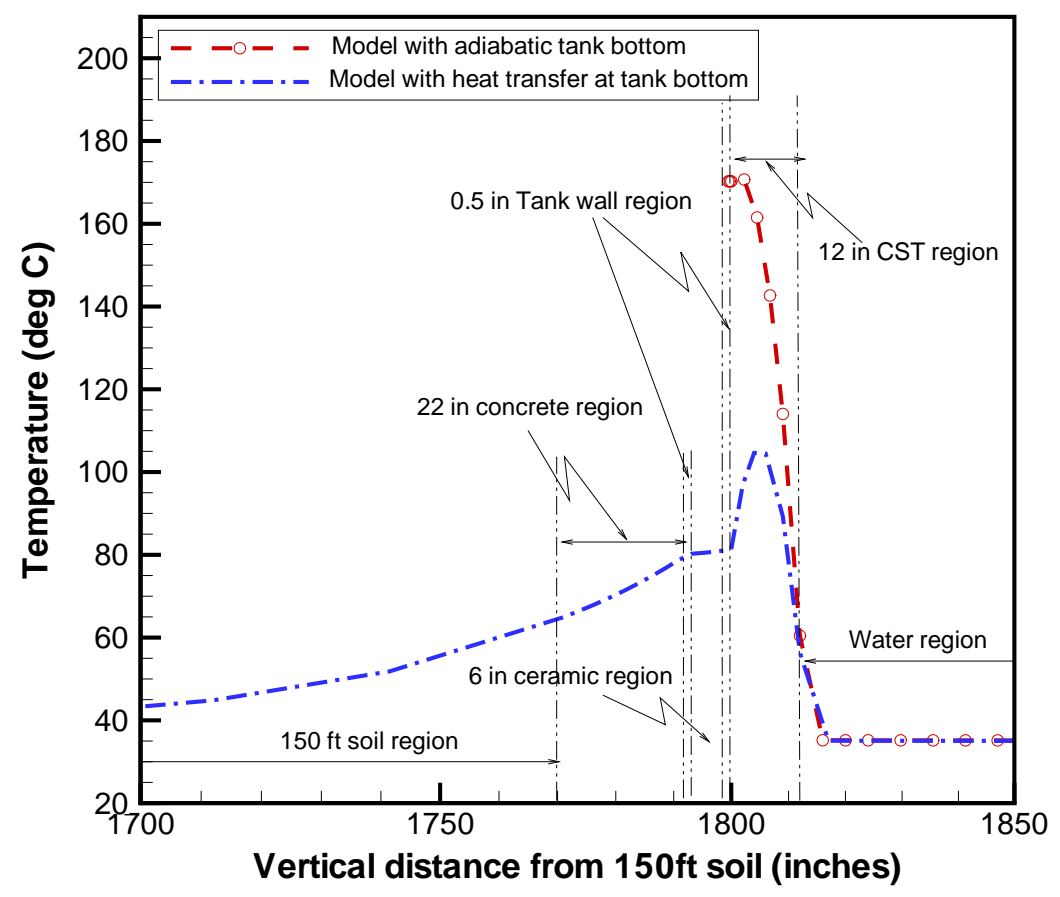

Figure 26. Comparison of temperatures between the models with and without heat transfer through the tank bottom for 12-in cylindrical pancake mound (unground CST)

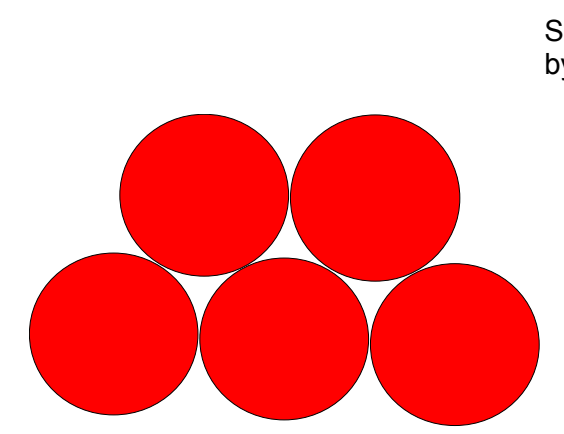

(CST packing with uniform sizes)
Small particles reduces the porosity by filling the voids among the large particles.

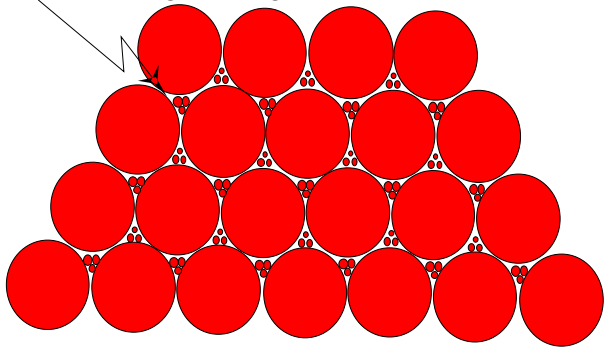

(Ground CST packing with non-uniform sizes)

Figure 27. Uniform and non-uniform ground CST packings $[17,18]$ 
Table 18. Quantitative comparison of maximum tank bottom surface temperatures with and without floor heat transfer for cylindrical mounds with original and ground CST particulates

\begin{tabular}{|c|c|c|c|c|c|}
\hline \multirow{2}{*}{$\begin{array}{l}\text { Volume of the CST } \\
\text { mound located at } \\
\text { tank floor }\end{array}$} & \multirow{2}{*}{$\begin{array}{l}100 \% \text { CST } \\
\text { loading }\end{array}$} & \multicolumn{2}{|c|}{$\begin{array}{c}\text { No heat transfer allowed at } \\
\text { tank bottom } \\
\text { (Case A: Baseline model) }\end{array}$} & \multicolumn{2}{|c|}{$\begin{array}{l}\text { Heat transfer allowed at tank } \\
\text { bottom (Case B) }\end{array}$} \\
\hline & & $\begin{array}{l}\text { Max. tank wall } \\
\text { surface temp. }\end{array}$ & $\begin{array}{l}\text { Max. mound } \\
\text { temp }\end{array}$ & $\begin{array}{l}\text { Max. tank wall } \\
\text { surface temp. }\end{array}$ & $\begin{array}{l}\text { Max. mound } \\
\text { temp }\end{array}$ \\
\hline \multirow{2}{*}{$\begin{array}{c}\text { 9-in high pan cake } \\
\text { (675 gal) }\end{array}$} & Original CST & $136.8^{\circ} \mathrm{C}$ & $136.8^{\circ} \mathrm{C}$ & $68.8^{\circ} \mathrm{C}$ & $80.6^{\circ} \mathrm{C}$ \\
\hline & Ground CST* & $268.6^{\circ} \mathrm{C}$ & $268.6{ }^{\circ} \mathrm{C}$ & $104.3^{\circ} \mathrm{C}$ & $135.6^{\circ} \mathrm{C}$ \\
\hline \multirow{2}{*}{$\begin{array}{l}\text { 6-in high pan cake } \\
\text { (450 gal) }\end{array}$} & Original CST & $81.2^{\circ} \mathrm{C}$ & $81.2^{\circ} \mathrm{C}$ & $54.8^{\circ} \mathrm{C}$ & $58.7^{\circ} \mathrm{C}$ \\
\hline & Ground $\mathrm{CST}^{*}$ & $141.9^{\circ} \mathrm{C}$ & $141.9^{\circ} \mathrm{C}$ & $76.5^{\circ} \mathrm{C}$ & $86.8^{\circ} \mathrm{C}$ \\
\hline
\end{tabular}

*based on $50 \%$-reduced void volume after the completion of the CST grinding process; 450 gallons of ground CST contains twice the heat load of 450 gallons of original CST material and is equivalent to two processing cycles assuming a 450 gallon column

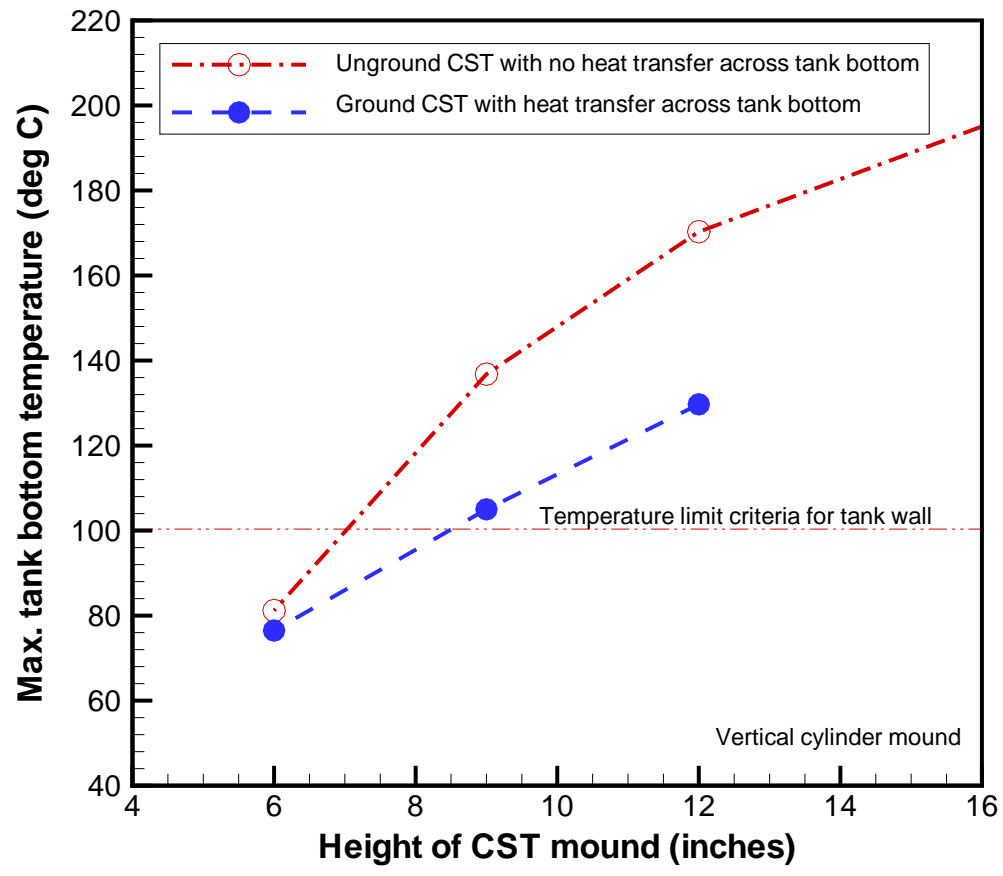

Figure 28. Maximum temperatures at the tank bottom surface of ground and unground cylindrical CST mounds formed under Riser $\mathrm{G}$ of Tank $41 \mathrm{H}$ with and without heat transfer through the tank bottom 
Table 19. Quantitative comparison of maximum tank bottom surface temperatures with and without heat transfer for different ground, cylindrical CST mound heights

\begin{tabular}{|c|c|c|c|c|}
\hline \multicolumn{2}{|c|}{$\begin{array}{c}\text { Shape and volume of the CST } \\
\text { mound located at tank floor }\end{array}$} & $\begin{array}{c}\text { 100\% CST } \\
\text { loading }\end{array}$ & $\begin{array}{c}\text { No heat transfer allowed } \\
\text { at tank bottom } \\
\text { (Case A: Baseline model) }\end{array}$ & $\begin{array}{c}\text { Heat transfer } \\
\text { allowed at tank } \\
\text { bottom } \\
\text { (Case B) }\end{array}$ \\
\cline { 1 - 2 } Mound shape & Volume & Ground CST* & $141.9^{\circ} \mathrm{C}$ & $76.5^{\circ} \mathrm{C}$ \\
\hline $\begin{array}{c}\text { 6-in high } \\
\text { cylinder }\end{array}$ & 450 gal & Ground CST* & $268.6^{\circ} \mathrm{C}$ & $104.3^{\circ} \mathrm{C}$ \\
\hline $\begin{array}{c}\text { 9-in high } \\
\text { cylinder }\end{array}$ & 675 gal & Ground CST* & Much higher than $100^{\circ} \mathrm{C}$ & $129.7^{\circ} \mathrm{C}$ \\
\hline $\begin{array}{c}12 \text {-in high } \\
\text { cylinder }\end{array}$ & 900 gal & Ground CST* & Much higher than $100^{\circ} \mathrm{C}$ & $97.8^{\circ} \mathrm{C}$ \\
\hline $\begin{array}{c}\text { Hemisphere } \\
\text { (37-in radius) }\end{array}$ & 450 gal. & & \\
\hline
\end{tabular}

* based on 50\%-reduced void volume after the completion of the CST grinding process; 450 gallons of ground CST contains two times heat load of 450 gallons of the original CST material

Table 20. Quantitative comparison of maximum tank wall temperatures for the hemispherical and cylindrical mounds for 450 gallon mounds of ground and unground CST

\begin{tabular}{|c|c|c|c|c|c|}
\hline \multirow{2}{*}{$\begin{array}{c}\text { Volume of the } \\
\text { CST mound } \\
\text { located at tank } \\
\text { floor }\end{array}$} & $\begin{array}{c}100 \% \mathrm{CST} \\
\text { loading }\end{array}$ & \multicolumn{2}{|c|}{$\begin{array}{c}\text { No heat transfer allowed at } \\
\text { tank bottom } \\
\text { (Case A: Baseline model) }\end{array}$} & \multicolumn{2}{|c|}{$\begin{array}{c}\text { Heat transfer allowed at tank } \\
\text { bottom (Case B) }\end{array}$} \\
\cline { 2 - 6 } & $\begin{array}{c}\text { Max. mound } \\
\text { temp. }\end{array}$ & $\begin{array}{c}\text { Max. tank } \\
\text { bottom temp. }\end{array}$ & $\begin{array}{c}\text { Max. mound } \\
\text { temp. }\end{array}$ & $\begin{array}{c}\text { Max. tank bottom } \\
\text { temp. }\end{array}$ \\
\hline $\begin{array}{c}\text { Hemispherical } \\
\text { shape (37-in } \\
\text { radius: } 450 \text { gal.) }\end{array}$ & Original CST & $328.9^{\circ} \mathrm{C}$ & $251.5^{\circ} \mathrm{C}$ & $258.9^{\circ} \mathrm{C}$ & $66.1^{\circ} \mathrm{C}$ \\
\cline { 2 - 6 } & Ground CST* & $725.1^{\circ} \mathrm{C}$ & $506.7^{\circ} \mathrm{C}$ & $574.1^{\circ} \mathrm{C}$ & $97.8^{\circ} \mathrm{C}$ \\
\hline $\begin{array}{c}6 \text {-in high } \\
\text { Cylindrical } \\
\text { shape (450 gal) }\end{array}$ & Original CST & $81.2^{\circ} \mathrm{C}$ & $81.2^{\circ} \mathrm{C}$ & $58.7{ }^{\circ} \mathrm{C}$ & $54.8^{\circ} \mathrm{C}$ \\
\cline { 2 - 6 } & Ground CST* & $141.9^{\circ} \mathrm{C}$ & $141.9^{\circ} \mathrm{C}$ & $86.8{ }^{\circ} \mathrm{C}$ & $76.5^{\circ} \mathrm{C}$ \\
\hline
\end{tabular}

* based on 50\%-reduced void volume after the completion of the CST grinding process; 450 gallons of ground CST contains two times heat load of 450 gallons of the original CST material 


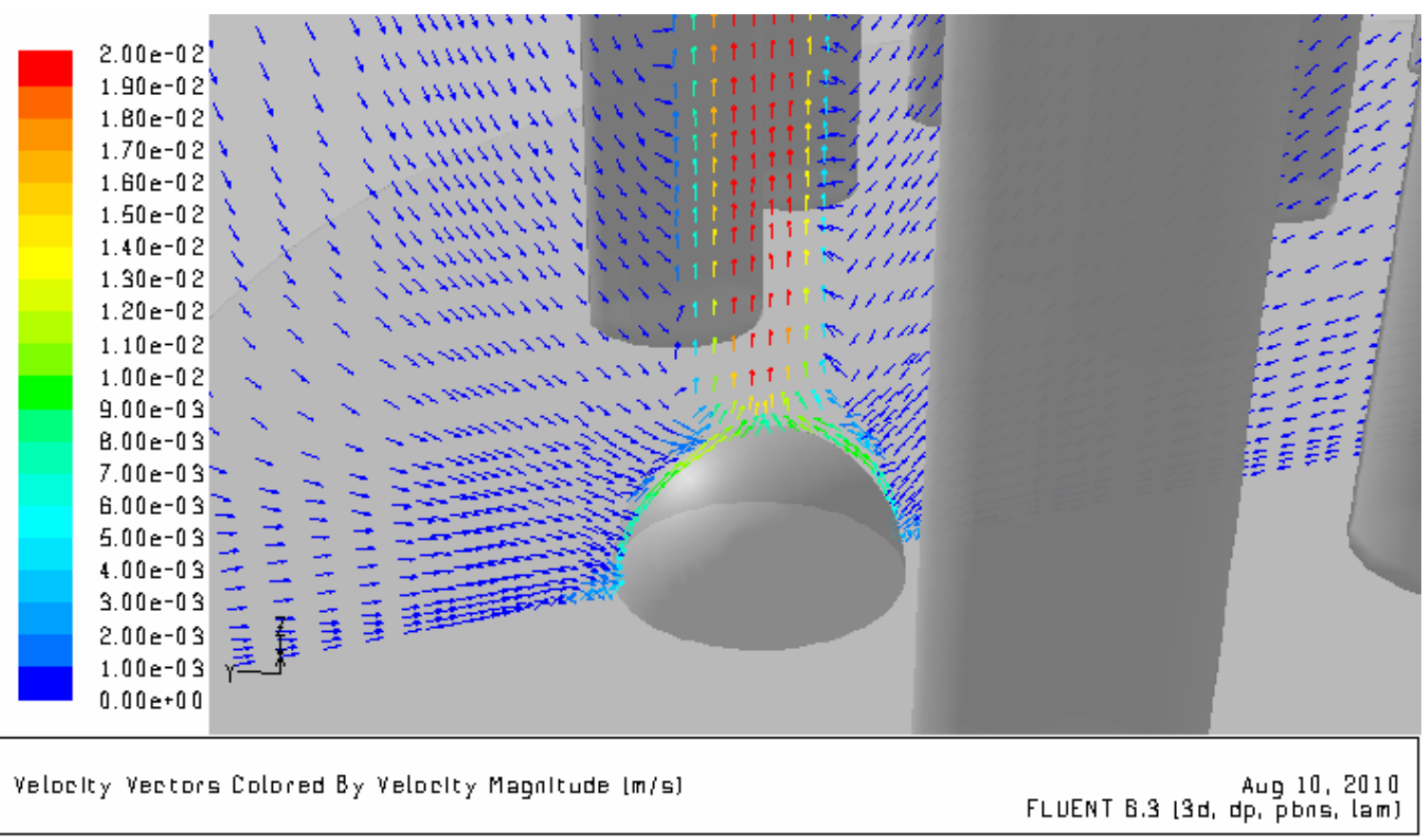

(Hemispherical CST mound of 37-inch radius corresponding to 450 gallons)

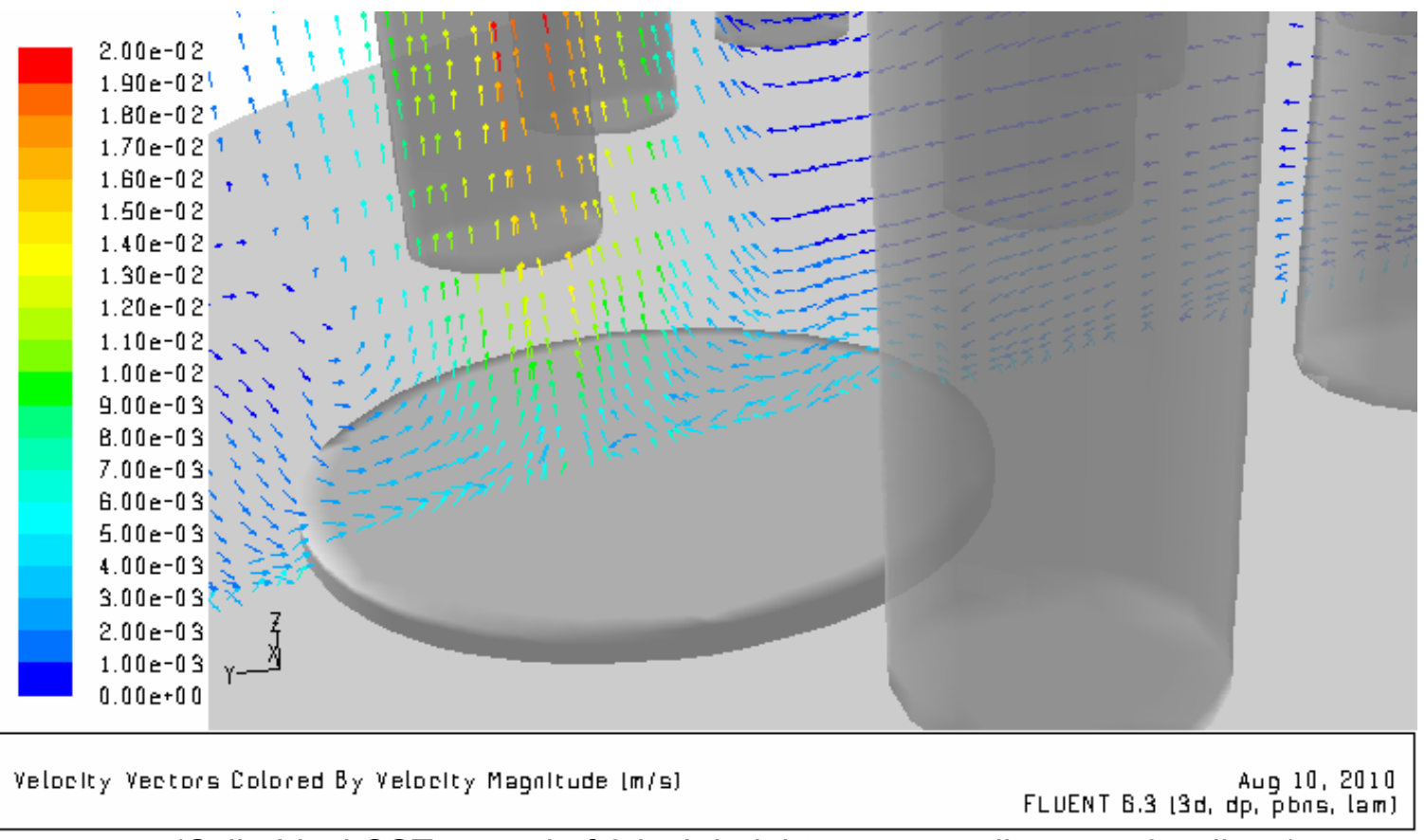

(Cylindrical CST mound of 6-inch height corresponding to 450 gallons)

Figure 29. Comparison of fluid flow patterns at the vertical plane surface crossing the hemispherical and cylindrical ground CST mounds under the same color scale 
SRNL-STI-2010-00570

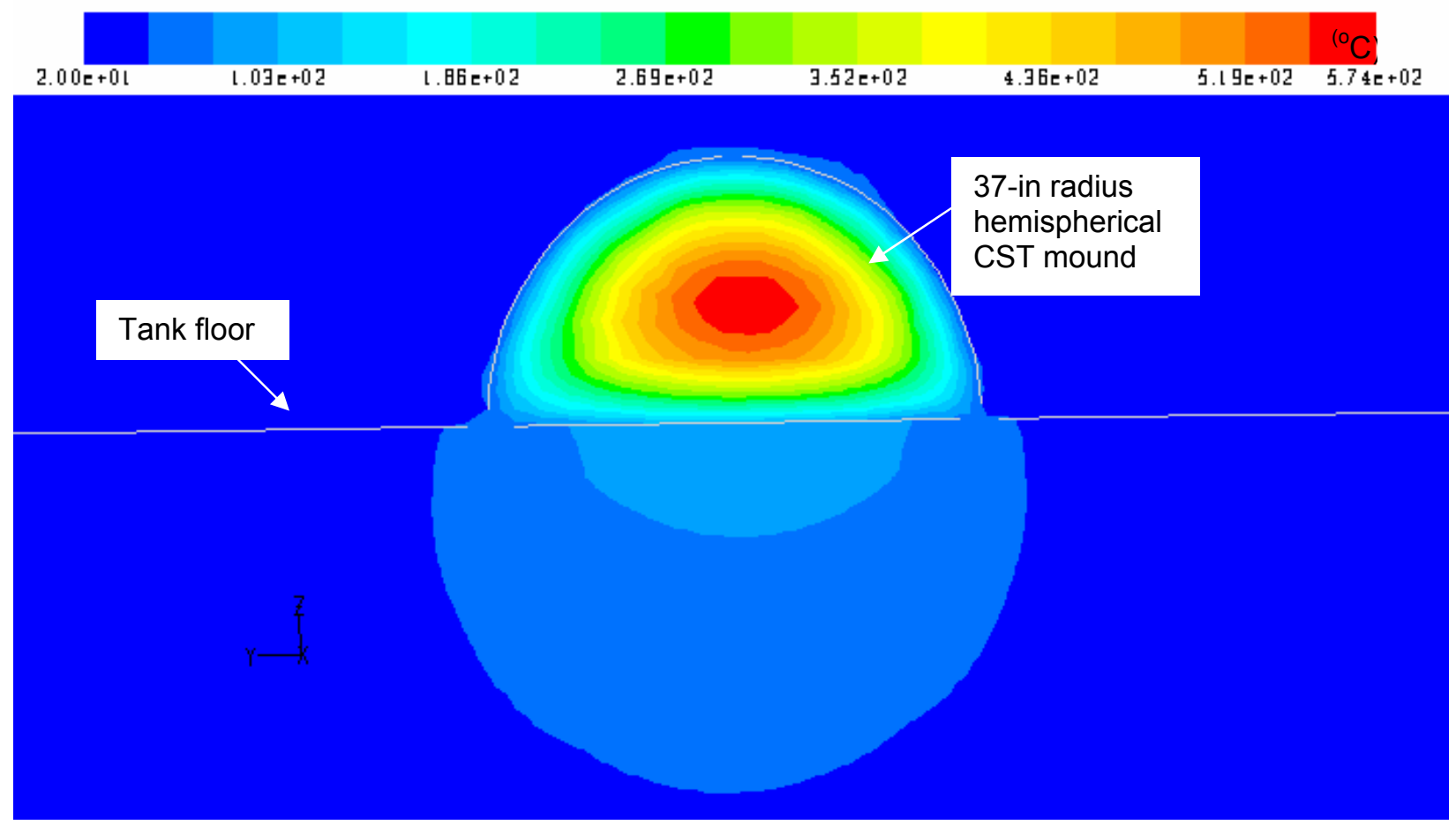

(Hemispherical CST mound of 37-inch radius corresponding to 450 gallons)

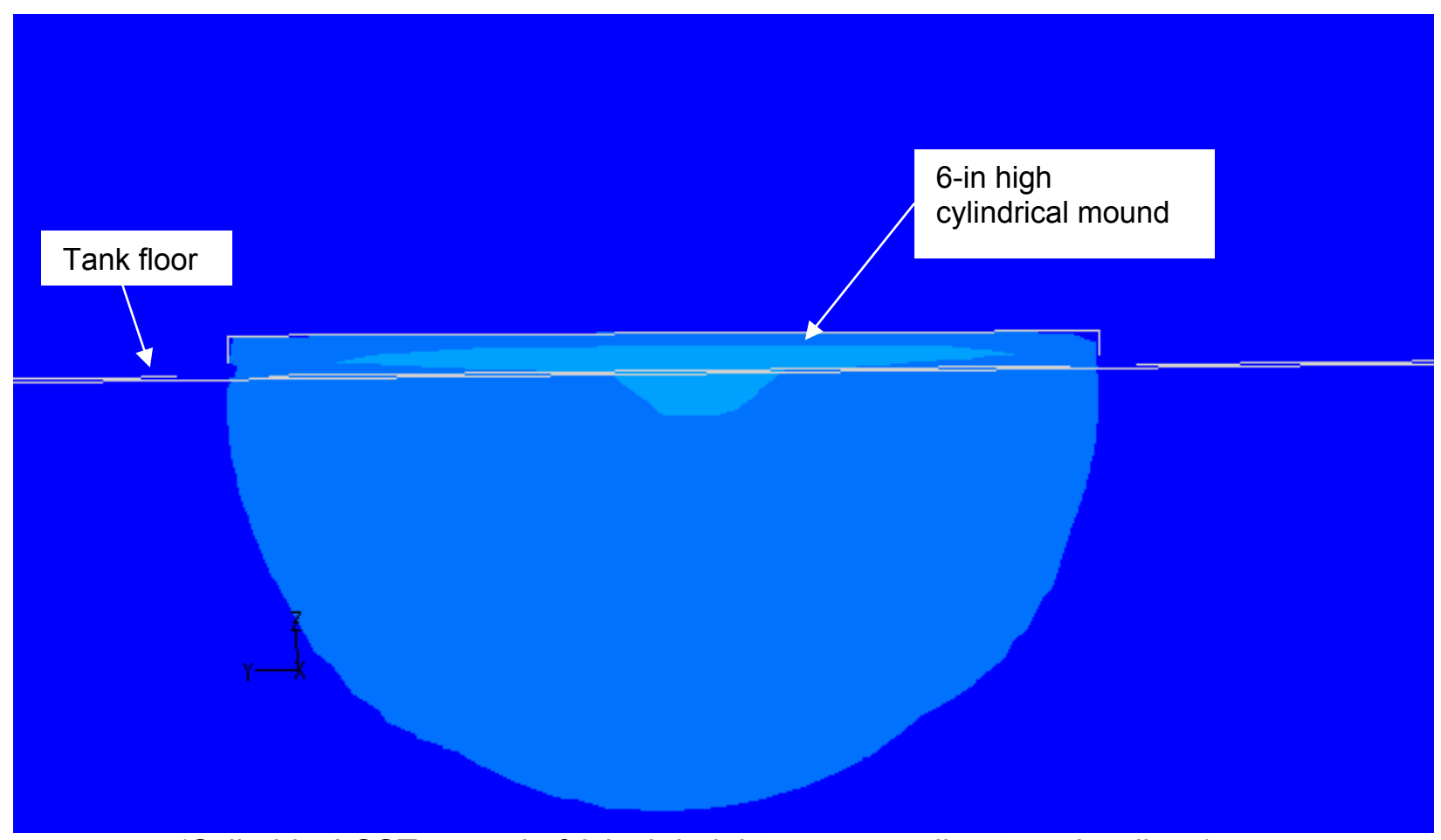

(Cylindrical CST mound of 6-inch height corresponding to 450 gallons)

Figure 30. Comparison of temperature distributions at the vertical plane crossing the hemispherical and cylindrical ground CST mounds under the same color scale 
Table 21. Heat distribution from the ground CST mound

\begin{tabular}{|c|c|c|c|}
\hline $\begin{array}{c}450 \text { gallon CST } \\
\text { mound }\end{array}$ & $\begin{array}{c}\text { Total ground CST } \\
\text { heat load (watts) }\end{array}$ & $\begin{array}{c}\text { Cooling by water } \\
\text { (watts) }\end{array}$ & $\begin{array}{c}\text { Cooling by soil } \\
\text { region (watts) }\end{array}$ \\
\hline $\begin{array}{c}\text { Hemispherical } \\
\text { shape }\end{array}$ & 4338 & $2929(68 \%)$ & $1409(32 \%)$ \\
\hline $\begin{array}{c}6 \text {-in high cylindrical } \\
\text { shape }\end{array}$ & 4338 & $2631(61 \%)$ & $1707(39 \%)$ \\
\hline
\end{tabular}

Table 22. In tank results for the flat layer configuration consisting of mixtures of ground CST, unground MST, and sludge

\begin{tabular}{|c|c|c|c|c|}
\hline \multicolumn{2}{|c|}{$\begin{array}{c}\text { Layer constituent and volume } \\
\text { (gallons) }\end{array}$} & $\begin{array}{c}\text { Power } \\
\text { density } \\
\left(\mathrm{W} / \mathrm{m}^{3}\right)\end{array}$ & $\begin{array}{c}\text { Volume- } \\
\text { averaged power } \\
\text { density }\left(\mathrm{W} / \mathrm{m}^{3}\right)\end{array}$ & $\begin{array}{c}\text { Max. tank } \\
\text { wall temp. } \\
\left({ }^{\circ} \mathrm{C}\right)\end{array}$ \\
\hline \multicolumn{2}{|c|}{ Ground CST: 6000 gal. } & $\begin{array}{c}\text { CST: } \\
2970.0\end{array}$ & 2970.0 & 47.7 \\
\hline Ground CST: 6,000 & $\begin{array}{c}\text { Sludge: } \\
10,000\end{array}$ & $\begin{array}{c}\text { CST: } 2970.0, \\
\text { Sludge:334.0 }\end{array}$ & 1322.5 & 39.6 \\
\hline Ground CST: 6,000 & MST: 1,000 & $\begin{array}{c}\text { CST: } 2970, \\
\text { MST: } 1010.7\end{array}$ & 2834.5 & 47.6 \\
\hline Ground CST: 6,000 & MST: 1,000 & $\begin{array}{c}\text { CST: } 2970, \\
\text { MST: } 2021.4\end{array}$ & 3123.3 & 39.8 \\
\hline Ground CST: & Sludge: \\
10,000 & MST: 1,000 & $\begin{array}{l}\text { CST: } 2970.0, \\
\text { Sludge: } 334.0 \\
\text { MST: } 1010.7\end{array}$ & 1363.6 & \\
\hline
\end{tabular}

\subsection{CONCLUSIONS}

The main results are summarized as follows:

- With $5 \mathrm{gpm}$ supernate flow through the column and without active engineered cooling the maximum column temperature should be below $40^{\circ} \mathrm{C}$.

- For a CST column filled with stagnant supernate and with active engineered cooling and $35{ }^{\circ} \mathrm{C}$ ambient external air, the peak temperature for the fully-loaded wet column is about $65{ }^{\circ} \mathrm{C}$, which is well below the supernate boiling point. This maximum temperature is marginally acceptable with regard to the chemical and physical stability of the CST media.

- The calculated peak temperature of the naturally-cooled (no active cooling) column filled with stagnant supernate is about $160{ }^{\circ} \mathrm{C}$. This temperature would not be observed since these conditions would promote supernate boiling at around $130{ }^{\circ} \mathrm{C}$. 
The column is expected to reach the supernate boiling point within 6 days under these conditions.

- For the air-filled column case with active engineered cooling, the maximum temperature is expected to be below $140^{\circ} \mathrm{C}$.

- For the air-filled column case without active engineered cooling, the maximum temperature is expected to be below $290^{\circ} \mathrm{C}$.

- The column temperature exceeds $100{ }^{\circ} \mathrm{C}$ within 24 hours for the air-filled column with or without active engineered cooling.

- Active air flow through the dry column at 80 SCFM effectively maintains the maximum column temperature below $100^{\circ} \mathrm{C}$.

- The impact of the central cooling tube is very large under wet and dry column conditions since the cooling region is located at the hottest spot in the column.

- In-tank CST modeling results revealed that a hemispherical shape is the worst case mound geometry and leads to the highest tank floor temperatures. In contrast, even large volumes of CST distributed in a flat layer do not result in significant floor heating.

- Evaluations of cylindrical mounds with high aspect ratios revealed that the mound height (rather than the width or volume) is the primary factor influencing the maximum floor temperature, indicating that for this geometry the heat transfer pathway is primarily vertical.

- For cylindrical mounds of ground CST with heights of $\leq 8$ inches, the maximum floor temperature is maintained below the $100{ }^{\circ} \mathrm{C}$ floor temperature limit. The results indicate that regardless of the total CST volume, floor temperature limits will not be exceeded as long as no piles of CST are present with a height exceeding 8 inches. Based on these results in-tank mixing of the spent CST is required.

- For ground CST distributed in an ideal hemispherical shape, 450 gallons of material results in a maximum tank bottom temperature just below $100{ }^{\circ} \mathrm{C}$. This volume of ground material is assumed to be equivalent to two SCIX processing cycles using a 450 gallon (unground basis) ion exchange bed.

- 6,000 gallons of ground CST distributed as a flat layer on the tank floor only results in a maximum floor temperature near $50^{\circ} \mathrm{C}$. This volume of material is roughly equivalent to 27 processing cycles using a 450 gallon bed (unground basis).

- Mixtures of ground CST with sludge or loaded MST do not promote significantly higher maximum floor temperature than are predicted for CST alone.

- A homogenous mixture of 6000 gallons of ground CST with 1000 gallons of loaded MST distributed as a flat layer only results in a maximum floor temperature near 50 ${ }^{\circ} \mathrm{C}$.

- A homogenous mixture of 6000 gallons of ground CST with 10,000 gallons of sludge distributed as a flat layer only results in a maximum floor temperature near $40{ }^{\circ} \mathrm{C}$. 


\subsection{REFERENCES}

1. King, W. D., Duffey, C. E., Malene. S. H., 2004. "Determination of Cesium $\left(\mathrm{Cs}^{+}\right)$ Adsorption Kinetics and Equilibrium Isotherms from Hanford Waste Simulants using Resorcinol-Formaldehyde Resins (U)" WSRC-TR-2003-00574, Rev. 0, March 2004.

2. S. Y. Lee, "Heat Transfer Analysis for Fixed CST and RF columns, Savannah River National Laboratory, WSRC-STI-2007-00345, October 2007.

3. W. D. King, F. G. Smith, S. Y. Lee, D. J. McCabe, and T. Punch, "Comparisons of RF and CST Media for Cesium Removal by In-Tank Column Processing", $15^{\text {th }}$ Symposium on Separation Science and Technology, Gatlinburg, TN, October 2007.

4. F. G. Smith, III, S. Y. Lee, W. D. King, D. J. McCabe, "Comparisons of Crystalline Silicotitanate and Resorcinol Formaldehyde Media for Cesium Removal by Intank Column Processing", Separation Science and Technology, vol. 43, pp. 2929, 2008.

5. C. M. Cole, "CSTF Corrosion Control Program: Program Description Document", WSRC-TR-2003-00327, Rev. 4, December 2007.

6. S. Y. Lee, "Task Plan For Thermal Modeling of Ion Exchange Columns with Spherical RF Resin", Savannah River National Laboratory, SRNL-TR-200900270, Rev. 0, July 2009.

7. B. B. Spencer, H. Wang, K. K. Anderson, "Thermal Conductivity of IONSIVIE911TM Crystalline Silicotitanate and Savannah River Waste Simulant Solutions",ORNL/TM-2000/285, Oak Ridge National Laboratory, TN, 2000.

8. F. G. Smith, III, "Modeling of Ion-Exchange for Cesium Removal from Dissolved Saltcake in SRS Tanks 1-3, 37 and 41", WSRC-STI-2007-00315, June 2007.

9. W. M. Kays and M. E. Crawford, Convective Heat and Mass Transfer, Second Edition, McGraw-Hill Book Company, New York (1980).

10. S. Y. Lee, "Three-Dimensional Thermal Performance Analysis for HLW Disposal Gallery", SRNL technical report, WFO-08-014-1, July 27, 2009.

11. S. Y. Lee, "Two-Phase Flow and Heat transfer in Porous Media", MS Thesis, Massachusetts Inst. of Technology, 1983.

12. C. Y. Warner and V. S. Arpaci, "An Experimental Investigation of Turbulent Natural Convection in Air at Low Pressure along a Vertical Heated Flat Plate", International Journal of Heat and Mass Transfer, Vol. 11, pp. 397-406 (1968).

13. F. W. Dittus and L. M. E. Boelter, Engineering Publication vol. 2, pp. 443, University of California (1930).

14. Fluent ${ }^{T M}$, Ansys, Inc., 2008.

15. R. Krupiczka, "Analysis of Thermal Conductivity in Granular Materials", International Chemical Engineering, Vol. 7, No. 1, pp. 122-144 (1967).

16. S. E. Aleman, G. P. Flach, L. L. Hamm, S. Y. Lee, and F. G. Smith, III, 1993, "FLOWTRAN-TF Code Software Design (U)", WSRC-TR-92-532, Savannah River National Laboratory, Westinghouse Savannah River Company, February 1993.

17. V. E. Schrock, C. H. Wang, S. Revankar, L. H. Wei, and S. Y. Lee, "Steam-Water Flooding in Debris Beds and Its Role in Dryout", Electric Power Research Institute, EPRI NP-3858, March 1985.

18. A. B. Yu and N. Standish, "Estimation of the Porosity of Particle Mixtures by a Linear-Mixture Packing Model", Ind. Eng. Chem., Vol. 30, pp. 1372 - 1386, 1991. 
19. J. P. Holman, Heat Transfer, $4^{\text {th }}$ edition, McGraw-Hill Book Company, New York (1976).

20. R. H. Perry and C. H. Chilton, Chemical Engineers' Handbook, McGraw-Hill Book Company, New York (1973).

21. R. G. Baxter, "Defense Waste Processing Facility Wasteform and Canister Description", Dupont Company document, DP-1606, Rev. 2 (1988). 